\title{
Electrochemical and Microstructural Analysis of Solid Oxide Fuel Cell Electrodes
}

\author{
Mingjia Zhi \\ West Virginia University
}

Follow this and additional works at: https://researchrepository.wvu.edu/etd

\section{Recommended Citation}

Zhi, Mingjia, "Electrochemical and Microstructural Analysis of Solid Oxide Fuel Cell Electrodes" (2011). Graduate Theses, Dissertations, and Problem Reports. 4823.

https://researchrepository.wvu.edu/etd/4823

This Dissertation is protected by copyright and/or related rights. It has been brought to you by the The Research Repository @ WVU with permission from the rights-holder(s). You are free to use this Dissertation in any way that is permitted by the copyright and related rights legislation that applies to your use. For other uses you must obtain permission from the rights-holder(s) directly, unless additional rights are indicated by a Creative Commons license in the record and/ or on the work itself. This Dissertation has been accepted for inclusion in WVU Graduate Theses, Dissertations, and Problem Reports collection by an authorized administrator of The Research Repository @ WVU.

For more information, please contact researchrepository@mail.wvu.edu. 


\title{
Electrochemical and Microstructural Analysis of Solid Oxide Fuel Cell Electrodes
}

\author{
Mingjia Zhi
}

\author{
Dissertation submitted to the \\ College of Engineering and Mineral Resources \\ at West Virginia University \\ in partial fulfillment of the requirements \\ for the degree of
}

Doctor of Philosophy

in

Mechanical Engineering

Nianqiang Wu, Ph.D., Chair

Ismail Celik, Ph.D.,

Harry Finklea, Ph.D.,

Randall Gemmen, Ph.D.,

Bruce Kang, Ph.D.,

Ayyakkannu Manivannan, Ph.D.,

Edward Sabolsky, Ph.D.,

Department of Mechanical and Aerospace Engineering

Morgantown, West Virginia

2011

Keywords: Solid Oxide Fuel Cell; Electrodes; Electrochemistry; Microstructure

Copyright 2011 Mingjia Zhi 


\section{ABSTRACT \\ Electrochemical and Microstructural Analysis of Solid Oxide Fuel Cell Electrodes}

\section{Mingjia Zhi}

Fuel cells offer several advantages over conventional routines of power generation, such as substantially higher conversion efficiency, modular construction, minimal sitting restriction, and much lower production of pollutants. Solid oxide fuel cell (SOFC), in principle, can utilize all kinds of combustion fuels including coal derived syngas (CSG). The U.S. Department of Energy is currently working on coupling coal gasification and SOFC to form Integrated Gasification Fuel Cell (IGFC) systems. Such IGFC systems will enable the clean, efficient and cost-effective use of coal -the nation's most abundant fossil fuel.

However several issues need to be considered before SOFC can be really commercialized. The anode of SOFC can interact with the trace impurities in CSG such as arsenic, phosphorous, chlorine etc, which leads severe degradation of the cell performance. The operation temperature of current SOFC is also high $\left(>800{ }^{\circ} \mathrm{C}\right)$, which increases the system cost. Hence, further study of both the anode and cathode is necessary in order to develop high performance, long serving time SOFC for IGFC power plant.

One of the aims of this project is to investigate the degradation mechanisms of the $\mathrm{Ni}$ YSZ (yttria stabilized zirconia) anode in $\mathrm{PH}_{3}$ contained coal syngas. Materials microstructure change and electrochemical performance degradation were studied synchronously. Key factors such as the operating temperature, the impurity concentration as well as the cell operation conditions were investigated, which is essential to understanding the degradation behavior of SOFC. It has been found that $\mathrm{Ni}$ phosphate is the product of reaction between $\mathrm{Ni}$ and $\mathrm{PH}_{3}$, leading to the loss of both the electrochemical activity and the electron conductivity of the anode. In addition, surface reconstruction is ascribed to Ni-P diffusion to the anode surface. Impedance spectra are fitted with the equivalent circuits to interpret the physical and chemical processes during degradation. The impedance analysis has shown that the mass diffusion resistance increases faster than the charge transfer resistance. The anode degradation is accelerated by increase in the operating temperature, the $\mathrm{PH}_{3}$ concentration and the electrical bias.

On the other side, novel metal oxide nanofibers have been developed as the SOFC cathode materials using the electrospinning method in order to enhance the electrochemical performance of SOFCs. A high performance cathode has been developed by infiltrating lanthanum strontium manganite (LSM) into the porous yttria-stabilized zirconia (YSZ) nanofiber backbone, which has showed superior oxygen reduction activity as compared to a conventional powder cathode. The power density of single unit of SOFC with LSCF nanofibers as the cathode can reach $1.07 \mathrm{~W} / \mathrm{cm}^{2}$ at $750{ }^{\circ} \mathrm{C}$. Such cathode architecture could bring the operation temperature of SOFC down to the intermediate temperature range, which will significantly reduce the cost of whole SOFC system. 


\section{Acknowledgement}

I would like to dedicate this dissertation to my parents, for their constant support during my study.

I am sincerely grateful to Dr Nianqiang Wu for his guidance of the whole research project. He has been a great support throughout my doctorate program in both academic and extracurricular activities. I am glad to have the opportunity to finish the doctoral degree under his supervision.

I would also thank all my committee members for their support and guidance on my research.

Special thanks are due to all the members of Dr Nianqiang Wu's research group in WVU. I also appreciate the help from colleagues in WVU NIFT and NETL fuel cell group.

The research work is financially sponsored by the US Department of Energy Office of Basic Energy Sciences, National Energy Technology Laboratory, WV State EPSCoR Office and West Virginia University under the DOE EPSCoR Program (DE-FG02-06ER46299) and National Energy Technology Laboratory's on-going research in fuel cell project (41817M2187/41817M2100) under the Research and Development Solutions, LLC (RDS) contract DE-AC26-04NT41817. 


\section{Table of Contents}

Chapter 1: Introduction.....................................................1

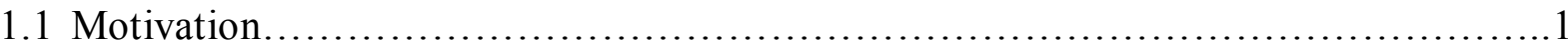

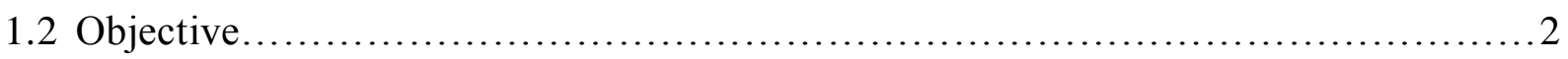

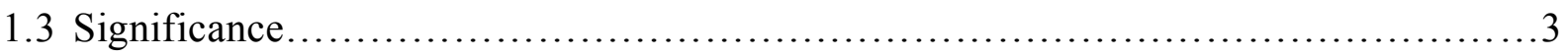

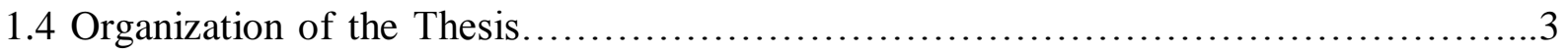

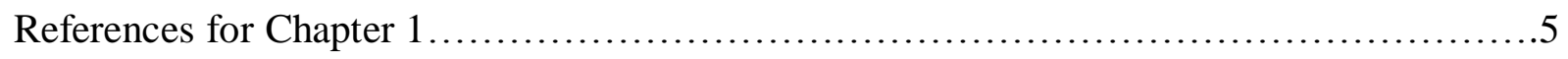

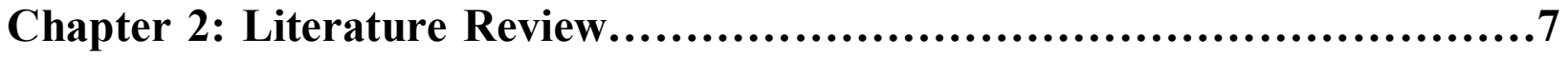

2.1 Introduction to Solid Oxide Fuel Cells..........................................

2.2 Trance Impurities in Coal Derived Syngas....................................... 11

2.3 Effects of Impurities on SOFC Anode........................................ 14

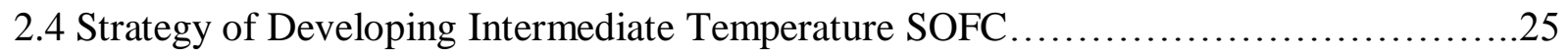

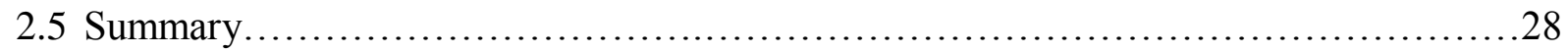

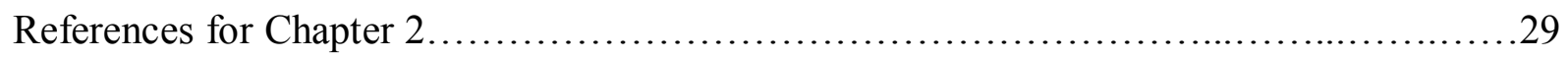

Chapter 3: Degradation Behavior and Mechanisms of Ni-YSZ Anode in $\mathrm{PH}_{3}$

Contained Coal Syngas..................................................35

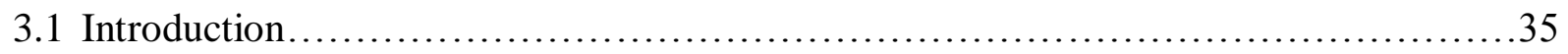

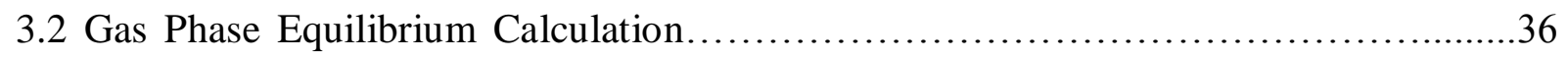

3.3 Degradation of Ni-YSZ Anode in $\mathrm{PH}_{3}$ Contained Coal Syngas: Effect of the Electrical

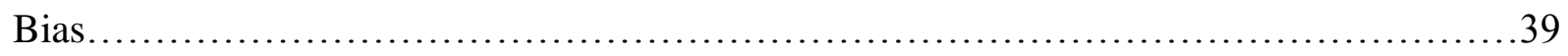

3.3.1 Experimental Methods..................................................39

3.3.2 Result and Discussion.............................................40 
3.3.2.1 Electrochemical Measurement..........................................40

3.3.2.2 Microstructural Analysis.............................................45

3.4 Degradation of Ni-YSZ Anode in $\mathrm{PH}_{3}$ Contained Coal Syngas: Effect of the Temperature

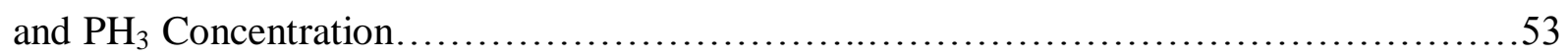

3.4.1 Experimental Methods..........................................................53

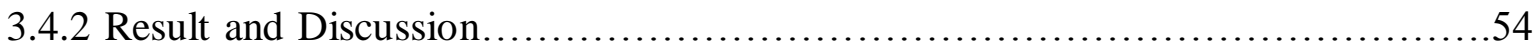

3.4.2.1 Electrochemical Measurement...........................................54

3.4.2.2 Microstructural Analysis............................................58

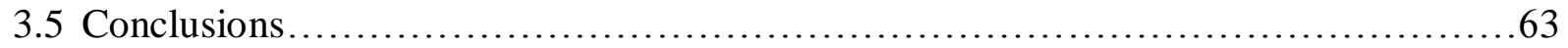

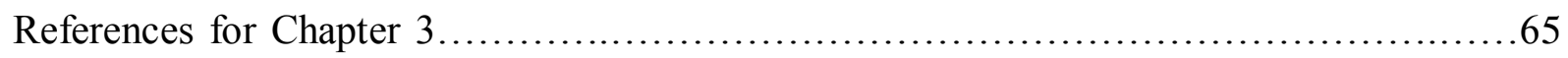

Chapter 4 Synthesis of Nanofibers for SOFC Cathode Application............67

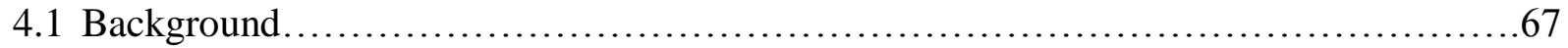

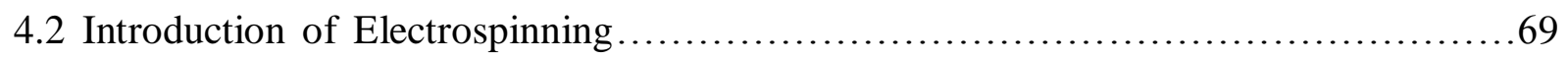

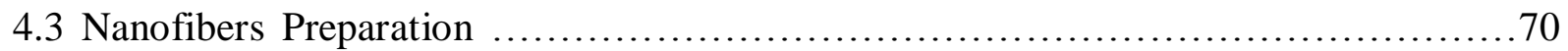

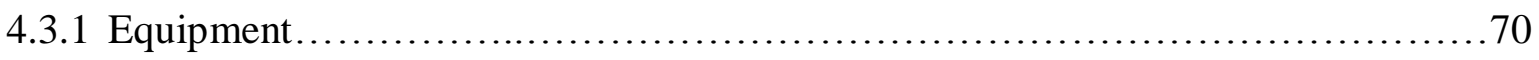

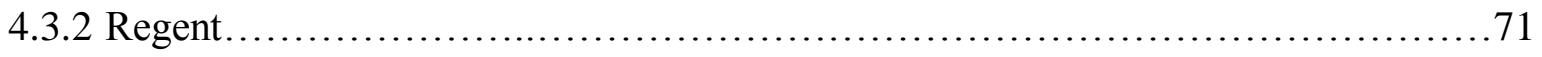

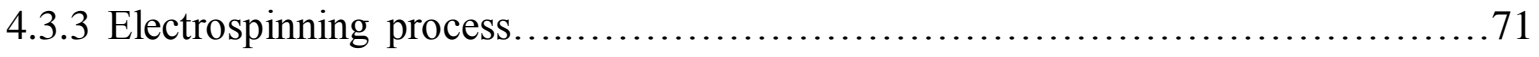

4.3.4 Characterization method................................................... 71

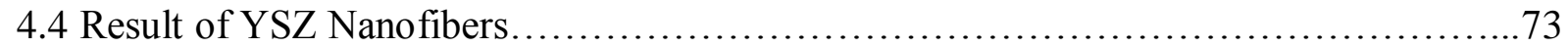

4.5 Result of LSM Nanofibers........................................................... 77

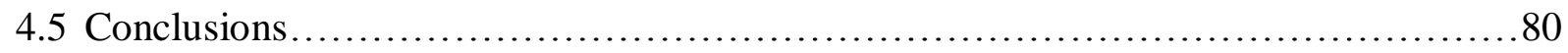

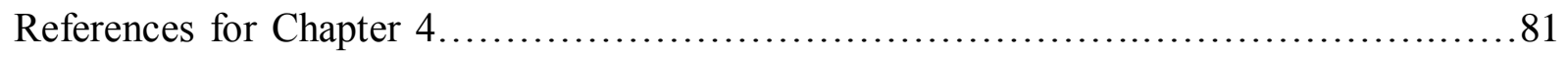




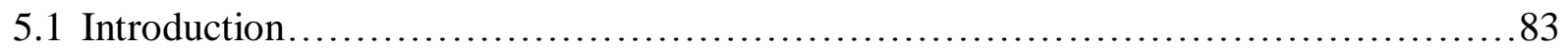

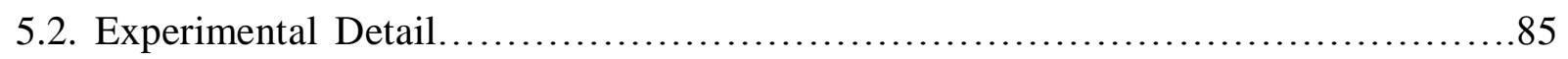

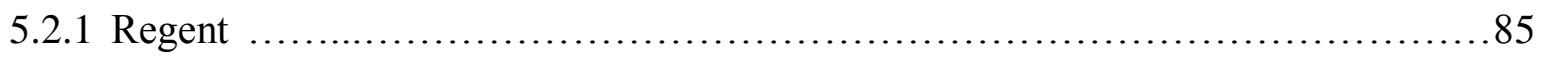

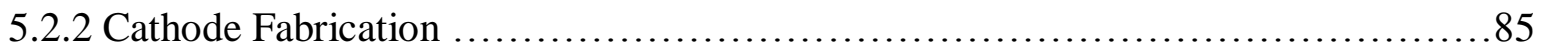

5.2.3 Electrochemical Characterization .................................................86

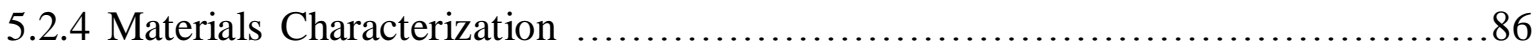

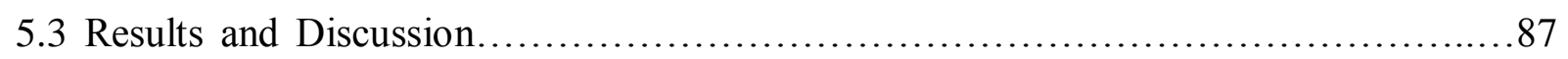

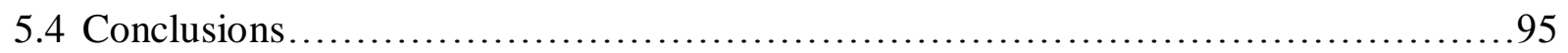

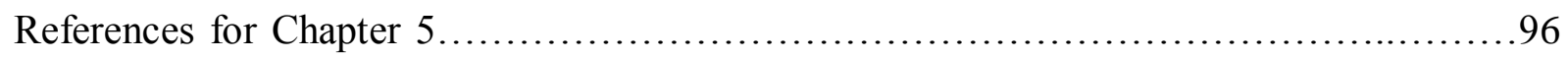

Chapter 6 Characterization of the LSCF Nanofibers Unit Cell.................98

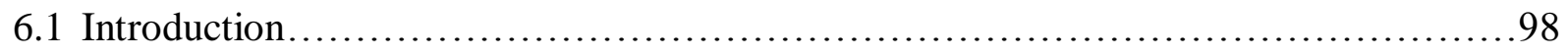

6.2. Experimental Detail....................................................... 99

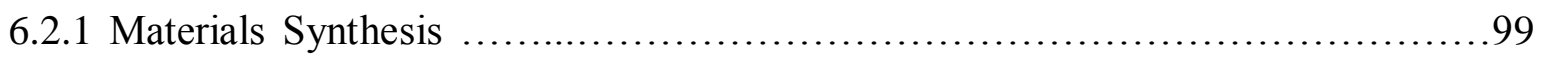

6.2.2 Fuel Cell Fabrication and Testing ...........................................99

6.2.3 Materials Characterization ................................................... 100

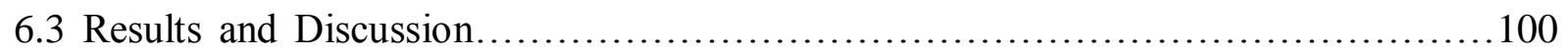

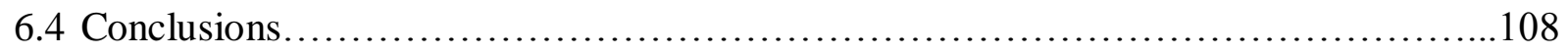

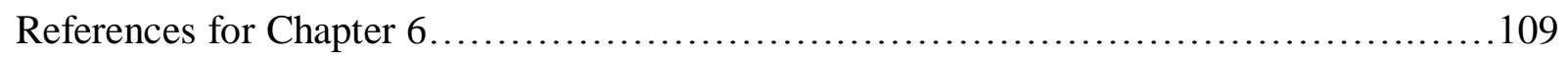

\section{Chapter 7 Conclusions and Future Work .................................111}

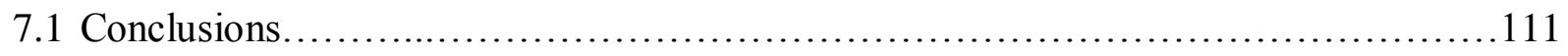

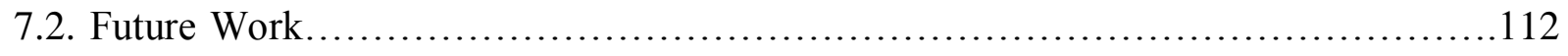

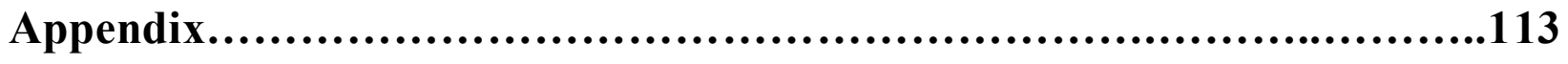




\section{List of Tables}

Table 2.1 Comparison summary of the major fuel cells.............................

Table 2.2 Typical coal syngas composition....................................11

Table 2.3 Trace species and concentration in coal syngas............................ 12

Table 2.4 A list of different impurities chemical form changing at different temperatures....13

Table 2.5 List of the investigated trance impurities and their degradation effects to Ni-YSZ

Table 2.6 Basic properties of common SOFC cathode materials.........................26

Table 3.1 $\mathrm{P}_{2} \mathrm{O}_{3}$ and $\mathrm{PH}_{3}$ concentration at given experimental conditions...................38

Table 3.2 Coal syngas composition used in experiments...........................40

Table 3.3 Parameters of the equivalent circuit at the different conditions at $900{ }^{\circ} \mathrm{C} \ldots \ldots \ldots . .45$

Table 5.1 Polarization resistance of different cathodes.............................91 


\section{List of Figures}

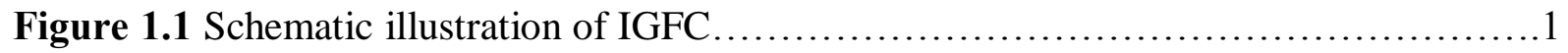

Figure 2.1 Power output versus effiency of SOFC compared with other commercial technologies.................................................................

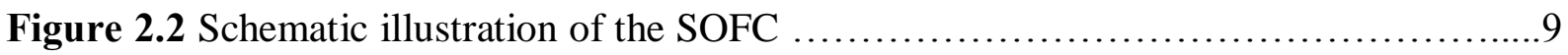

Figure 2.3 (a) the porous anode structure and (b) the schematic map of the triple phase

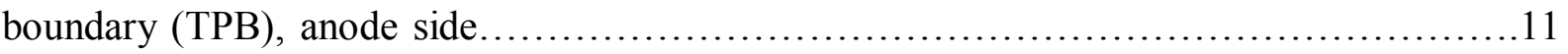

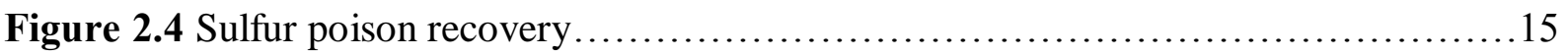

Figure 2.5 Typical I-V curve of SOFC operated at $800^{\circ} \mathrm{C}$, the polarization loss is separated

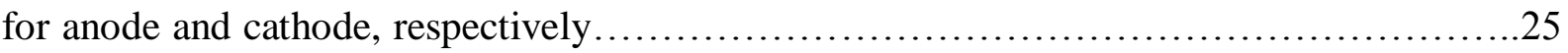

Figure 2.6 Different oxygen reduction pathways for (a) LSM/YSZ and (b) MIEC cathode..27 Figure 3.1 Research strategy of investigating the degradation behavior of Ni-YSZ anode in

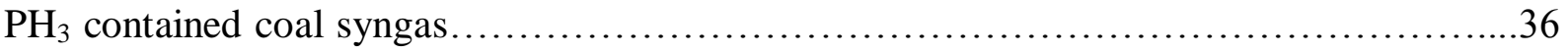
Figure 3.2 $\mathrm{P}_{2} \mathrm{O}_{3}$ and $\mathrm{PH}_{3}$ mole fractions at equilibrium, solid line represents $\mathrm{P}_{2} \mathrm{O}_{3}$ and dash line represents $\mathrm{PH}_{3}$ 38

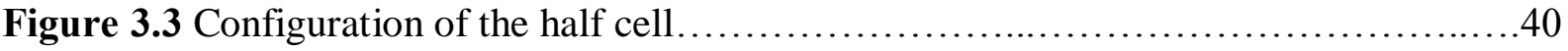

Figure 3.4 Effect of the fuel gas on the DC current (driven by the DC bias of $0.7 \mathrm{~V}$ )........41

Figure 3.5 Nyquist plot of impedance obtained from the half cell at $900^{\circ} \mathrm{C}$; (a) under the open circuit condition; (b) at $+0.7 \mathrm{~V}$ potential applied between the working electrode and the counter electrode.

Figure 3.6 Equivalent circuit model of the impedance spectra. .43 
Figure 3.7 Charge transfer resistance $\left(R_{p}\right)$ and diffusion resistance $\left(R_{w}\right)$ derived from the impedance spectra obtained at $900^{\circ} \mathrm{C}$. .45

Figure 3.8 SEM images of the Ni-YSZ working electrode surface; (a) the electrode after exposure to the clean syngas (clean cell); (b) the electrode after exposure to the $\mathrm{PH}_{3}$ containing syngas at the open circuit (c) the electrode after exposure to the $\mathrm{PH}_{3}$-containing syngas at the applied DC bias of $0.7 \mathrm{~V}$.....

Figure 3.9 XRD patterns of the Ni-YSZ working electrode; (a) the electrode after exposure to the clean syngas (clean cell); (b) the electrode after exposure to the $\mathrm{PH}_{3}$-containing syngas at the open circuit (open circuit cell); (c) the electrode after exposure to the $\mathrm{PH}_{3}$-containing syngas at the applied DC bias of $0.7 \mathrm{~V}$ (loaded cell) 48

Figure 3.10 Survey scan of the XPS spectra obtained from the Ni-YSZ working electrode under different experimental conditions; (i) the electrode after exposure to the clean syngas (clean cell), (ii) the electrode after exposure to the $\mathrm{PH}_{3}$-containing syngas at the open circuit (open circuit cell), and (iii) the electrode after exposure to the $\mathrm{PH}_{3}$-containing syngas at the

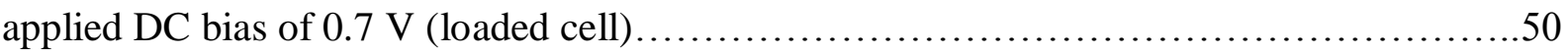

Figure 3.11 (a) XPS spectrum of the P 2p core level; (b) XPS spectrum of the Ni 2p core level; (c) XPS spectrum of the Zr 3d core level...

Figure 3.12 Nyquist plots of the impedance spectra taken from the half cell in the syngas

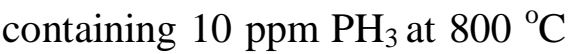
.55

Figure 3.13 Normalized charge transfer resistance $\left(R_{p}\right)$ and mass transfer resistance $\left(R_{w}\right)$ as function of the temperature after $48 \mathrm{~h}$ of exposure (a) in $5 \mathrm{ppm} \mathrm{PH}_{3}$ and (b) in $10 \mathrm{ppm}$

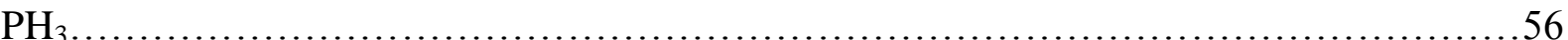

Figure 3.14 Tafel plots of the Ni-YSZ electrode $\left(800{ }^{\circ} \mathrm{C}, 10 \mathrm{ppm} \mathrm{PH}_{3}\right) \ldots \ldots \ldots \ldots \ldots \ldots . . \ldots 7$ 
Figure 3.15 Illustration of the Tafel fitting.

Figure 3.16 SEM images of the Ni/YSZ electrode (a) surface morphology after $24 \mathrm{~h}$ of exposure to the clean syngas at $900^{\circ} \mathrm{C}$, (b) surface morphology after $48 \mathrm{~h}$ of exposure to 10 ppm $\mathrm{PH}_{3}$ at $900^{\circ} \mathrm{C}$, (c) cross section morphology after $24 \mathrm{~h}$ of exposure to the

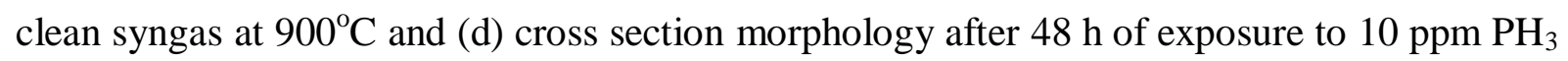
at $900^{\circ} \mathrm{C}$.

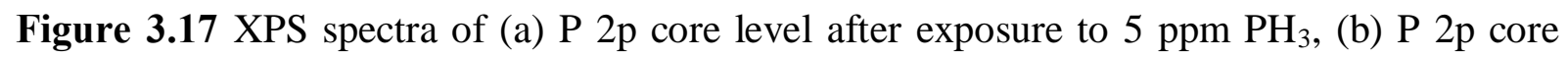

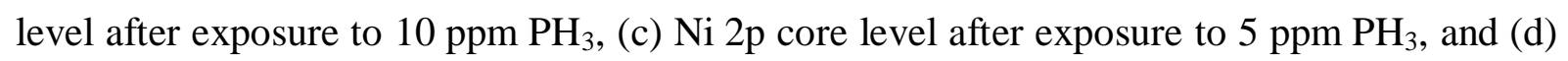
$\mathrm{Zr} 3 \mathrm{~d}$ core level after exposure to $5{\mathrm{ppm} \mathrm{PH}_{3}}$

Figure 3.18 The XPS peak intensity ratio of $\mathrm{P} 2 \mathrm{p}$ to $\mathrm{Ni} 2 \mathrm{p}$.

Figure 3.19 Two dimensional chemical potential diagram for the Ni-P-O system in a log $\{\mathrm{p}(\mathrm{O} 2) / \mathrm{atm}\}$ vs. $\log \mathrm{a}(\mathrm{P})$ plot at $1073 \mathrm{~K}$

Figure 4.1 Schematic of the electrospinning process

Figure 4.2 Flowchart of the nanofiber preparing process. .70

Figure 4.3 SEM image of the as spun YSZ nanofibers. .72

Figure 4.4 Picture of a 4 inch diameter sample collector after electrospinning experiment, the white sheet is the YSZ raw fiber mat.... .73

Figure 4.5 SEM image of the YSZ nanofibers obtained after $600^{\circ} \mathrm{C}$ heating .73

Figure 4.6 SEM image of the YSZ nanofibers after $1000^{\circ} \mathrm{C}$ heating for 3 hours, from (a) to (c) are low to high magnifications. .74

Figure 4.7 XRD pattern of the YSZ nanofibers obtained after different temperature heat

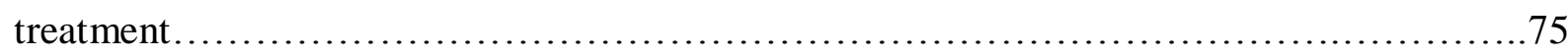

Figure 4.8 Mechanism of nanofiber formation. .76 
Figure 4.9 Activation energy plot for the nanograins in the YSZ nanofiber. .76

Figure 4.10 SEM image of LSM raw nanofibers. .77

Figure 4.11 SEM images of the LSM nanofibers formed at $600^{\circ} \mathrm{C}$, (a) low magnification and (b) high magnification .78

Figure 4.12 XRD pattern of the YSZ nanofibers obtained after different temperature heat treatment.

Figure 4.13 SEM images of the LSM nanofibers after $1000^{\circ} \mathrm{C}$ annealing, (a) low magnification and (b) high magnification. .79

Figure 5.1 (a) Process of the electrode fabrication using infiltration method and (b) ideal cathode microstructure 83

Figure 5.2 Fabricating process of the LSM /YSZ nanofibers composite cathode .86

Figure 5.3 The configuration of the three-electrode half cell .86

Figure 5.4 SEM images of the cathode; (a) YSZ nanofiber scaffold before infiltration, (b) top surface of LSM50/YSZ composite cathode after infiltration and calcination at $650{ }^{\circ} \mathrm{C}$, (c) a close view of the top surface of the LSM50/YSZ composite cathode, and (d) cross-section of the LSM50/YSZ composite cathode. .88

Figure 5.5 EDX analysis of the LSM50/YSZ cathode; Spot 1 is pointed on the nanofiber, and Spot 2 is obtained from the membrane between the nanofibers. .89 Figure 5.6 XRD patterns of the YSZ nanofiber scaffold and the LSM50/YSZ nanofiber composite cathode 90

Figure 5.7 Nyquist plots of impedance taken from the LSM50/YSZ composite cathode in which the LSM nanoparticles are supported on the YSZ nanofiber scaffold1 .91 
Figure 5.8 Polarization resistance as a function of the LSM content in the YSZ/LSM composite cathode at different temperatures....

Figure 5.9 SEM images of the different cathodes: (a) LSM25/YSZ and (b)

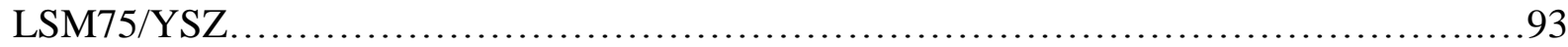

Figure 5.10 A schematic used to estimate the TPB length in the cathode..................95

Figure 6.1 (a) and (b) SEM image of the LSCF nanofibers fired at $800^{\circ} \mathrm{C}$, (c) corresponding XRD pattern and (d) the nanofibers size distribution.

Figure 6.2 (a) TEM image of a single LSCF nanofiber and corresponding SAED pattern (insert) and (b) EDX spectra taken from the nanofiber, the $\mathrm{Cu}$ signal came from $\mathrm{Cu}$ grid for dispersing sample.

Figure 6.3: SEM images of the LSCF nanofibers cathode cell after testing, (a) the surface morphology of the cathode and (b) the cross section of the cell........................ 103

Figure 6.4: The V-I curves of the LSCFNF cell at different temperatures............... 103

Figure 6.5 The XPS O1s core level of the LSCF nanofibers and nanopowders.... .105

Figure 6.6 The V-I curve of the LSCFGDC20 (a) and LSCFGDC50 (b) cells at different temperature .106

Figure 6.7 SEM images of the surface morphology of the LSCF/GDC cathodes, (a) and (b): LSCF20GDC cathode; (c) and (d): LSCF50GDC cathode. 107

Figure 6.8 XRD patterns of the fuel cells taken on the cathode side after testing. 108 


\section{Chapter 1: Introduction}

\subsection{Motivation:}

Fuel cells offer several advantages over conventional routines of power generation, such as substantially higher conversion efficiency, modular construction, minimal sitting restriction, potential for co-generation, and much lower production of pollutants [1-9]. Solid oxide fuel cell (SOFC), in principle, can utilize most kinds of combustion fuels including $\mathrm{H}_{2}$ [10-13], natural gas [14], oil [15-16], biogas [17], and coal derived syngas (CSG) [18-20]. In addition, SOFC are capable of gas reforming process, which is able to produce $\mathrm{H}_{2}$ fuel [21]. The U.S. Department of Energy is currently working on coupling coal gasification and SOFC to form Integrated Gasification Fuel Cell (IGFC) systems. Such IGFC systems will enable the clean, efficient and costeffective use of coal -the nation's most abundant fossil fuel. Figure 1.1 is a schematic map of IGFC [22], in which the efficiency increasing and $\mathrm{CO}_{2}$ emission reduction can be achieved.

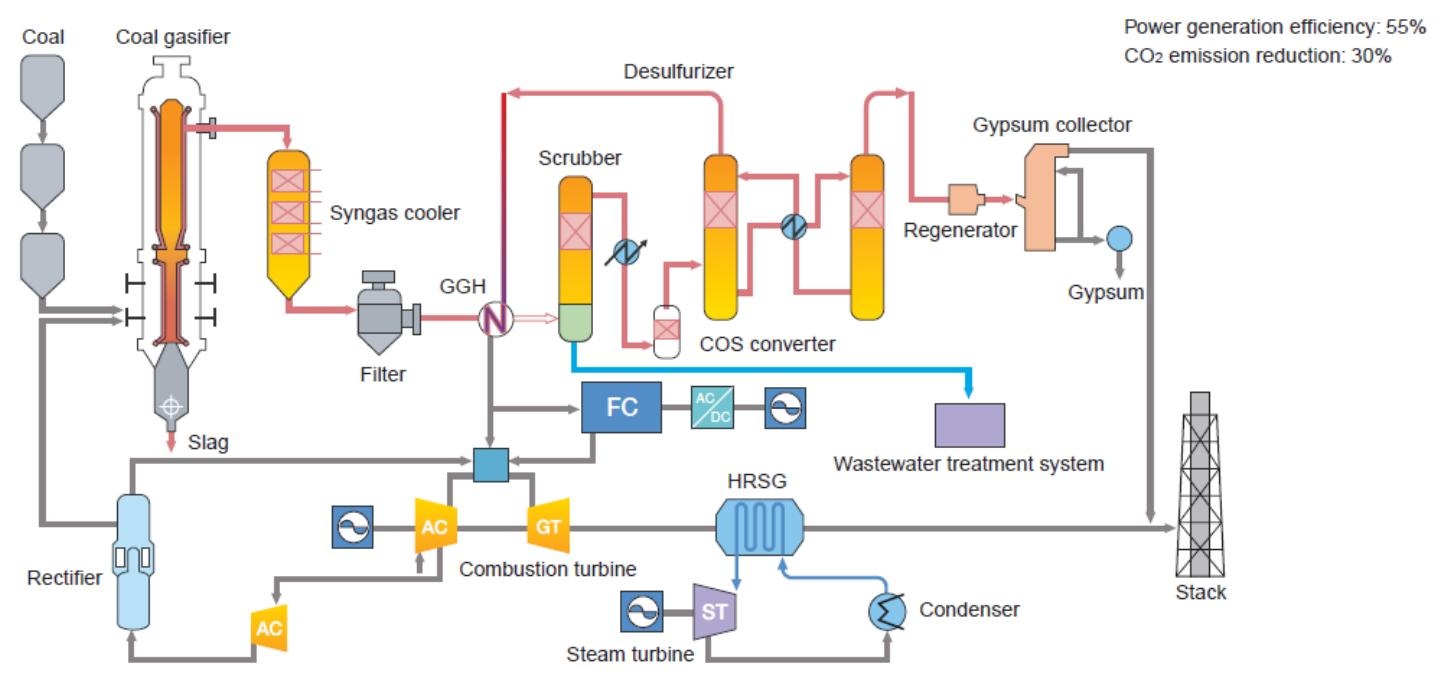

Figure 1.1 Schematic illustration of IGFC [22] 
Although owing promising future, several issues need to be considered before SOFC can really compete with other alternative energy systems. Some of the challenges include:

1. The interaction between the SOFC anode materials and the trance impurities in coal syngas. Coal-derived syngas that is fed into the SOFC in the IGFC system contains various impurities such as phosphorus, arsenic, zinc, sulfur, mercury, selenium, vanadium etc. [23-24]. The cost of completely cleaning up such impurities is high. When the SOFC anode made of Ni-YSZ (yttria stabilized zirconia) is operated in such impurities, it is subject to severe degradation due to attacking by these trace impurity species, which is well known in recent study [25]. It is essential to estimate the tolerance limit of SOFC toward these impurities and to understand the degradation mechanism in order to develop new anode materials that can resist these impurities.

2. The operation temperature of SOFC is high. Normally SOFC is running above $900^{\circ} \mathrm{C}$, including Siemens's recent SOFC hybrid power generation system demonstration [26]. Although such high operation temperatures could favor the chemical reaction and transport kinetics, the SOFC cost increases dramatically due to the severe environment that the system would be subject to. A lower operating temperature would allow the use of oxidation-resistant metallic alloys as interconnect materials in SOFC, and would permit the use of inexpensive heat-exchangers. It would also increase the cell durability, extend the service life, and permit more frequent temperature and performance cycling, and shorten startup times [27, 28]. A brief literature review (in Chapter 2) also reveals that the degradation of anode with some of the trance impurities could be suppressed at lower temperature. Therefore developing intermediate temperature $\left(600^{\circ} \mathrm{C}-750^{\circ} \mathrm{C}\right) \mathrm{SOFC}$ could bring huge economic and technology benefits to the whole SOFC research community.

\subsection{Objective:}

The overall objective of this dissertation is the characterization of the SOFC electrodes (both anode and cathode) using both electrochemical and microstructural analysis methods. 
The first specific aim is to gain fundamental understanding of the degradation behavior and mechanism of the Ni-YSZ anode operated in the phosphorus-containing coal-derived syngas by using electrochemical measurement, materials characterization as well as thermodynamics calculations. A comprehensive study on the different parameters such as temperatures, impurity concentration, and electrical bias will be carried out. A correction between the electrochemical performance and the materials microstructure will be presented.

The second specific aim is developing intermediate temperature SOFC based on the observation from the first part of work. The research strategy will be focused on optimizing the cathode architectures by using one dimension (1-D) nanofibers. A reliable electrospinning method for producing such nanofibers is developed. The microstructures of such cathodes will be characterized and the electrochemical performance will be demonstrated.

\subsection{Significance:}

Coal is one of the richest hydrocarbon fuels in the United States and in the world. Direct utilization of CSG as the fuel in SOFC obviously brings a great economic benefit. However, the commonly used Ni-YSZ anode is subject to performance degradation when it is applied to the syngas environment. We will clarify the degradation behavior and fundamental degradation mechanism of the SOFC anodes operated in the syngas. The proposed research will provide researchers and industry with the data that is the prerequisite for formulating a solution to the problem.

In addition, our unique design of the cathode structure will greatly enhance the oxygen reduction properties of the cathode by improving the mass and charge transport capability. The proposed research initiates new concepts of cathode microstructure and will evaluate critical performance criteria identified by SECA (Solid State Energy Conversion Alliance) and industry. Potentially beneficial microstructures developed through the efforts described here will be targeted for transfer to SECA industrial partners. 


\subsection{Organization of the Thesis:}

This dissertation consists of 7 chapters including the introduction.

In Chapter 2 a detailed literature review will be given to address the current main challenges on the SOFC anode and cathode. On the anode side a review of the investigated degradation behavior of Ni-YSZ anode of the trace impurities contained in coal syngas is provided, then on the cathode the effort of optimizing the materials and microstructures are emphasized. Based on this review, a strategy of by lowing SOFC operation temperature to minimize the degradation impact is proposed. An improvement of the cathode then becomes the top priority in order to fulfill this goal.

In Charter 3 a detailed survey of Ni-YSZ anode degradation behavior in $\mathrm{PH}_{3}$ impurity containing coal syngas is provided, materials structure change and electrochemical performance degradation are studied synchronously in order to build the internal link between these basic parameters. Some main factors which are essential to the degradation behavior are investigated, such as temperature, impurity concentration as well as the cell operation conditions.

Chapter 4 introduces our electrospinning method to fabricate ceramic nanofibers for cathode application. The nanofibers crystalline structure and their thermal stability are studied.

In Chapter 5 an example is provided to show how the nanofibers could improve the conventional cathode performance by using such novel architecture. The relationship between the microstructure and half cell electrochemical performance is given.

In Chapter 6 a nanofiber cathode unit cell performance is provided and demonstrates that our strategy could bring the operation temperature of SOFC down to intermediate range. Such results not only show the cell performance enhancement but will also improve the anode impurity tolerance potentially.

Chapter 7 summarizes the main findings of this study, giving the itemized conclusions and the outlook for future research. 


\section{References for Chapter 1:}

[1] K. Hassmann, Fuel Cells, 1, 2001, 78

[2] F. Jurado, Fuel Cells, 4, 2004, 378

[3] E .Riensche, U Stimming and G. Unverzagt, J.Power.Sources, 73, 1998, 251

[4] F. Coutelieris, S. Douvartzides, S. Song and P. Tsiakaras, Inter. J. Green. Energy, 1, 2004, 241

[5] Cummins Power Generation, 3rd SECS annual workshop, 2002, Washington, DC

[6] S. McIntosh and R. J. Gorte, Chem. Rev., 104, 2004, 4845

[7] S.C. Singhal, Solid State Ionics, 135, 2000, 305

[8] S. P. Jiang and S. H. Chan, J. Mater. Sci., 39, 2004, 4405

[9] W.Vielstich, A. Hubert, M. Gasteiger and A. Lamm, Handbook of Fuel CellsFundamentals, Technology and Applications, Chapter 74, Wiley, New York (2003)

[10] H. Koide, Y. Someya, T. Yoshida and T. Maruyama, Solid State Ionics, 132, 2000, 253

[11] J. H. Jiang and J. H. Ryu, Ionics, 6, 2000, 86

[12] S. Primdahl and M. Mogensen, J. Electrochem. Soc, 144, 1997, 3408

[13] A. Weber, B. Sauer, A.C. Muller, D. Herbstritt and E. Ivers-Tiffee, Solid State Ionics, $152-153,2002,543$

[14] J. Liu and S. A. Barnett, Solid State Ionics, 158, 2003, 11

[15] Z. L. Zhan and S, A. Barnet, Science, 308, 2003, 844

[16] Z. F. Zhou, C. Gallo, M. B. Pague, H. Schobert and S. N. Lvov, J .Power.Sources, $133,2004,181$

[17] J. Staniforth and R. M. Ormerod, Ionics, 9, 2003, 336 
[18] E. H. Pacheco, M. D. Mann, P. N. Hutton, D. Singh and K.E. Martin, Inter. J. Hydrogen Energy, 30, 2005, 1221

[19] J. P. Trembly, A.I. Marquez, T.R. Ohrn and D. J. Bayless, J. Power Sources, 158, 2006, 2638

[20] R. Suwanwarangkul, E. Croiset, M. W. Fowler, P.L. Douglas, E. Entchev and M. A. Douglas, J. Power Sources, 161, 2006, 308

[21] M. C. Williams, J. Strakey and W. Sudoval, J. Power Sources, 159, 2006, 1241

[22] http://www.brain-c-jcoal.info/cctinjapan-files/english/2_3B4.pdf

[23] J. J. Helble, W. Mojtahedi, J. Lyyranen, J. Jokiniemi and E. Kauppinen, Fuel, 75, 1996, 931

[24] S. A. Benson, T. A. Erickson, C. J. Zygarlicke, C. A. O’Keefe, K. A. Katrinak, S. E. Allen, D. J. Hassett and W. B. Hauserman, Proceedings of the Advanced Coal-Fired Power Systems 96 Review Meeting, Morgantown,West Virginia, 1996

[25] F. N. Cayan, M. J. Zhi, S. R. Pakalapati, I. Celik, N. Q. Wu and R. Gemmen, J. Power Sources, 185, 2008, 595

[26] J. A. Ciesar, U. S. Department of Energy Natural Gas/Renewable Energy Hybrids Workshop, 1991, Morgantown, WV

[27] A. J. Jacobson, Chem. Mater., 22, 2010, 660

[28] A. Tarancon, Energy, 2, 2009, 1030 


\section{Chapter 2: Literature Review}

\subsection{Introduction to Solid Oxide Fuel Cells:}

SOFC is a high temperature fuel cell operates at $800^{\circ} \mathrm{C}-1000^{\circ} \mathrm{C}$, which makes it ideal for combined cycle SOFC/turbine applications. Its efficiency may approach 70-80\% combined with turbine system. Single SOFC cell and cell stacks have been realized, and more recently the SOFC/gas turbine hybrid system is demonstrated. The goal of SECA program is to have the cost of SOFC producing unit power to be less than $\$ 400 / \mathrm{KWH}$ in 2011 [1]. There are several advantages by using SOFC for power generation [2]:

High Efficiency: SOFC is operated at high temperatures, which makes it easy to overcome the reaction barriers. The hot exhaust gas can also be further used in the gas turbine and therefore the cogeneration technique can offer $70-80 \%$ efficiency. A comparison of the efficiency versus power output for fuel cell and other power generation methods is shown in Figure 2.1, which confirms SOFC as a superior solution for energy supply, especially at large scale [3].

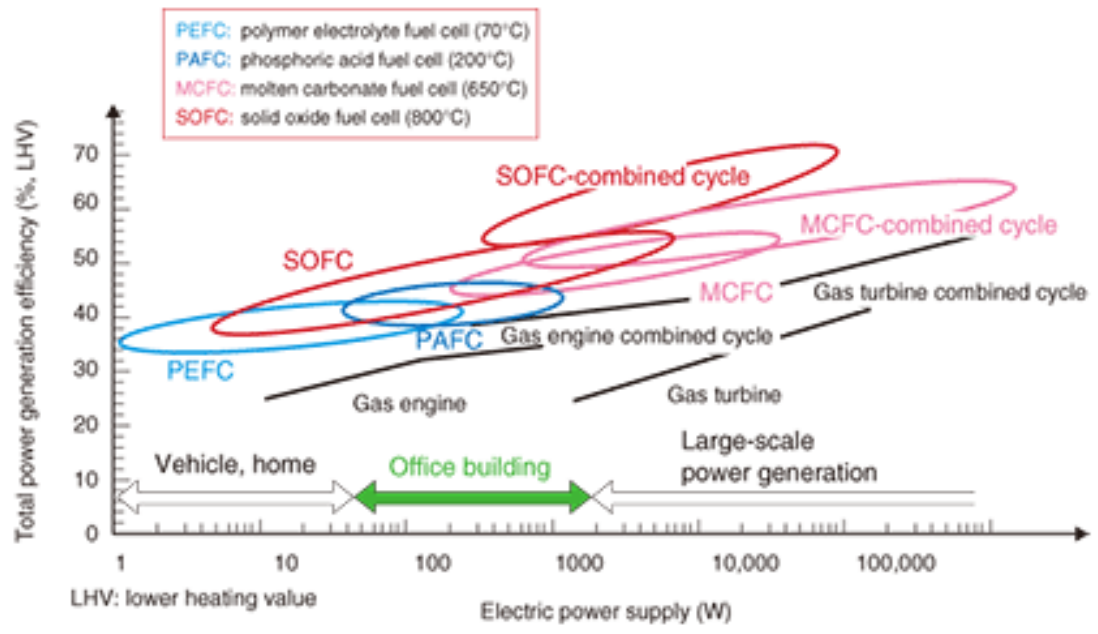

Figure 2.1 Power output versus effiency of SOFC compared with other commercial technologies [3]

Fuel Flexibility: The operation principle ensures SOFC can run many kinds of combustion fuels. This is a great advantage compared with PEM (polymer exchange membrane) fuel cells whose Pt catalyst is sensitive to CO. With higher steam/fuel ratio 
and elevated temperature, SOFC can directly utilize hydrocarbon, or can be used for gas reforming.

Solid Components: SOFC is solid constructed, which makes it easy to install. Unlike AFC (alkaline fuel cell) or MCFC (molten carbonate fuel cell) which employ liquid electrolyte, SOFC can be easily transported or handled during operation.

High Power Density: The power density of normal single SOFC can reach $1 \mathrm{~W} / \mathrm{cm}^{2}$ to $3 \mathrm{~W} / \mathrm{cm}^{2}$ using $\mathrm{H}_{2}$ as fuel [4]. By making stack, SOFC is ideal to serve the high-power application from power plant station to APU (auxiliary power unit). A summary of different major fuel cells comparison is listed in Table 2.1. It can be seen SOFC serves the highest efficiency, most fuel flexibility, and high power generating ability.

\begin{tabular}{|c|c|c|c|c|}
\hline Fuel cell type & $\begin{array}{l}\text { Electrical Efficiency } \\
\qquad \%)\end{array}$ & $\begin{array}{c}\text { Power } \\
\text { density } \\
\left(\mathrm{mW} / \mathrm{cm}^{2}\right)\end{array}$ & $\begin{array}{l}\text { Power } \\
\text { range } \\
(\mathrm{kW})\end{array}$ & $\begin{array}{c}\mathrm{CO} \\
\text { tolerance }\end{array}$ \\
\hline $\begin{array}{c}\text { PAFC (Phosphoric acid } \\
\text { fuel cell ) }\end{array}$ & 40 & $150-300$ & $50-1000$ & $\begin{array}{l}\text { Poison } \\
(<1 \%)\end{array}$ \\
\hline $\begin{array}{c}\text { PEMFC (Polymer } \\
\text { exchange membrane fuel } \\
\text { cell) }\end{array}$ & $40-50$ & $300-1000$ & $\begin{array}{l}0.001- \\
1000\end{array}$ & $\begin{array}{c}\text { Poison } \\
(<50 \mathrm{ppm})\end{array}$ \\
\hline AFC (Alkaline fuel cell) & 50 & $150-400$ & $1-100$ & $\begin{array}{c}\text { Poison } \\
(<50 \mathrm{ppm})\end{array}$ \\
\hline $\begin{array}{l}\text { MCFC (Molten carbonate } \\
\text { fuel cell) }\end{array}$ & $45-55$ & $100-300$ & $\begin{array}{c}100- \\
100,000\end{array}$ & Fuel \\
\hline $\begin{array}{l}\text { SOFC (Solid oxide fuel } \\
\text { cell) }\end{array}$ & $\begin{array}{l}70-80 \text { (with gas } \\
\text { turbine integrated) }\end{array}$ & Up to 1000 & $\begin{array}{c}10- \\
100,000\end{array}$ & Fuel \\
\hline
\end{tabular}

Table 2.1 Comparison summary of the major fuel cells (partially reprinted from Ref 5)

A single SOFC generally has three main components, the anode, the cathode, and the electrolyte in a "sandwich" structure. A sketch of the SOFC is shown in Figure 2.2. 


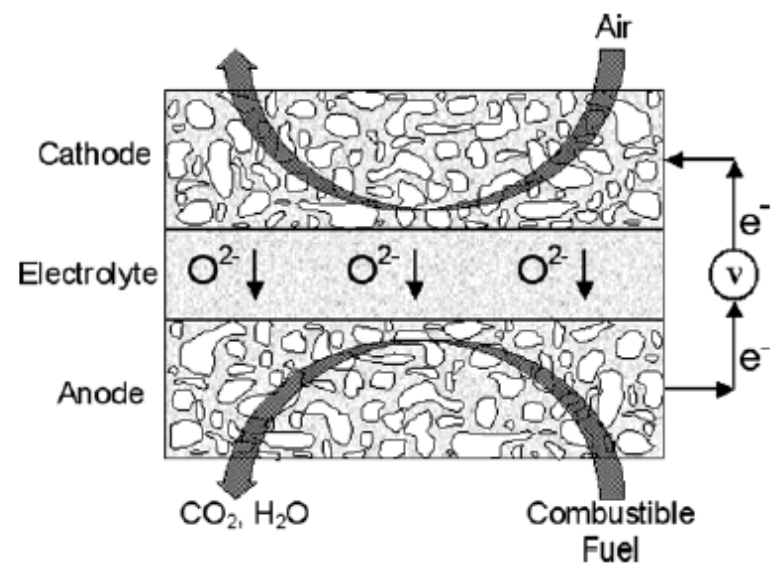

Figure 2.2 Schematic illustration of the SOFC (Ref 6)

During operation, fuel is supplied to the anode and oxygen is fed into the cathode. A dense oxygen ion conducting electrolyte is needed to separate the two gases. Using $\mathrm{H}_{2}$ as the example, the reactions occur at each electrode can be written as

$$
\text { Cathode: } \mathrm{O}_{2}+4 e^{-}=2 \mathrm{O}^{2-}
$$

After the $\mathrm{O}_{2}$ in the air has been reduced to $\mathrm{O}^{2-}$, these ions will pass through the electrolyte to reach the anode. The anode reaction is:

$$
\text { Anode: } 2 \mathrm{H}_{2}+\mathrm{O}^{2-}=2 \mathrm{H}_{2} \mathrm{O}+4 e^{-}
$$

The overall reaction is

$$
2 \mathrm{H}_{2}+\mathrm{O}_{2}=2 \mathrm{H}_{2} \mathrm{O}
$$

The cell open circuit potential can be calculated using the Nernst equations as:

$$
E=E_{o}-\frac{R T}{2 F} \ln \frac{a H_{2} O}{a H_{2} a O_{2}^{1 / 2}}
$$

where $E_{o}=-\frac{\Delta G}{4 F}$. ( $\mathrm{R}$ is the gas constant, $\mathrm{T}$ is the temperature in $\mathrm{K}, \mathrm{F}$ is the Faraday constant, $\Delta G$ is the Gibbs free energy change of the total reaction at given temperature, and $a$ is the chemical activity for the relevant species). Roughly a SOFC can offer around $1 \mathrm{~V}$ potential at open circuit condition using $\mathrm{H}_{2}$ as fuel and air as oxidant.

The materials used for SOFC anode, cathode and electrolyte are all special to meet their demands. Some requirements for SOFC materials include proper stability 
(chemical, phase, morphological and dimensional) in oxidizing and/or reducing environments, chemical compatibility with other components and a proper conductivity.

The most commonly used cathode materials is strontium doped lanthanum manganite (LSM) [4], in which the variable valence of the Mn offers the capability for catalyzing $\mathrm{O}_{2}$ reduction. Recently, mixed ion-electron conductor (MIEC) such as lanthanum-strontium ferrite (LSF) [7], lanthanum-strontium cobaltite (LSC) [8] and lanthanum-strontium cobaltite ferrite (LSCF) [9] have been investigated for intermediate temperature SOFC cathode application and show good catalytic activity and conductivity from $500^{\circ} \mathrm{C}$ to $750^{\circ} \mathrm{C}$.

The electrolyte widely used now is yttria stabilized zirconia (YSZ). YSZ is a pure oxygen ion conductor which restricts the electron current passing from anode to cathode. The Y dopant can stabilize the crystal structure of zirconia to be cubic; substituting the $\mathrm{Zr}$ with $\mathrm{Y}$ also generates oxygen vacancy which will promote the ion conductivity [10]. New class of electrolyte such as doped ceria (Gd or Sm doped) is also used for its higher oxygen ion conductivity [11]. The major disadvantage of ceria based electrolyte is that it has electron conductivity at high temperature and reduced environment, which could cause electron cross over through the electrolyte [12].

The state of art anode system is composed of Ni and YSZ. In the system, Ni is not only the catalyst but also the electron conductor to transport electrons to the current collectors. Considering the cost, the catalysis property and the conductivity, $\mathrm{Ni}$ is so far the best anode catalyst. YSZ is added for two purposes. One is to promote ion conductivity to transport the oxygen ions from the electrolyte to the anode as a conductive path; another role is to adjust the thermal expansion of the anode close to electrolyte for easier sintering [10].

Besides the materials composition, the microstructure of the SOFC electrode and electrolyte is also vital for the performance. The electrodes need to be porous which could promote the gas diffusion; a high surface area is needed for gas/solid interface catalysis reactions. A good SOFC electrode will contain large amount of pores as shown in Figure 2.3 (a). Another important concept in SOFC electrode is the TPB (triple phase boundary), where the gas, the catalyst and the oxygen ion conductor meet together. For anode, it is defined as $\mathrm{Ni}, \mathrm{YSZ}$ and $\mathrm{H}_{2}$ three phases and in cathode it usually points to the 
junction of LSM, YSZ and $\mathrm{O}_{2}$. Theoretically the electrochemical reaction can only occur at the TPB. A schematic of the TPB of the anode side is shown in Figure 2.3 (b).
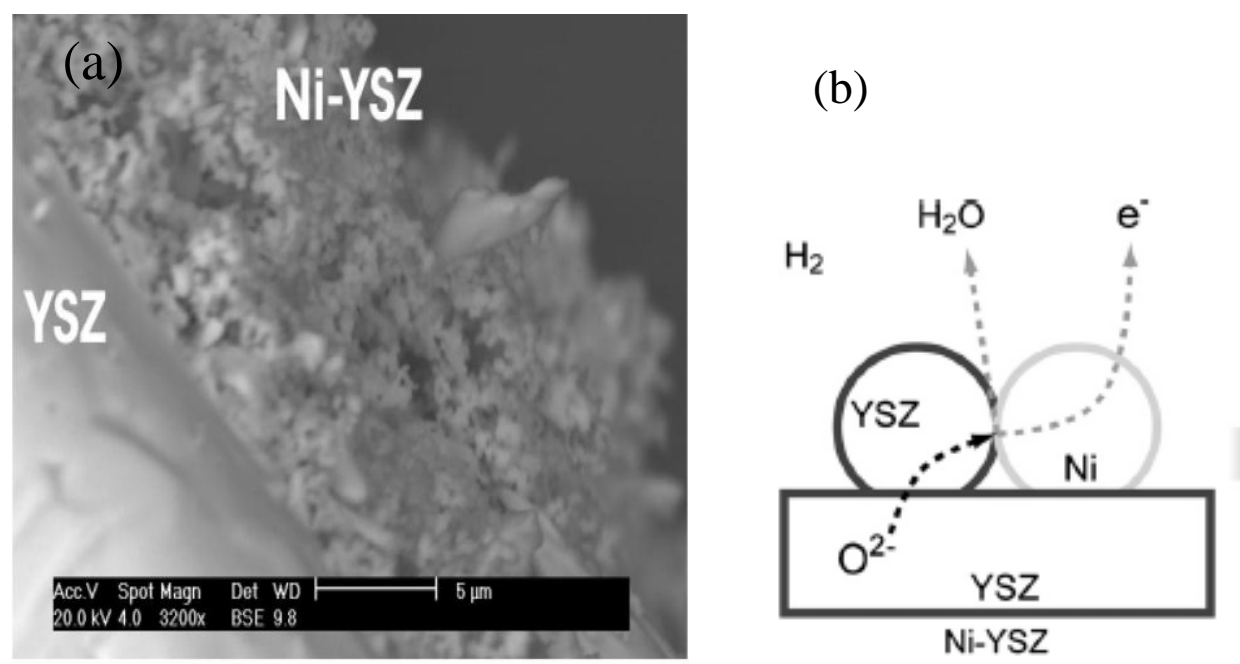

Figure 2.3 (a) the porous anode structure [13] and (b) the schematic map of the triple phase boundary (TPB), anode side [14].

\subsection{Trace Impurities in Coal Derived Syngas:}

Coal syngas is derived from coal gasification process, a technique that converts the solid coal to be gas phase consists of $\mathrm{H}_{2}, \mathrm{H}_{2} \mathrm{O}, \mathrm{CO}, \mathrm{CO}_{2}$, etc. In a gasification reactor, the coal is mixed with air with steam at high pressure (24-70 atm) and high temperature $\left(500-1800^{\circ} \mathrm{C}\right)[15,16]$, the basic reactions of the coal gasification are:

$$
\begin{gathered}
2 \mathrm{C}+\mathrm{O}_{2}=2 \mathrm{CO} \\
\mathrm{C}+\mathrm{H}_{2} \mathrm{O}=\mathrm{CO}+\mathrm{H}_{2} \\
\mathrm{CO}+\mathrm{H}_{2} \mathrm{O} \Leftrightarrow \mathrm{CO}_{2}+\mathrm{H}_{2}
\end{gathered}
$$

The main composition of the CSG is shown in Table 2.2.

\begin{tabular}{|c|c|}
\hline Component & Concentration (vol. \%) \\
\hline $\mathrm{H}_{2}$ & 30.6 \\
\hline $\mathrm{CO}$ & 30.0 \\
\hline $\mathrm{CO}_{2}$ & 11.8 \\
\hline $\mathrm{H}_{2} \mathrm{O}$ & 27.6 \\
\hline
\end{tabular}

Table 2.2 Typical coal syngas composition $[15,16]$ 
Among this process, the impurities existing in the coal will also be vaporized or gasified. The amount and the species of such impurities strongly rely on the coal and the gasification process. Therefore, cleanup techniques like absorption, diffusion through a membrane; chemical conversion and filtering have been employed to remove some of the species like $\mathrm{H}_{2} \mathrm{~S}$, halides and fly ash particles. However, not many effective ways have been developed to remove other trace elements such as As, P, Zn, etc. Trembly et al reported the typical trace impurities in coal syngas, which are listed in Table 2.3 [17].

\begin{tabular}{|c|c|}
\hline Components & Concentration (ppm) \\
\hline $\mathrm{AsH}_{3}$ & 0.6 \\
\hline $\mathrm{HCl}$ & 1.91 \\
\hline $\mathrm{PH}_{3}$ & 0.07 \\
\hline $\mathrm{Sb}$ & 0.011 \\
\hline $\mathrm{Cd}$ & 0.025 \\
\hline $\mathrm{Be}$ & 6 \\
\hline $\mathrm{Cr}$ & 0.025 \\
\hline $\mathrm{Hg}$ & 512 \\
\hline $\mathrm{K}$ & 0.15 \\
\hline $\mathrm{Se}$ & 320 \\
\hline $\mathrm{Na}$ & 0.025 \\
\hline $\mathrm{V}$ & 0.26 \\
\hline $\mathrm{Pb}$ & 9 \\
\hline $\mathrm{Zn}$ & 1 \\
\hline
\end{tabular}

Table 2.3 Trace species and concentration in coal syngas [reprinted from Ref 17]

Although the main chemical formats and the concentrations of these trace elements can be understood, it is still not clear what the real composition will be under SOFC working conditions. As the gas was heated to $800^{\circ} \mathrm{C}$, it will be possible that the impurities react with the bulk composition. Equilibrium gas phase calculation based on the lowest Gibbs free energy may offer such information. It has been reported that the 
same trace impurities have different chemical status at different temperatures [18]. For example, Arsenic exists in $\mathrm{AsH}_{3}$ at the temperature lower than $100^{\circ} \mathrm{C}$, and when the temperature raised to $100^{\circ} \mathrm{C}$ to $400^{\circ} \mathrm{C}$ range, the main specie will be $\mathrm{As}_{2}$, as the temperature further raised to be 400 to $800^{\circ} \mathrm{C}$, where is the range SOFC operates, AsO and $\mathrm{As}_{4}$ dominated. Other trace elements also showed the similar behavior. Krishnan et al. have calculated some selective impurities with different form at different temperatures, a summary of their results is listed in Table 2.4. Their results reveal that it needs to be very careful when examining the reactants for proposing the reaction mechanism between the impurities and the anode.

\begin{tabular}{|c|c|c|c|c|}
\hline Element & $>1000^{\circ} \mathrm{C}$ & $400^{\circ} \mathrm{C}$ to $800^{\circ} \mathrm{C}$ & $100^{\circ} \mathrm{C}$ to $400^{\circ} \mathrm{C}$ & $<100^{\circ} \mathrm{C}$ \\
\hline As & $\mathrm{AsO}, \mathrm{As}_{2}$ & $\mathrm{AsO}, \mathrm{As}_{4}$ & $\mathrm{As}_{2}$ & $\mathrm{AsH}_{3}$ \\
\hline $\mathrm{Be}$ & $\mathrm{Be}(\mathrm{OH})_{2}$ & $\begin{array}{c}\text { Condensed } \\
\text { Species }\end{array}$ & $\begin{array}{c}\text { Condensed } \\
\text { Species }\end{array}$ & $\begin{array}{c}\text { Condensed } \\
\text { Species }\end{array}$ \\
\hline $\mathrm{Hg}$ & $\mathrm{Hg}$ & $\mathrm{Hg}$ & $\mathrm{Hg}, \mathrm{HgCl}_{2}$ & $\mathrm{Hg}, \mathrm{HgCl}_{2}$ \\
\hline B & $\mathrm{HBO}$ & $\mathrm{HBO}$ & HBO & \\
\hline $\mathrm{V}$ & $\mathrm{VO}_{2}$ & $\begin{array}{c}\text { Condensed } \\
\text { Species }\end{array}$ & $\begin{array}{c}\text { Condensed } \\
\text { Species }\end{array}$ & $\begin{array}{c}\text { Condensed } \\
\text { Species }\end{array}$ \\
\hline $\mathrm{Se}$ & & & & $\mathrm{H}_{2} \mathrm{Se}$ \\
\hline $\mathrm{Ni}$ & $\mathrm{NiCl}, \mathrm{NiCl}_{2}$ & $\begin{array}{c}\text { Condensed } \\
\text { Species }\end{array}$ & $\mathrm{Ni}(\mathrm{CO})_{4}$ & $\mathrm{Ni}(\mathrm{CO})_{4}$ \\
\hline Co & $\mathrm{CoCl}, \mathrm{CoCl}_{2}$ & $\begin{array}{c}\text { Condensed } \\
\text { Species }\end{array}$ & $\begin{array}{c}\text { Condensed } \\
\text { Species }\end{array}$ & $\begin{array}{c}\text { Condensed } \\
\text { Species }\end{array}$ \\
\hline $\mathrm{Sb}$ & $\mathrm{Sb}_{2}, \mathrm{SbO}$ & $\mathrm{Sb}_{2}, \mathrm{SbO}$ & $\mathrm{Sb}_{4}$ & $\begin{array}{c}\text { Condensed } \\
\text { Species }\end{array}$ \\
\hline $\mathrm{Cd}$ & $\mathrm{Cd}$ & $\mathrm{Cd}$ & $\mathrm{CdCl}_{2}$ & $\begin{array}{c}\text { Condensed } \\
\text { Species }\end{array}$ \\
\hline $\mathrm{Pb}$ & $\mathrm{Pb}, \mathrm{PbCl}_{2}$ & $\mathrm{PbS}, \mathrm{Pb}, \mathrm{PbCl}_{2}$ & $\begin{array}{c}\text { Condensed } \\
\text { Species }\end{array}$ & $\begin{array}{c}\text { Condensed } \\
\text { Species }\end{array}$ \\
\hline $\mathrm{Zn}$ & $\mathrm{Zn}$ & $\mathrm{Zn}, \mathrm{ZnCl}_{2}$ & $\begin{array}{c}\text { Condensed } \\
\text { Species }\end{array}$ & $\begin{array}{c}\text { Condensed } \\
\text { Species }\end{array}$ \\
\hline
\end{tabular}

Table 2.4 A list of different impurities and their chemical compositions changing in different temperatures ranges(reprinted from Ref 18)

\subsection{Effects of Impurities on SOFC Anode:}


The effects of the trace impurities in coal syngas on SOFC anodes have drawn a lot of attentions due to the motivation of direct utilization CSG as the fuel of SOFC. Thermodynamic equilibrium calculations have indicated that trace impurities species such as $\mathrm{Be}, \mathrm{Cr}, \mathrm{K}, \mathrm{Na}$, and $\mathrm{V}$ in the coal syngas form condensed phases under warm gas cleanup conditions and can be effectively removed by the cleanup processes. Experimental results show that the existence of $\mathrm{Hg}, \mathrm{Si}, \mathrm{Zn}$ and $\mathrm{NH}_{3}$ in the coal syngas does not significantly affect the performance of the Ni-YSZ anode. The presence of Cd and $\mathrm{Se}$ in the syngas has impacts on the SOFC anode performance to some extent. Impurity species such as $\mathrm{Cl}, \mathrm{Sb}$, As, and $\mathrm{P}$ cause severe cell performance degradation due to attack on the Ni-YSZ anode. Sb, As and P have the potential to react with $\mathrm{Ni}$ to form secondary phases in the Ni-YSZ anode, which deteriorate the catalytic activity of the anode. The effects of specific impurities are described as follows.

\section{Sulfur:}

Sulfur is well known to have negative effects on the SOFC anode. The main specie of $\mathrm{S}$ present in most convention fuel gas like natural gas is $\mathrm{H}_{2} \mathrm{~S}$. It has been reported that CSG will contain 100-300 ppm $\mathrm{H}_{2} \mathrm{~S}$ and in natural gas the concentration will be higher than $1 \%$. The detailed degradation mechanism has been proposed as follows [19]:

1. Physical absorption of $\mathrm{H}_{2} \mathrm{~S}$ at the surface of the Ni-YSZ anode reduces the effective region for electrochemical reactions. This usually causes a rapid degradation of the SOFC performance.

2. The absorbed $\mathrm{H}_{2} \mathrm{~S}$ further reacts with $\mathrm{Ni}$ to form $\mathrm{Ni}$ sulfide. This process reduces the electrochemical catalysis and reaction regions and causes a steady slow loss of the performance.

The chemical reactions involved in this process will be:

$$
\begin{gathered}
H_{2} S(g) \Leftrightarrow H S_{a d s}+H(g / a d s) \Leftrightarrow S_{a d s}+H_{2}(g / a d s) \\
N i+H_{2} S \Leftrightarrow N i S+H_{2} \\
3 N i+x H_{2} S \Leftrightarrow N i_{3} S_{x}+x H_{2}
\end{gathered}
$$

An important phenomenon of the Sulfur poisoning effects is the "self-recovery" [19, 20]. Some researchers found if the $\mathrm{H}_{2} \mathrm{~S}$ exposure time is not long; the cell performance 
will be recovered when the fuel is switched back to clean fuel gas. A typical recovery plot is shown in Figure 2.4.

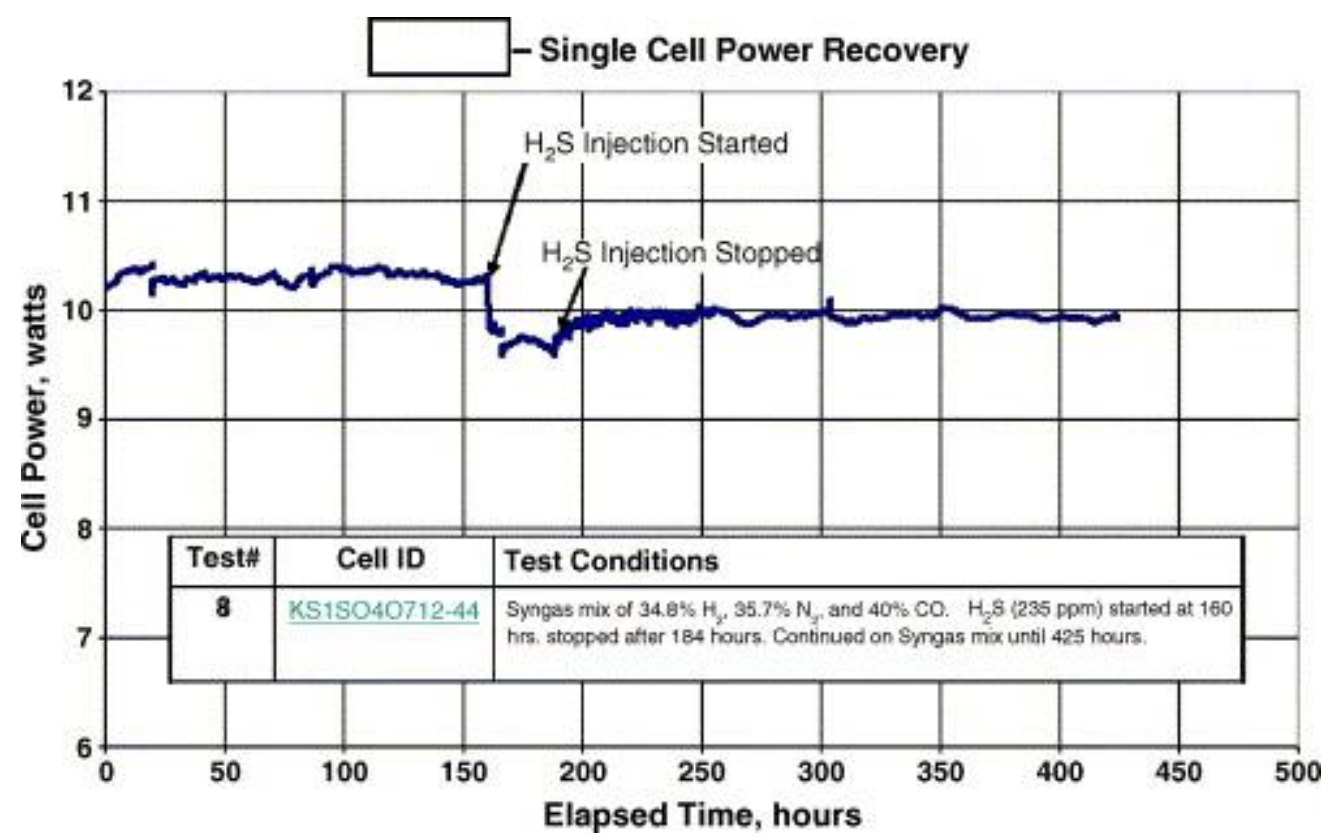

Figure 2.4 Sulfur poison recovery (reprinted from Ref 20)

The main reason for such recovery behavior is the removal of the surface adsorptive $\mathrm{H}_{2} \mathrm{~S}$, so the surface activation region can be revealed again. But still there are debates on this issue that whether such process is reversible. Some kinds of Sulfur tolerant anode materials or electrode design strategies have been studied. Using $\mathrm{Cu}$-Ceria instead of $\mathrm{Ni}$ YSZ or some perovskite ceramics as anode, some level of $\mathrm{S}$ tolerant properties have been found, though the performances are lower than traditional Ni-YSZ cermet.

\section{Chlorine (Cl):}

Chlorine is present in coal syngas in two major forms: $\mathrm{HCl}$ and $\mathrm{CH}_{3} \mathrm{Cl}$, both of the chemicals were used for evaluation the poisoning effect to Ni-YSZ anodes [21-24]. Recently, $\mathrm{Cl}_{2}$ was also used with $\mathrm{H}_{2}$ on Ni-ScSZ (Sc stabilized Zirconia) anodes for investigating the degradation [25]. It has been found that the degradation ratio depends on the operation temperature and the specie concentrations or even the current loads, and the observed results are not always the same. 
For $\mathrm{HCl}, 40 \mathrm{ppm}$ at $750^{\circ} \mathrm{C}$ and $800^{\circ} \mathrm{C}$ showed no significant degradation over 100 hours under $0.2 \mathrm{~A} / \mathrm{cm}^{2}$ load, however, contrast results showed $20 \mathrm{ppm} \mathrm{HCl}$ at $800^{\circ} \mathrm{C}$ with approximated $0.3 \mathrm{~A} / \mathrm{cm}^{2}$ current load caused a rapid SOFC performance drop at initial state, and the same phenomenon was found for $900^{\circ} \mathrm{C}, 20 \mathrm{ppm} \mathrm{HCl}$ case. After 20 hours, the cells underwent a steady state [22]. When the $\mathrm{HCl}$ concentration increasing to 160 ppm, the cell operated at $900^{\circ} \mathrm{C}$ showed a steady degradation with higher rate, however, the $800^{\circ} \mathrm{C}$ cell showed similar behavior as $750^{\circ} \mathrm{C}$ cells with slower rate. Impedance spectra revealed the degradation is mainly caused by charge transfer resistance increasing at lower temperature $\left(800^{\circ} \mathrm{C}\right)$ when at higher temperature both the charge transfer and the ohmic contact resistance increased. Other result was reported in Ref 24 when 100 ppm $\mathrm{HCl}$ was fed at $800^{\circ} \mathrm{C}$, no contact resistance increasing was found. It is notable $\mathrm{HCl}$ is very corrosive to stainless steel [24].

The degradation behavior of $\mathrm{CH}_{3} \mathrm{Cl}$ is strongly related with temperature. The cell could tolerate $40 \mathrm{ppm} \mathrm{CH}_{3} \mathrm{Cl}$ at $800^{\circ} \mathrm{C}$ but at $850^{\circ} \mathrm{C}$, the performance decreased. This may be caused by the temperature controlled reaction kinetics either in gas phase or between gas phase and the anode.

Another $\mathrm{Cl}$ impurity used is $\mathrm{Cl}_{2} .5 \mathrm{ppm} \mathrm{Cl}_{2}$ at $800^{\circ} \mathrm{C}$ turned to be the threshold, and the degradation rate is proportional to $\mathrm{Cl}_{2}$ concentration. The loss was mainly due to the anodic over potential rather than contact resistance. It is notable that such degradation is partially reversible, which means absorption and desorption process should be involved as sulfur poisoning [25].

The mechanism underlying the degradation was explained by the formation of nickel chlorides. The chemical reaction can be written as [22, 25]:

$$
\begin{gathered}
\mathrm{Ni}(s)+2 \mathrm{HCl}(g) \Leftrightarrow \mathrm{NiCl}_{2}(g, s)+\mathrm{H}_{2}(g) \\
\mathrm{Ni}(s)+\mathrm{Cl}_{2}(g) \Leftrightarrow \mathrm{NiCl}_{2}(g, s)
\end{gathered}
$$

The formation of the secondary phase will block the active region on the anode and make the catalyst property loss. The argument is if the $\mathrm{NiCl}_{2}$ is in solid or gas phase format. Haga et al [25] proposed the gas form $\mathrm{NiCl}_{2}$, as the ratio of $\mathrm{Ni} / \mathrm{Zr}$ decreased after the impurity test due to the flow of $\mathrm{NiCl}_{2}$ vapor off the cell. A post material characterization showed no $\mathrm{NiCl}_{2}$ was found in $800^{\circ} \mathrm{C}, 100 \mathrm{ppm} \mathrm{HCl}$ fed anode, which supports this claim. Another proof for this hypothesis is Ni small particles formed on the zirconia electrolyte 
surface when the $\mathrm{Cl}$ concentration is low, which is due to the reversible reaction of the nickel chlorides formation which decomposed $\mathrm{NiCl}_{2}$ to form $\mathrm{Ni}$ again. Trembly's calculation results considered $\mathrm{NiCl}_{2}$ was in solid form, and no observation of the small $\mathrm{Ni}$ particles deposition was found [22]. This may due to the high $\mathrm{HCl}$ concentrations in his experiments so the nickel chlorides formation reaction was favorable. In summary, the $\mathrm{Cl}$ will consume $\mathrm{Ni}$ by forming secondary phase, which causes the anode to lose its catalytic activity and electron conductivity.

\section{Arsenic (As):}

Arsenic species could have various forms in coal syngas including $\mathrm{AsH}_{3}, \mathrm{As}_{2}$ and $\mathrm{As}_{4}$ depending on the gasification process [23]. The degradation caused by introduction $\mathrm{AsH}_{3}$ to the fuel is mainly because of the NiAs secondary phase formation which is less electronic conductive [26-28]. Post exposure characterization reveals that As mainly located on Ni site which is consisted with thermal dynamics calculation as the NiAs alloy is predicted [22].

\section{Mercury (Hg):}

The mercury effects have relationship with the concentration. In lower concentration case (180 ppb), 750 and $800^{\circ} \mathrm{C}$ cells can stand, or even working better, but the degradation appeared at $850^{\circ} \mathrm{C}$. For the higher concentration $(7 \mathrm{ppm})$, the degradation was also more serious at higher temperature $\left(800^{\circ} \mathrm{C}\right)$ compared at $750^{\circ} \mathrm{C}$. A possible reason is $\mathrm{Ni}$ and $\mathrm{Hg}$ forming low melting point eutectic alloy [29].

\section{Phosphorus (P):}

$\mathrm{PH}_{3}$ and $\mathrm{P}_{\mathrm{x}} \mathrm{O}_{\mathrm{y}}$ have been chosen for $\mathrm{P}$ related effects study [30-41]. It is been believed that $\mathrm{PH}_{3}$ might be the main specie in coal syngas, though some gas phase equilibrium calculations showed $\mathrm{PH}_{3}$ would be oxidized in $\mathrm{P}_{\mathrm{x}} \mathrm{O}_{\mathrm{y}}$ form because of the high steam concentration [32]. Also, the mechanism is on debate although the degradation behavior is well confirmed. The thermodynamics calculation results of the reaction between $\mathrm{PH}_{3}$ and $\mathrm{Ni}$ showed $\mathrm{Ni}_{5} \mathrm{P}_{2}$ could be the stable product. The formation of this nickel phosphide was blamed for the cell performance loss. Treambly et al thought 
when the $\mathrm{PH}_{3}$ would be oxidized to be $\mathrm{P}_{2} \mathrm{O}_{3}$ or $\mathrm{P}_{2} \mathrm{O}_{5}$, the amount of $\mathrm{Ni}_{5} \mathrm{P}_{2}$ should be reduced so the degradation could be minimized as oxygen was present. However, there is other evidence showed even $\mathrm{P}_{2} \mathrm{O}_{5}$ or $\mathrm{HPO}_{2}$ could degrade the cells [27]. Krishnan et al found that $10 \mathrm{ppm} \mathrm{P}_{2} \mathrm{O}_{5}$ or $\mathrm{HPO}_{2}$ could poison the cells at 750 and $800^{\circ} \mathrm{C}$. So one should take caution to consider if the degradation was caused by one single chemical even the injected impurity was $\mathrm{PH}_{3}$ alone.

The reactions of $\mathrm{PH}_{3}$ with the anode also became unclear due to the variability of the reactants. Marina et al $[30,39]$ declared in their experiments the product was $\mathrm{Ni}_{3} \mathrm{P}$

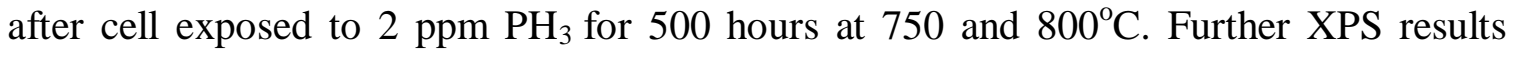
showed the phosphorous was in positive charged status which was opposite to their declaration. Although they claimed this was due to an abortion layer but the ToF-SIMS line scan detected $\mathrm{PO}_{3}{ }^{-}$and $\mathrm{PO}_{2}{ }^{-}$ions all the way along the cross section of the anode. From these results, the final product might be phosphate instead of phosphide. $\mathrm{P}_{2} \mathrm{O}_{5}$ was also found to react with YSZ as Krishnan et al detected P appeared in YSZ site after the cells exposure in $\mathrm{P}_{2} \mathrm{O}_{5}$. Based on these previous works, it may be proposed that when the $\mathrm{P}$ impurities (whatever the form) were introduced, both the Ni and YSZ in the anode would be affected; this is in contrast with As as it only reacted with $\mathrm{Ni}$.

One interesting phenomenon discovered when studying the $\mathrm{P}$ effects to SOFC anode is that after exposing in $\mathrm{PH}_{3}$, a Ni-P compound layer will cover the electrode surface and bury the YSZ layer [33-40]. The detail mechanism for such Ni migration behavior is unknown. It may be caused by the migration of Ni metal to the anode surface or the chemical grads of $\mathrm{Ni}$ as the surface $\mathrm{Ni}$ was consumed by the impurities.

The diffusion behavior of $\mathrm{P}$ into Ni-YSZ anode has also been studied. It is found for thinner anode such used in electrolyte support cells, the shorter time for $\mathrm{P}$ to penetrate

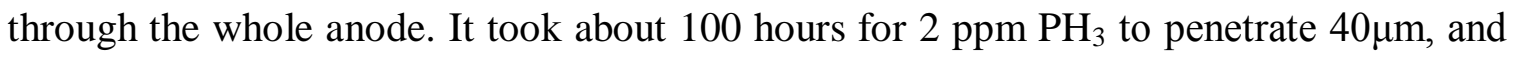
higher concentration took less time. This reveals for better P tolerant, thick anode should be used. Again, the out diffusion of $\mathrm{Ni}$ to anode surface in $\mathrm{PH}_{3}$ impurity was confirmed in this work [30, 39].

It is also found the degradation behaviors of $\mathrm{Ni}$-YSZ anode in $\mathrm{PH}_{3}$ contained syngas strongly depend on several factors such as temperatures, $\mathrm{PH}_{3}$ concentration, fuel gas used as well as the loading current. As Demircan pointed out, the degradation may 
accelerate at higher cell overpotential [38]. Xu et al found the cell power loss is larger at higher temperature $\left(850^{\circ} \mathrm{C}\right)$ compared with at $750^{\circ} \mathrm{C}$ which could be result of enhanced diffusion of $\mathrm{PH}_{3}$ [36]. Guo et al [41] claimed the degradation is a coupling effect of steam and $\mathrm{PH}_{3}$ when $\mathrm{Xu}$ et al found the degradation is independent of $\mathrm{H}_{2} \mathrm{O}$ concentration in the fuel gas [36]. The result secondary phase is also contrary. Marina [39] and $\mathrm{Xu}[35,36]$ et al found $\mathrm{Ni}$ phosphide as the primary product of the interaction of $\mathrm{Ni}$ with $\mathrm{PH}_{3}$ when Zhi et al thought Ni phosphate was formed. Guo's result indicates a mixture of Ni phosphide and phosphate [41] as the poison product. It should be noted that the distinction may come from different test conditions such as cell configuration and testing rig, which is varied from site to site. For example, Zhi et al. used electrolyte supported half cell $[31,33]$ when others using anode supported full cell.[36, 41] The current collecting mesh also had different geometry in different research. [36, 41]

So far there are limited reports of developing new anode materials which can tolerate $\mathrm{PH}_{3}$ poison. Gong et al evaluated the performance of $\mathrm{LaSr}_{2} \mathrm{Fe}_{2} \mathrm{CrO}_{9-\delta}$ which is sulfur tolerated materials in $\mathrm{PH}_{3}$ contained syngas; however, secondary phase formation and electrochemical performance degradation were observed [42].

\section{Antimony (Sb):}

Trembly et al calculated the reaction of $\mathrm{Ni}$ with $\mathrm{Sb}$, which gives $\mathrm{NiSb}$ alloy; it is found the Ni convention ratio is not high [18]. The work consisted with the Krishnan's experimental results when he found no major degradation occurred at 800 and $850^{\circ} \mathrm{C}$ for SOFC performance with 8ppm SbO [29]. However, a increasing of the performance was found at $750^{\circ} \mathrm{C}$. The improvement is small so it is not clear of the mechanism.

\section{Cadmium (Cd):}

Cadmium $(\mathrm{Cd})$ is a heavy metal element. It is been reported as one of the most volatile metal impurities in coal syngas. The typical size of these fractions is less than $0.45 \mu \mathrm{m}$ [43]. Cd vapor has been confirmed to affect the SOFC performance. Very few data was disclosed and it showed that $5 \mathrm{ppm} \mathrm{Cd}$ can degrade cell for approximate $25 \%$ at $850^{\circ} \mathrm{C}$ in 120 hours, when the temperature dropped to $800^{\circ} \mathrm{C}$, no significant degradation can be observed [29]. It is not clear of the mechanism. From the phase diagram, Ni-Cd 
should present in $\mathrm{Ni}+$ liquid form above $680^{\circ} \mathrm{C}$ when the $\mathrm{Cd}$ content is lower than $55 \%$ [44]. The degradation behavior at different temperature may be related to reaction kinetics.

\section{Zinc (Zn):}

Like $\mathrm{Cd}, \mathrm{Zn}$ is also in condensed particle form in coal syngas [43]. Some data shows Zn vapor will be carried over the SOFC anode and not deposit. The SOFC performance which gained with $10 \mathrm{ppm} \mathrm{Zn}$ vapor at 750 and $800^{\circ} \mathrm{C}$ showed minor degradation, which may confirm the carry out effect $[23,45]$.

\section{Ammonia ( $\left.\mathbf{N H}_{3}\right)$ :}

$\mathrm{NH}_{3}$ presents in coal syngas in large volume. It has been reported the limit tolerance for $\mathrm{SOFC}$ at $1000^{\circ} \mathrm{C}$ is $5000 \mathrm{ppm}$ [45]. Such operation condition is not applicable for the modern SOFC because of the lower temperature now using. It is found that over $86 \%$ $\mathrm{NH}_{3}$ would be decomposed at about $870^{\circ} \mathrm{C}$ in the present of $30 \% \mathrm{H}_{2}$ and $32 \% \mathrm{CO}$ [46]. So it is possible the high temperature operating SOFC can tolerate $\mathrm{NH}_{3}$ at high concentration.

\section{Sodium (Na):}

$\mathrm{Na}$ may be introduced to Ni-YSZ anode in fabrication or testing process. Morgensen et al artificially introduced $\mathrm{Na}$ impurity to $\mathrm{Ni}-\mathrm{YSZ}$ anode by using low grade $\mathrm{NiO}$ as the raw materials for preparing cells. It is been found a glossy layer of $\mathrm{Na}_{2} \mathrm{O}$ and $\mathrm{SiO}_{2}$ is formed on the interface of the electrode/electrolyte, and the resistance of the cells increased about 1.8 times $\left(0.35 \Omega \mathrm{cm}^{2}\right.$ to $\left.0.65 \Omega \mathrm{cm}^{2}\right)$ [47]. Such phenomenon is worth to consider when using glass seals for SOFC applications.

\section{Silicon (Si):}

Silicon contained in the fuel gas is in the form of $\mathrm{Si}(\mathrm{OH})_{4}$, and it will decompose into $\mathrm{SiO}_{2}$ and $\mathrm{H}_{2} \mathrm{O}$, with $\mathrm{SiO}_{2}$ deposited on the anode surface and form a silica rich 
region [47]. Beside in the gas phase, $\mathrm{Si}$ will also be present in the gas sealing component. Again, the combined effect of $\mathrm{Si}$ and $\mathrm{Na}$ has been researched [47]. The accumulation of the impurity on the anode/electrolyte interface would block the TPB region.

\section{Selenium (Se):}

$\mathrm{H}_{2} \mathrm{Se}$ was used for the evaluation of effect of Se effects to SOFC. At $800^{\circ} \mathrm{C}, 0.5$ ppm $\mathrm{H}_{2} \mathrm{Se}$ showed small but steady degradation, almost neglectable, but 5 ppm $\mathrm{H}_{2} \mathrm{Se}$ showed rapid performance loss. Like $\mathrm{S}$ or $\mathrm{Cl}_{2}$, a recovery was found after $\mathrm{H}_{2}$ was introduced. Again, an absorption-desorption process can be proposed to explain the mechanism [48].

Nihan et al [49] summarized most of the present data on the impact of the impurities to SOFC anode; a table lists the as tested impurities and their degradation behavior including the possible tolerant limits in shown below:

\begin{tabular}{|c|c|c|c|c|c|c|c|c|}
\hline Impurity & $\begin{array}{l}\text { Chemical } \\
\text { forms }\end{array}$ & $\begin{array}{l}\text { Tested } \\
\text { temperatures }\end{array}$ & Concentrations & $\begin{array}{l}\text { Degradation } \\
\text { rate }\end{array}$ & $\begin{array}{l}\text { Degradation } \\
\text { behavior }\end{array}$ & Recovery & $\begin{array}{l}\text { Data } \\
\text { sources }\end{array}$ & $\begin{array}{l}\text { Possible } \\
\text { products }\end{array}$ \\
\hline \multirow{5}{*}{ As } & \multirow{3}{*}{$\mathrm{AsH}_{3}$} & & $0.1 \mathrm{ppm}$ & neglectable & & & & \multirow{5}{*}{ NiAs } \\
\hline & & $750^{\circ} \mathrm{C}$ & $1 \mathrm{ppm}$ & $<5 \% 800 \mathrm{hr}$ & $\begin{array}{l}\text { steady drop, } \\
\text { sudden } \\
\text { decreasing } \\
\text { after } 600 \mathrm{hr}\end{array}$ & & Ref 17 & \\
\hline & & $800^{\circ} \mathrm{C}$ & $1 \mathrm{ppm}$ & $<6 \% 600 \mathrm{hr}$ & $\begin{array}{l}\text { steady drop, } \\
\text { plateau after } \\
400 \mathrm{hr}\end{array}$ & & Ref 28 & \\
\hline & \multirow{2}{*}{$\mathrm{As}_{2}$} & $750^{\circ} \mathrm{C}$ & $10 \mathrm{ppm}$ & $<15 \% 70 \mathrm{hr}$ & $\begin{array}{l}\text { initial drop } \\
\text { then stable }\end{array}$ & & \multirow{2}{*}{ Ref 29} & \\
\hline & & $800^{\circ} \mathrm{C}$ & $10 \mathrm{ppm}$ & $\begin{array}{l}\text { Cell dead,50 } \\
\text { hr* }\end{array}$ & & & & \\
\hline \multirow{5}{*}{ Cl } & \multirow{2}{*}{$\mathrm{CH}_{3} \mathrm{Cl}$} & $800^{\circ} \mathrm{C}$ & $10 \mathrm{ppm}$ & neglectable & & & \multirow{5}{*}{$\begin{array}{l}\text { Ref 23- } \\
26\end{array}$} & \multirow{5}{*}{$\mathrm{NiCl}_{2}$} \\
\hline & & $850^{\circ} \mathrm{C}$ & $10 \mathrm{ppm}$ & $\sim 6 \% 150 \mathrm{hr}$ & steady drop & & & \\
\hline & \multirow{3}{*}{$\mathrm{HCl}$} & $750^{\circ} \mathrm{C}$ & $40 \mathrm{ppm}$ & neglectable & & & & \\
\hline & & \multirow{2}{*}{$800^{\circ} \mathrm{C}$} & $20 \mathrm{ppm}$ & $<20 \% 100 \mathrm{hr}$ & $\begin{array}{l}\text { initial drop } \\
\text { then stable }\end{array}$ & & & \\
\hline & & & $40 \mathrm{ppm}$ & $\begin{array}{l}\text { neglectable } \\
* *\end{array}$ & & & & \\
\hline
\end{tabular}




\begin{tabular}{|c|c|c|c|c|c|c|c|c|}
\hline & & & 160 ppm & $\sim 20 \% 100 \mathrm{hr}$ & $\begin{array}{l}\text { initial rapid } \\
\text { drop, then } \\
\text { slow drop, } \\
\text { then stable }\end{array}$ & & & \\
\hline & & & $100 \mathrm{ppm}$ & $3 \% 400 \mathrm{hr}$ & $\begin{array}{l}\text { Slow and } \\
\text { steady drop }\end{array}$ & & & \\
\hline & & $000^{\circ} \mathrm{C}$ & $20 \mathrm{ppm}$ & $\sim 13 \% 100 \mathrm{hr}$ & as above & & & \\
\hline & & C & $160 \mathrm{ppm}$ & $\sim 50 \% 100 \mathrm{hr}$ & steady drop & & & \\
\hline & $\mathrm{Cl}_{2}$ & $800^{\circ} \mathrm{C}$ & $5 \mathrm{ppm}$ & neglectable & & Yes & Ref 25 & \\
\hline \multirow{7}{*}{$\mathbf{P}$} & \multirow{5}{*}{$\mathrm{PH}_{3}$} & $750^{\circ} \mathrm{C}$ & $2 \mathrm{ppm}$ & neglectable & & \multirow{7}{*}{ No } & \multirow{7}{*}{$\begin{array}{l}\text { Ref 30- } \\
41\end{array}$} & \multirow{7}{*}{$\begin{array}{l}\mathrm{Ni}_{3} \mathrm{P}, \mathrm{Ni}_{5} \mathrm{P}_{2} \\
\mathrm{Ni}_{3}\left(\mathrm{PO}_{4}\right)_{2}\end{array}$} \\
\hline & & 1000 & $5 \mathrm{ppm}$ & neglectable & & & & \\
\hline & & $800^{\circ} \mathrm{C}$ & $2 \mathrm{ppm}$ & $40 \% 500 \mathrm{hr}$ & $\begin{array}{l}\text { stable then } \\
\text { drop }\end{array}$ & & & \\
\hline & & & $10 \mathrm{ppm}$ & $20 \% 200 \mathrm{hr}$ & steady drop & & & \\
\hline & & $900^{\circ} \mathrm{C}$ & $20 \mathrm{ppm}$ & $\begin{array}{l}\text { Cell dead,12 } \\
\text { hr } * * *\end{array}$ & rapid drop & & & \\
\hline & \multirow[t]{2}{*}{$\mathrm{P}_{2} \mathrm{O}_{5}$} & $750^{\circ} \mathrm{C}$ & $10 \mathrm{ppm}$ & $\sim 6 \% 120 \mathrm{hr}$ & $\begin{array}{l}\text { initial drop } \\
\text { then stable }\end{array}$ & & & \\
\hline & & $800^{\circ} \mathrm{C}$ & $10 \mathrm{ppm}$ & $\sim 9 \% 80 \mathrm{hr}$ & steady drop & & & \\
\hline \multirow{5}{*}{ Hg } & \multirow{5}{*}{$\begin{array}{l}\mathrm{Hg} \\
\text { vaporr }\end{array}$} & \multirow{2}{*}{$750^{\circ} \mathrm{C}$} & 180ppb & neglectable & & & \multirow{5}{*}{ Ref 23} & \multirow{5}{*}{$\begin{array}{l}\mathrm{Ni}-\mathrm{Hg} \\
\text { alloy }\end{array}$} \\
\hline & & & $7 \mathrm{ppm}$ & $\sim 1 \% 100 \mathrm{hr}$ & steady drop & & & \\
\hline & & \multirow{2}{*}{$800^{\circ} \mathrm{C}$} & $180 \mathrm{ppb}$ & neglectable & & & & \\
\hline & & & $7 \mathrm{ppm}$ & $<2 \% 100 \mathrm{hr}$ & steady drop & & & \\
\hline & & $850^{\circ} \mathrm{C}$ & $180 \mathrm{ppb}$ & neglectable & & & & \\
\hline \multirow{2}{*}{ Cd } & \multirow{2}{*}{ Cd vapor } & $800^{\circ} \mathrm{C}$ & $5 \mathrm{ppm}$ & neglectable & & & \multirow{2}{*}{ Ref 23} & $\mathrm{Ni}-\mathrm{Cd}$ \\
\hline & & $850^{\circ} \mathrm{C}$ & $5 \mathrm{ppm}$ & $\sim 25 \% 120 \mathrm{hr}$ & steady drop & & & alloy \\
\hline \multirow[b]{2}{*}{ Se } & \multirow[b]{2}{*}{$\mathrm{H}_{2} \mathrm{Se}$} & \multirow[b]{2}{*}{$800^{\circ} \mathrm{C}$} & $0.5 \mathrm{ppm}$ & $\sim 5 \% 200 \mathrm{hr}$ & steady drop & & \multirow[b]{2}{*}{ Ref 48} & \\
\hline & & & $5 \mathrm{ppm}$ & $\sim 25 \% 75 \mathrm{hr}$ & $\begin{array}{ll}\text { initial rapid } \\
\text { drop then } \\
\text { stable }\end{array}$ & & & \\
\hline \multirow{3}{*}{ Sb } & \multirow{3}{*}{$\mathrm{SbO}$} & $750^{\circ} \mathrm{C}$ & $8 \mathrm{ppm}$ & neglectable & & & \multirow{3}{*}{ Ref 29} & \multirow{3}{*}{$\mathrm{NiSb}$ alloy } \\
\hline & & $800^{\circ} \mathrm{C}$ & $8 \mathrm{ppm}$ & $\sim 2 \% 160 \mathrm{hr}$ & steady drop & & & \\
\hline & & $850^{\circ} \mathrm{C}$ & $8 \mathrm{ppm}$ & $\sim 2 \% 120 \mathrm{hr}$ & steady drop & & & \\
\hline \multirow{2}{*}{ Zn } & \multirow{2}{*}{$\mathrm{Zn}$ vapor } & $750^{\circ} \mathrm{C}$ & $10 \mathrm{ppm}$ & neglectable & & & Ref & \multirow{2}{*}{$\mathrm{Ni}-\mathrm{Zn}$} \\
\hline & & $800^{\circ} \mathrm{C}$ & $10 \mathrm{ppm}$ & $\sim 3 \% 129 \mathrm{hr}$ & steady drop & & 29,45 & \\
\hline $\mathbf{N H}_{3}$ & $\mathrm{NH}_{3}$ & $1000^{\circ} \mathrm{C}$ & $5000 \mathrm{ppm}$ & neglectable & & & Ref 45 & \\
\hline $\mathbf{S i}+\mathbf{N a}$ & $\mathrm{Si}$ and $\mathrm{Na}$ & $850^{\circ} \mathrm{C}$ & Si 0.02 & $200 \% 600 \mathrm{hr}$ & Initial drop & & Ref 47 & $\mathrm{SiO}-\mathrm{Na}_{2} \mathrm{O}$ \\
\hline
\end{tabular}




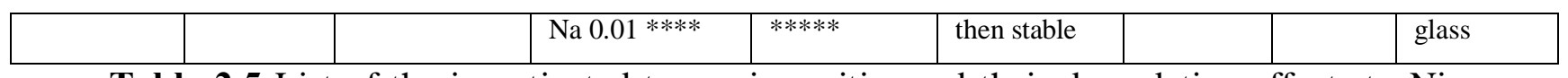

Table 2.5 List of the investigated trance impurities and their degradation effects to $\mathrm{Ni}$ YSZ

* Contact failure

** Performance enhanced

*** Half cell samples

**** Introduced in manufacture, estimated level

***** Derived from ASR data

Based on the summary given above, it could be seen that the cell anode degradation due to the impurities contained coal syngas is strongly related to the following factors:

1. Materials. Ni-YSZ anode could be subject to degradation even when small concentration of impurity was present. The Ni metal is very reactive to the impurity elements. Such effects include: adsorption of the impurities on the anode surface and consequent blockage of gas diffusion channels; secondary phase formation, which will cause loss of catalytic property as well as the electron transfer capability. More detail work such as on $\mathrm{PH}_{3}$ reveals the phase transfer could cause anode surface microstructure reconstruction and further degrade the anode porosity, which may lead to more severe degradation.

2. Operation current/overpotential. For some of the studied impurity elements, the degradation is related to the current loaded to the cell. It can be understood that the current is proportional to the numbers of the electrochemical reactions occurs. Higher currents will lead to more electrochemical interaction between the $\mathrm{Ni}$ and impurity, as well as more fuel gas being consumed, more impurities will be brought in to the anode; therefore the degradation could be accelerated.

3. Operation temperature. A strong relationship between the degradation rate and cell operation temperatures for several impurities has been addressed. The origin for this observation is still unclear. It may relate to the $\mathrm{Ni} / \mathrm{impurity}$ reaction rate increases with temperature, or different phase transfer mechanisms at different temperatures, or an increasing temperature should promote the mass diffusion. 
In order to eliminate, at least minimize the impact of the impurity on the anode, two solutions are taken into account:

1. Developing new anode materials which can tolerate the impurities. Such materials also need to have high fuel catalytic properties, high redox stability, and good electron and oxygen ion conductivities as well as be compatible with other cell components in order to get acceptable performance. So far most of such research is focused on the sulfur tolerant anode, which is mainly based on the perovskite materials. Some initial trials on $\mathrm{PH}_{3}$ tolerate anode have been carried out but no positive results are shown yet [42].

2. Lowering of the operation temperature of the SOFC. As it is summarized above, if the cell is operated at $750^{\circ} \mathrm{C}$, or even lower at $700^{\circ} \mathrm{C}$, some specific impurities impact could be neglectable while some others can be significantly suppressed. Such impurities include $\mathrm{PH}_{3}, \mathrm{CH}_{3} \mathrm{Cl}, \mathrm{HCl}, \mathrm{Hg}$ etc al. It should be note that $\mathrm{P}$ and $\mathrm{Cl}$ are two of the most researched impurities and their poisoning effect to the anode has been confirmed to be very severe. Therefore lowering SOFC operation temperature could offer an alternative solution to prolong the service time of SOFC in impurities contained coal syngas.

\subsection{Strategy of Developing Intermediate Temperature SOFC:}

It is a common agreement that as the SOFC operation temperature is brought down, the cathode requires particular attention due to the high activation energy of the oxygen reduction reaction, whose polarization resistance increases rapidly with decreasing temperature [50]. Figure 2.5 is an example of the $\mathrm{I}-\mathrm{V}$ curve of a SOFC running at $800^{\circ} \mathrm{C}$, it can be seen the cathode polarization loss contributes the majority of the total cell loss. . 


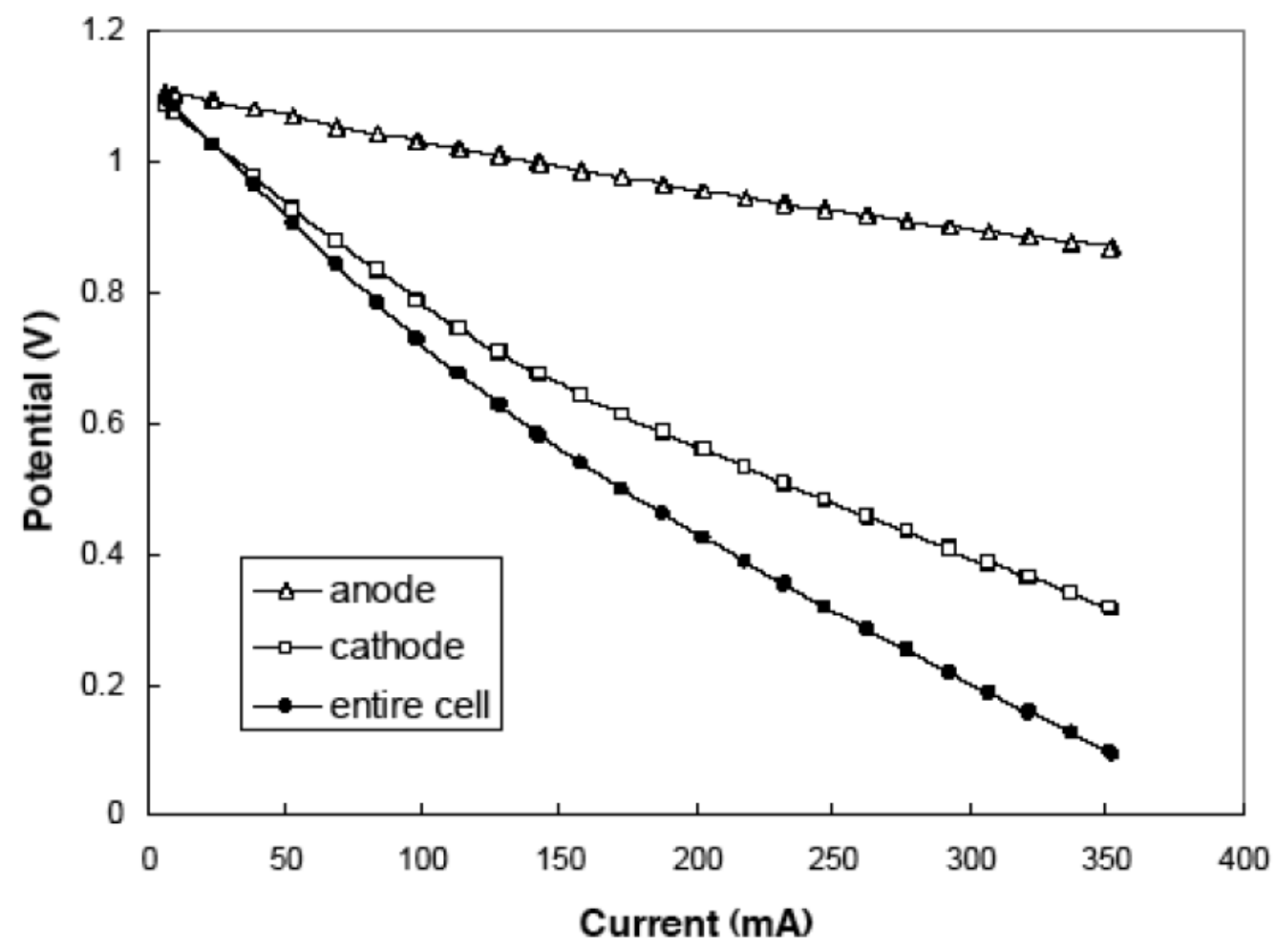

Figure 2.5 Typical I-V curve of SOFC operated at $800^{\circ} \mathrm{C}$, the polarization loss is separated for anode and cathode, respectively [51]

Therefore optimizing SOFC cathode is most important in order to achieve acceptable performance at temperature below $800^{\circ} \mathrm{C}$. The cathode performance depends on the electronic/ionic conductivity of the electrode, gas transport through electrode porosity, and the electrocatalytic activity at the three-phase boundary (TPB) areas among the gas, the electrolyte and the cathodes [50]. Improvement of cathode performance can be achieved by development of new materials and/or optimization of electrode architecture/microstructure. Recently two pathways are carried out correlatively based on above argument.

\section{Materials development}

The conventional SOFC cathode material is LSM/YSZ mixture which was initiated by Minh in his paper "Ceramic Fuel Cells" published in 1993. After that such composite cathode replaced precious metal cathode and became prevalent [52]. Good performance can be reached with $1.5 \mathrm{~W} / \mathrm{cm}^{2}$ power output using $\mathrm{LSM} / \mathrm{YSZ}$ cathode at 
$800^{\circ} \mathrm{C}$. Detailed studies such as sintering temperature, composition ratio, reaction mechanism as well as materials defects chemistry have been carried out. Recently, new class of MIEC (Mixed Ionic and Electronic Conductor) are developed for the intermediate temperature SOFC cathode application, which would greatly reduce the cathode overpotential by increasing the active area and charge transfer ability, such materials include LSF, LSC, LSCF, SSC, BSCF etc [50].

Theoretically the cathode performance can be estimated by considering the basic materials properties. Such key properties include the electronic conductivity $\left(\sigma_{\mathrm{e}}\right)$, ionic conductivity $\left(\sigma_{\mathrm{i}}\right)$, oxygen surface exchange rate $\left(\mathrm{k}_{\mathrm{s}}\right)$, oxygen surface diffusion coefficient $\left(D_{0}\right)$, as well coefficient of thermal expansion coefficient (CTE). A perfect cathode is supposed to have high $\sigma_{e}$, and $\sigma_{i}$, large $k_{s}$ and $D_{0}$, and a compatible CTE with the electrolyte. A summary of the most used cathode materials is provided in Table 2.6.

\begin{tabular}{|c|c|c|c|c|c|c|c|}
\hline Cathode & Composition & $\begin{array}{c}\sigma_{\mathrm{e}} \\
\mathrm{S} \mathrm{cm}^{-1}\end{array}$ & $\begin{array}{c}\mathrm{k}_{\mathrm{s}} \\
\mathrm{cmS}^{-1}\end{array}$ & $\begin{array}{c}\mathrm{D}_{\mathrm{o}} \\
\mathrm{cm}^{2} \mathrm{~S}^{-1}\end{array}$ & $\begin{array}{c}\sigma_{\mathrm{i}} \\
\mathrm{S} \mathrm{cm}^{-1}\end{array}$ & $\begin{array}{c}\text { CTE } \\
\text { ppm 1/K }\end{array}$ & Ref \\
\hline LSM & $\mathrm{La}_{0.8} \mathrm{Sr}_{0.2} \mathrm{MnO}_{3}$ & 175 & $10^{-8}$ & $10^{-12}$ & $10^{-7}$ & $11-12$ & 53,55 \\
\hline LSC & $\mathrm{La}_{0.6} \mathrm{Sr}_{0.4} \mathrm{CoO}_{3}$ & 1000 & $10^{-5}$ & $10^{-7}$ & 0.22 & $22-26$ & 54,55 \\
\hline LSF & $\mathrm{La}_{0.6} \mathrm{Sr}_{0.4} \mathrm{FeO}_{3}$ & 158 & & & 0.004 & 12.8 & 56,57 \\
\hline $\mathrm{SSC}$ & $\mathrm{Sm}_{0.5} \mathrm{Sr}_{0.5} \mathrm{CoO}_{3}$ & $10^{3}$ & $10^{-4}$ & $10^{-6}$ & $>0.1$ & $19-22$ & 58 \\
\hline LSCF & $\mathrm{La}_{0.6} \mathrm{Sr}_{0.4} \mathrm{Co}_{0.8} \mathrm{Fe}_{0.2} \mathrm{O}_{3}$ & $10^{2}$ & $10^{-5}$ & $10^{-7}$ & 0.023 & $18-22$ & 59,60 \\
\hline $\mathrm{LSCF}$ & $\mathrm{La}_{0.6} \mathrm{Sr}_{0.4} \mathrm{Co}_{0.2} \mathrm{Fe}_{0.8} \mathrm{O}_{3}$ & 83 & $10^{-6}$ & $10^{-8}$ & 0.08 & 14.8 & 57 \\
\hline $\mathrm{BSCF}$ & $\mathrm{Ba}_{0.8} \mathrm{Sr}_{0.2} \mathrm{Co}_{0.8} \mathrm{Fe}_{0.2} \mathrm{O}_{3}$ & 25.4 & $10^{-3}$ & $10^{-4}$ & 0.88 & $19-23$ & 61 \\
\hline
\end{tabular}

Table 2.6 Basic properties of common SOFC cathode materials

From the Table 2.6 it can be seen that although LSM has sufficiently high electronic conductivity; but the oxygen ion conductivity is poor. Therefore LSM/YSZ mixture needs to be adopted in order to achieve both the electron and ion conductivity. MIEC such as LSC and BSCF exhibits similar electronic conductivity but with much high ionic conductivity compared with LSM, which make them suitable for using at lower temperature range. However, there are several issues need further consideration: 
1) Thermal stability. The Co rich compounds are often unstable at high temperatures, for example, BSCF will subject to $\mathrm{CO}_{2}$ poison which gives $\mathrm{BaCO}_{3}$ impurities [62]. Decomposition of LSC at high temperature was also reported. Insulating secondary phase such as $\mathrm{La}_{2} \mathrm{O}_{3}$ was found, which will severely affect the cell performance and stability [63].

2) Materials mismatch. Such Co rich compounds can react with YSZ at high temperature which yields secondary phase, such as $\mathrm{La}_{2} \mathrm{Zr}_{2} \mathrm{O}_{7}$ or $\mathrm{SrZrO}_{3}$ [63]. The big CTE mismatch will also inhabit sintering these materials on YSZ electrolyte. Therefore ceria based electrolyte or ceria buffer-YSZ electrolyte structure needs to be adopted for solving such problems.

\section{Microstructure Optimizing}

It has been well recognized that electrode microstructure is vital to the cell performance. The optimizing methodology should be adjusted for different cathode reaction mechanisms. Figure 2.6 shows the oxygen reduction reaction pathways for LSM/YSZ and MIEC (LSCF as example) cathode [50, 64], in which the active reaction zone is labeled in red.
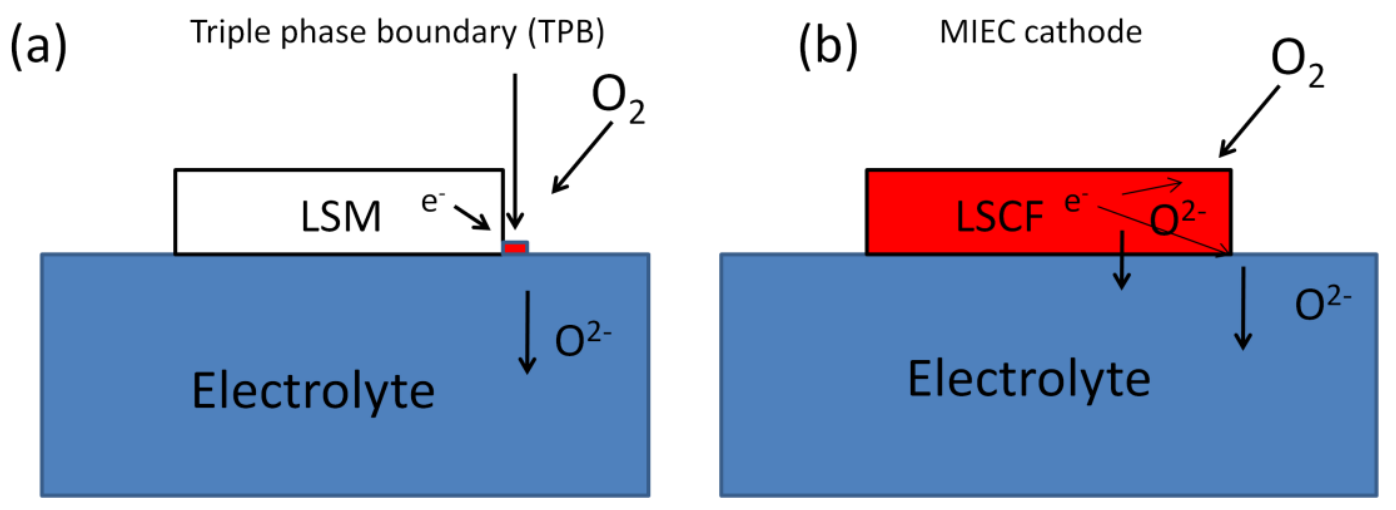

Figure 2.6 Different oxygen reduction pathways for (a) LSM/YSZ and (b) MIEC cathode

For the LSM/YSZ cathode, the reaction was limited at the so called triple phase boundary where LSM, YSZ and $\mathrm{O}_{2}$ meet. Therefore, maximizing the TPB sites should be emphasized. Such effort would include forming more intimate connections between LSM and YSZ; increasing the gas/solid interface area etc. It should be note the TPB needs to be percolated in order to fulfill the basic reaction requirements, which requires fine microstructure optimization. 
For the MIEC cathode, the ion conductivity of the cathode material should be sufficiently high. As a result, the oxygen ion can be transported through the bulk as well as along the surface. The whole surface of the cathode then can be considered as the active region. In order to enhance the performance of such MIEC cathode, maximizing the total surface area and improving the charge transportation property will be necessary.

Such microstructure optimizing can be realized either by materials synthesis or cathode fabrication technology. For the materials synthesis, nanomaterials are employed owing to their high surface area. Various methods on the SOFC cathode nanomaterials have been reported such as wet chemistry, self assembly, sol gel and molten salt etc [6568]. The main challenge is that high temperature $\left(>500^{\circ} \mathrm{C}\right)$ causes agglomeration and sintering of normal nanoparticles. This is characterized by grain growth by coalescence and porosity changes, giving material instability above $500^{\circ} \mathrm{C}$. On the other hand, anovel cathode fabrication method such as infiltration/impregnation was adopted, although the process became complex [69].

\subsection{Summary:}

In this chapter, the details of SOFC operation principle were presented. The materials and microstructure requirements of each component were discussed. The interaction between the Ni-YSZ anode and the trace impurities in coal derived syngas were reviewed. It is found that one solution of minimizing such interaction is developing intermediate temperature SOFC. The effort of current efforts of lowing SOFC temperature was then briefly discussed. 


\section{References for Chapter 2:}

[1] NETL, Fuel Cell Handbook, 7th ed., 2004

[2] R.OHayre, S.W.Cha, W.Colella and F.B.Prinz, Fuel Cell Fundamentals, Chapter 8, 244, Wiley, New York (2005)

[3] https://www.ntt-review.jp/archive/ntttechnical.php?contents=ntr200910sf3.html

[4] J.W.Yan, H.Matsumoto, M. Enoki and T.Ishihara, Electrochemical and Solid-State Letters, 2005, 8, 389

[5] R. O'Hayre, S. W. Cha, W. Colella and F. B. Prinz, Fuel Cell Fundamentals, Chapter 8, 247, Wiley, New York (2005)

[6] S. McIntosh and R. J. Gorte, Chem. Rev., 2004, 104, 4845

[7] S. P. Simner, J. P. Shelton, M. D. Anderson and J. W. Stevenson, Solid State Ionics, $2003,161,11$

[8] K. Bin Yooa and G. M. Choi, J. Eur. Ceram. Soc., 2007, 27, 4211

[9] F. Tietz, V.A.C. Haanappel, A. Mai, J. Mertens and D. Stöver, J. Power Sources, 2006, 156, 20

[10] R. O. H'ayre, S.W.Cha, W. Colella and F. B.Prinz, Fuel Cell Fundamentals, Chapter 8, 245, Wiley, New York (2005)

[11] Y. J. Leng, S. H. Chan S. P. Jiang and K. A. Khor, Solid State Ionics, 2004, 170, 9

[12] C. Brahima, A. Ringuedéa, E. Gourbaa, M. Cassira, A. Billardb and P. Brioisb, J. Power Sources, 2006, 156, 45

[13] P. G. Keech, D. E. Trifan and V. I.Birss, J. Electrochem. Soc., 2005, 152, A645

[14] H. Kurokawa, L.Yang, C. P. Jacobson, L. C. De Jonghe and S. J. Visco, J. Power Sources, 2007, 164, 510

[15] C. Higman and M. van der Burgt, Gasification, Elsevier, 2003 
[16] J. Ratafia-Brown, L. Manfredo, J. Hoffmann and M. Ramezzan, Major Environmental Aspects of Gasification-Based Power Generation Technologies, Final Report, U.S. Department of Energy, 2002

[17] J. P. Trembly, R. S. Gemmen and D. J. Bayless, J. Power. Sources, 163, 2007, 986

[18] G. N. Krishnan, Effect of Coal Contaminants on Solid Oxide Fuel Cell System Performance and Service Life, Technical Progress Report 1, SRI International, Morgantown, 2006

[19] M. Gong, X. Liu, J. Trembly and C. Johnson, J. Power Sources, 168, 2007, 289

[20] J. P. Trembly, A. I. Marquez, T. R. Ohrn and D. J. Bayless, J. Power Sources, 158, 2006, 263

[21] G.N. Krishnan, P. Jayaweera, K. Lau and A. Sanjurjo Effect of Coal Contaminants on Solid Oxide Fuel Cell System Performance and Service Life, Technical Progress Report 3, SRI International, Morgantown, 2006

[22] J. P. Trembly, R. S. Gemmen and D.J. Bayless, J. Power Sources. 169, 2007, 347

[23] G. N. Krishnan, P. Jayaweera, K. Lau and A. Sanjurjo, Effect of Coal Contaminants on Solid Oxide Fuel Cell System Performance and Service Life, Technical Progress Report 2, SRI International, Morgantown, 2006

[24] C. C. Xu, M. Y Gong, J. W. Zondlo, X. B Liu and H. O. Finklea, J. Power Sources. $195,2010,2149$

[25] K. Haga, Y. Shiratori, K. Ito and K. Sasaki, J. Electrochem. Society, 155, 2008, 1233

[26] J. P. Trembly, R. S. Gemmen and D. J. Bayless, J. Power Sources, 171, 2007, 818

[27] G. N. Krishnan, Effect of coal contaminants on SOFC cell performance, Proceedings of the 8th Annual SECA Review Workshop, San Antonio, TX, 2007 
[28] C. A. Coyle, O. A. Marina, E. C. Thomsen, D. J. Edwards, C.D. Cramer, G. W. Coffey and L. R. Pederson, J. Power Sources, 173, 2009, 730

[29] G.N. Krishnan, P. Jayaweera and J. Perez, Effect of Coal Contaminants on Solid Oxide Fuel Cell System Performance and Service Life, Technical Progress Report 4, SRI International, Morgantown, 2006

[30] O.A.Marina, L.R. Pederson, D.J. Edwards, C.W. Coyle, J. Templeton, M. Engelhard, Proceedings of the 8th Annual SECA Workshop, San Antonio, TX, 2007

[31] M. Zhi, F. N. Cayan, I. Celik, R. Gemmen, S. R. Pakalapati and N. Q. Wu, Fuel Cells, 2010, 10, 174

[32] J.P. Trembly, R. Gemmen, D.J. Bayless, Proceedings of the 5th International Fuel Cell Science, Engineering and Technology Conference, New York, NY, 2007

[33] M. J. Zhi, X. Q. Chen, H. Finklea, I. Celik, N. Q. Wu, J. Power Sources, 183, 2008, 485

[34] O.Marina, L.R. Pederson, D. J. Edwards, C.W. Coyle, J. Templeton and M. Engelhard, Proceedings of the 9th Annual SECA Workshop, Pittsburg, PA, 2008

[35] C. C. Xu, J. W. Zondlo, H. O. Finklea, O. Demircan, M. Y. Gong and X. B. Liu, J. Power Sources,193, 2009, 739

[36] C. C. Xu, J. W. Zondlo, M. Y. Gong and X. B. Liu, J. Power Sources,196, 2011, 116

[37] O. Demircan, C. C. Xu, J. W. Zondlo and H. O. Finklea, J. Power Sources, 194, 2009,214

[38] O. Demircan, W. Zhang, C. C. Xu, J. W. Zondlo and H. O. Finklea, J. Power Sources,195, 2010, 3091 
[39] O. A. Marina , C. A. Coyle, E. C. Thomsen, D. J. Edwards, G. W. Coffey, L.R. Pederson, Solid State Ionics, 181, 2010, 430

[40] W. Lu, X. Sun, L.R. Pederson, O. A. Marina, M. A. Khaleel, J. Power Sources, 195, 2010,7140

[41] H. Guo, G. Iqbal and B. Kang, Int. J. Appl. Ceram. Technol in press

[42] M. Y. Gong, D. Bierschenk, J. Haag, K.R. Poeppelmeier, S. A. Barnett, C. C Xu, J. W. Zondlo and X. B. Liu, , J. Power Sources,195, 2010, 4013

[43] S.A. Benson, T.A. Erickson, C.J. Zygarlicke, C. A. O'Keefe, K.A. Katrinak, S.E. Allen, D.J. Hassett and W.B. Hauserman, Proceedings of the Advanced Coal-Fired Power Systems 96 Review Meeting, Morgantown,West Virginia, 1996

[44] H. J. Goldsmidt and M.J. Walker, Journal of Applied Crystallography. 2 1969, 273

[45] S. E. Veyo, Evaluation of Fuel Impurity Effects on Solid Oxide Fuel Cell Performance, Final Technical Report, Westinghouse Electric Company, Pittsburgh, 1998.

[46] G. N. Krishnan, Advanced Coal-Fired Power Systems '96 Review Meeting, 1996, Morgantown, WV, 1996

[47] K.V. Jenson, R.Wallenberg, I. Chorkendorff and M. Mogensen, Solid State Ionics, 160, (2003), 27

[48] K. Gerdes, J. Trembly and R. Gemmen, Proceedings of the Coal based Fuel Cell Technology:Status, Needs and Future Applications, Morgantown, WV, 2007

[49] F. N. Cayan, M. J. Zhi, S. R. Pakalapati, I. Celik, N. Q. Wu and R. Gemmen, J. Power Sources, 185, 2008, 595

[50] S. B. Adler, Chem. Rev., 104, 2004, 4791 
[51] K. Yamahara, T. Sholklapper, C. P. Jacobson, S. J. Visco, and L. C. De Jonghe, Solid State Ionics, 176, 2005, 1359

[52] Q. N. Minh, J. Am. Ceram. Soc., 76, 1993, 563

[53] J. W. Yan, H. Matsumoto, M. Enoki and T.Ishihara, Electrochemical and Solid-State Letters, 8, 2005, 389

[54] N. Q. Minh and T. Takahashi, Science and Technology of Ceramic Fuel Cells, Elsevier, Amsterdam, Netherlands, 1995

[55] S. C. Singhal and K. Kendall, High Temperature Solid Oxide Fuel Cells:

Fundamentals, Design and Applications, Elsevier Advanced Technology, UK, 2003

[56] S. P. Simner, J. F. Bonnett, N. L. Canfield, K. D. Meinhardt, J. P. Shelton, V. L. Sprenkle, and J. W. Stevenson, J. Power. Sources, 113, 20031

[57] Q. Zhu, T. Jin and Y. Wang, Solid State Ionic, 177, 2006, 1199

[58] H. Lv, Y. Wu, B. Huang, B. Zhao and K. Hu, Solid State Ionics, 177, 2006, 901

[59] R. Ciba, F. Yoshimura and Y. Sakurai, Solid State Ionics, 124, 1999, 281

[60] R. N. Basu, F. Tietz, E. Wessel, H. P. Buchkremer and D. Stover, Materials Research Bulletin, 39, 2004, 1335

[61] Z. Shao and S. M. Haile, Nature, 431, 2004, 170

[62] Z. Yáng, A. S. Harvey, A. Infortuna and L. J. Gauckler, J. Appl. Cryst., 42, 2009, 153

[63] E. Koep, C. Jin, M. Haluska, R. Das, R. Narayan, K. Sandhage, R. Snyder and M. Liu, J. Power. Sources, 161, 2006, 250

[64] Y. H. Li, R. Gemmen and X. B. Liu, J. Power. Sources, 195, 2010, 3325

[65] J. Wang, A. Manivannan and N. Q. Wu, Thin Solid Films, 2008, 517, 582 
[66] M. G. Bellino, J. G. Sacanell, D. G. Lamas, A. G. Leyva and N. E. W.de Reca, J. Am. Chem. Soc., 129, 2007, 3066

[67] J. Sacanell, A. G. Leyva, M. G. Bellino and D. G. Lamas, J. Power. Sources, 195, 2010, 1786

[68] M. Mamak, G. S. Métraux, S. Petrov, N. Coombs, G. A. Ozin, and M. A. Green, J. Am. Chem. Soc., 125, 2003, 5161

[69] J. M. Vohs and R. J. Gorte, Adv. Mater., 21, 2009, 943 


\section{Chapter 3: Degradation of Ni-YSZ Anode in $\mathrm{PH}_{3}$ Contained Coal Syngas}

\subsection{Introduction:}

The use of syngas derived from coal or biomass has received much attention in recent years. Direct utilization of coal-derived syngas as the fuel for SOFC can increase the energy efficiency and reduce the operation cost of power generation, enable the coproduction of other marketable commodities such as chemicals (e.g., hydrogen and sulfur), and provide flexibility for carbon dioxide sequestration. However, coal-derived syngas generally contains various trace impurities such as phosphorus, arsenic, mercury, selenium, vanadium, and zinc as summary in chapter 2. The SOFC anode that is operated in such impurities is subject to degradation due to the attack of the trace impurities. Among the impurities in the coal syngas, phosphorus compounds could cause the degradation of SOFC anodes which has been reviewed in the previous chapter.

In the present work, we report the electrochemical behavior of the Ni-YSZ anode operated in $\mathrm{PH}_{3}$ contained syngas. Also, we discuss the degradation mechanism of the Ni-YSZ anode in the $\mathrm{PH}_{3}$-containing syngas. The relationship of the electrochemical performance with some key parameters such as temperature, impurity concentration, DC bias is studied and the anode materials phase transfer and microstructure reconstruction are investigated. Two sets of experiments were carried out in order to address those parameters. The first set of experiments offer information about the effect of the electrical potential on the degradation behavior, and the second one is a detail investigation of the temperature and the $\mathrm{PH}_{3}$ concentration effects. Thermal dynamic calculation is carried to help understanding the experiment result. A flowchart of the research strategy is shown in Figure 3.1. 


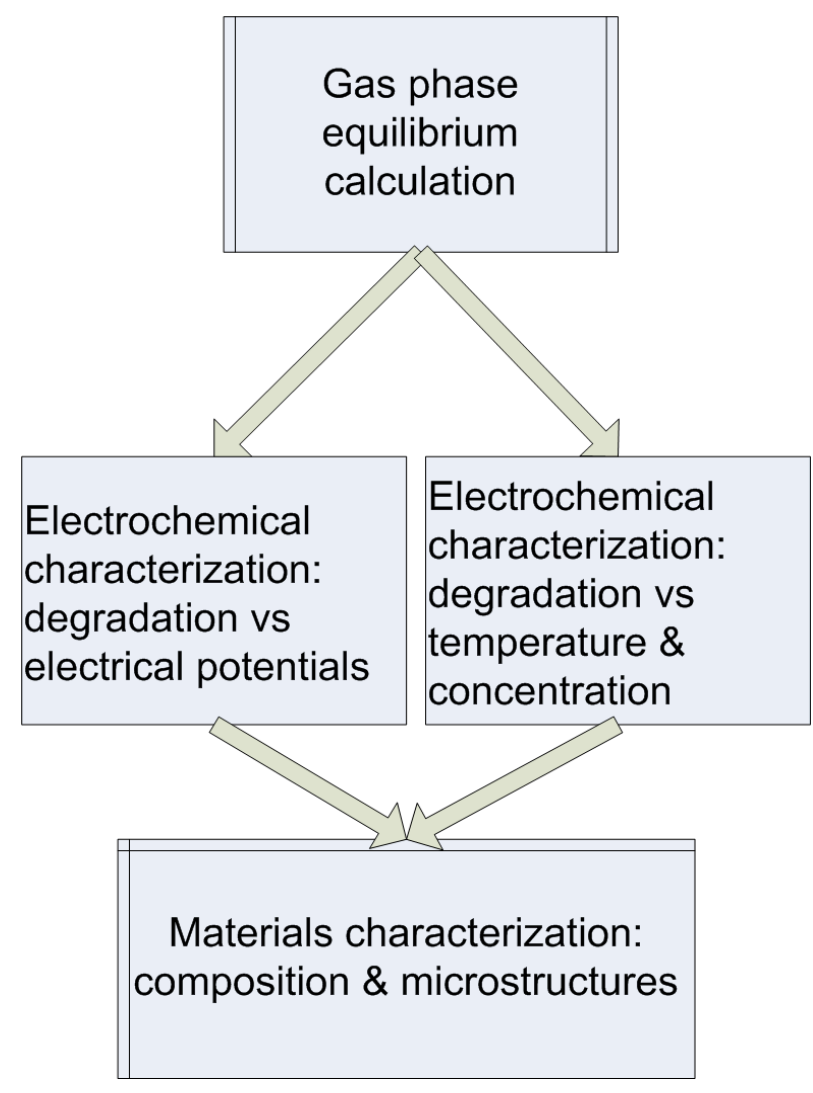

Figure 3.1 Research strategy of investigating the degradation behavior of Ni-YSZ anode in $\mathrm{PH}_{3}$ contained coal syngas

\subsection{Gas Phase Equilibrium Calculation:}

Prior to testing, thermodynamic calculations were conducted to determine the stable forms of $\mathrm{P}$ under the equilibrium conditions when $\mathrm{PH}_{3}$ co-exists with the coal syngas. In the present study, Cantera 1.7 [1], an open-source library of chemical kinetics and thermodynamic equilibrium subroutines, which is capable of solving multiphase equilibrium problems, was employed for calculations. For multiphase equilibrium computations, Cantera uses the Villars-Cruise-Smith (VCS) algorithm. This algorithm solves the stoichiometric formulation of equilibrium conditions by minimizing the total Gibbs function of the system at the specified temperature and pressure with the constraint of non-negative molar concentrations $(\mathbf{n} \geq 0)[1]$ :

$$
G(\xi)=\mathbf{n}^{\top} \boldsymbol{\mu}=\left[\mathbf{n}^{0}+\mathbf{N} \xi\right]^{\top} \boldsymbol{\mu}
$$


Here $G$ is the total Gibbs function of the mixture, $\xi$ is the extent of reaction vector, $\mathbf{n}$ is the vector of mole fractions, $\mathbf{N}$ is the stoichiometric matrix, $\boldsymbol{\mu}$ is the vector of specie chemical potentials and the superscripts ' 0 ' and ' $T$ ' stand for initial condition and transpose respectively. The details of the numerical procedure can be found in Reference [2].

The composition of the syngas used in the calculations was $30.6 \% \mathrm{H}_{2}, 30.0 \% \mathrm{CO}$, $11.8 \% \mathrm{CO}_{2}$ and $27.6 \% \mathrm{H}_{2} \mathrm{O}$. The initial $\mathrm{PH}_{3}$ concentration varied from 0 to $20 \mathrm{ppm}$. Equilibrium calculations were performed at 1 atm from 750 to $900{ }^{\circ} \mathrm{C}$. All possible forms of the species in the gas phase and/or in the condensed phase such as $\mathrm{PH}_{3}(\mathrm{~g}), \mathrm{P}_{2} \mathrm{O}_{3}(\mathrm{~g})$, $\mathrm{P}_{2} \mathrm{O}_{5}(\mathrm{~g}), \mathrm{HPO}_{2}(\mathrm{~g})$ and $\mathrm{H}_{3} \mathrm{PO}_{4}(\mathrm{l})$ were considered in the calculations. The gas phase species are assumed to obey the ideal gas law and the mixture is treated as an ideal mixture. The condensed phase species are assumed to be either stoichiometric solids or stoichiometric liquids. Thermodynamic data of these species are obtained from reference [3].

The calculations showed that $\mathrm{PH}_{3}$ was converted to $\mathrm{P}_{2} \mathrm{O}_{3}$, which was the most stable form of phosphorous species under the equilibrium conditions. The equilibrium concentrations of $\mathrm{PH}_{3}$ and $\mathrm{P}_{2} \mathrm{O}_{3}$ as a function of the initial $\mathrm{PH}_{3}$ concentration (1-20 ppm) and the system temperatures $\left(750-900^{\circ} \mathrm{C}\right)$ are shown in the phase diagram (Figure.3.2). The solid lines in Figure.3.2 represent the equilibrium concentration (ppm) of $\mathrm{P}_{2} \mathrm{O}_{3}$ and the dash lines give the equilibrium concentration (ppm) of $\mathrm{PH}_{3}$. Table 3.1 lists the equilibrium concentrations of the $\mathrm{PH}_{3}$ and $\mathrm{P}_{2} \mathrm{O}_{3}$ under the experimental condition, which is derived from Figure.1. The following conclusions were drawn from Figure.3.2 and Table 3.1:

(i). Under the equilibrium condition, the major form of phosphorous in the gas phase was $\mathrm{P}_{2} \mathrm{O}_{3}$, which indicated that most of $\mathrm{PH}_{3}$ was oxidized due to the presence of highconcentration water vapor in the fuel gas. This is in agreement with the results reported in the literature [4].

(ii). The equilibrium concentration of $\mathrm{P}_{2} \mathrm{O}_{3}$ was heavily dependent on the initial concentration of $\mathrm{PH}_{3}$ but much less dependent on the temperature in the range of 750 ${ }^{\circ} \mathrm{C}-900{ }^{\circ} \mathrm{C}$. 


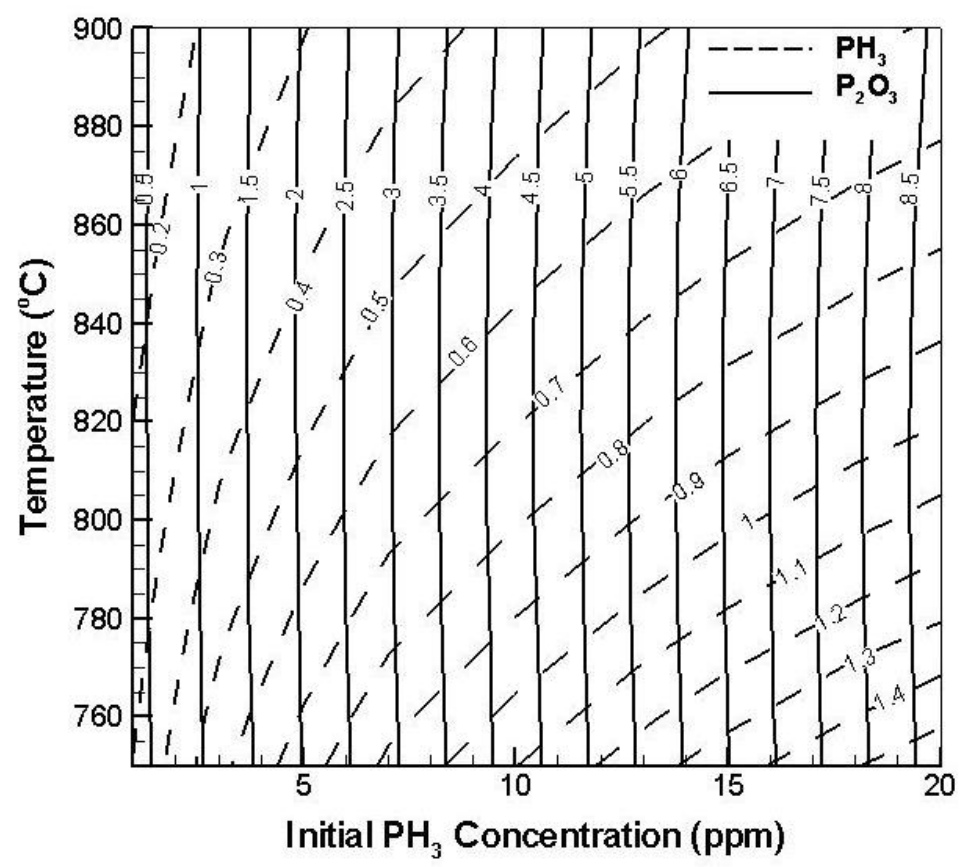

Figure 3.2 $\mathrm{P}_{2} \mathrm{O}_{3}$ and $\mathrm{PH}_{3}$ mole fractions at equilibrium, solid line represents $\mathrm{P}_{2} \mathrm{O}_{3}$ and dash line represents $\mathrm{PH}_{3}[5]$

\begin{tabular}{|c|c|c|c|c|c|}
\hline \multirow{2}{*}{$\begin{array}{c}\text { Initial } \mathrm{PH}_{3} \text { concentrations } \\
(\mathbf{p p m})\end{array}$} & \multicolumn{5}{|c|}{ Equilibrium gas concentrations (ppm) } \\
\hline & $\begin{array}{l}\text { Major Phosphorus } \\
\text { related impurities }\end{array}$ & $750^{\circ} \mathrm{C}$ & $800^{\circ} \mathrm{C}$ & $850^{\circ} \mathrm{C}$ & $900^{\circ} \mathrm{C}$ \\
\hline \multirow[b]{2}{*}{5} & $\mathrm{PH}_{3}$ & 0.76 & 0.55 & 0.40 & 0.30 \\
\hline & $\mathbf{P}_{2} \mathbf{O}_{3}$ & 2.01 & 2.06 & 2.07 & 2.03 \\
\hline \multirow[b]{2}{*}{10} & $\mathbf{P H}_{3}$ & 1.09 & 0.79 & 0.57 & 0.42 \\
\hline & $\mathbf{P}_{2} \mathbf{O}_{3}$ & 4.23 & 4.30 & 4.29 & 4.21 \\
\hline \multirow[b]{2}{*}{20} & $\mathbf{P H}_{3}$ & 1.58 & 1.73 & 0.82 & 0.61 \\
\hline & $\mathbf{P}_{2} \mathbf{O}_{3}$ & 8.76 & 8.82 & 8.79 & 8.63 \\
\hline
\end{tabular}

Table 3.1 $\mathrm{P}_{2} \mathrm{O}_{3}$ and $\mathrm{PH}_{3}$ concentration at given experimental conditions

It is notable that the calculation is based on the equilibrium condition. It proves that the convention of phosphine to phosphorous oxide is thermodynamic feasible although the real concentrations of $\mathrm{PH}_{3}$ and $\mathrm{P}_{2} \mathrm{O}_{3}$ admitted to the anode are still unknown due to the lack of the in-situ gas composition measurements. 


\subsection{Degradation of Ni-YSZ Anode in $\mathrm{PH}_{3}$ Contained Coal Syngas: Effect of the Electrical Bias:}

\subsubsection{Experimental Methods}

A symmetrical Ni-YSZ/YSZ/Ni-YSZ half cell was used in our study, where YSZ stands for $8 \mathrm{~mol} \%$ yttria stabilized zirconia. Figure 3.3 shows the configuration of the half cell. A $150 \mu \mathrm{m}$ thick YSZ disc was used as the electrolyte. The $50 \mu \mathrm{m}$ thick $\mathrm{NiO} / \mathrm{YSZ}$ cermet (50/50) was screen-printed on the two sides of the YSZ disc as the working and the counter electrodes (WKG and CTR). A Pt ring (approximate 1mm wide) was painted near the edge of the electrolyte disc on the WKG side as the reference electrode (REF). The separation between the REF and the WKG was about $2 \mathrm{~mm}$, which was large enough to ensure the measurements accuracy [6]. The Ni meshes in contact with each Ni-YSZ electrode were used as the current collectors.

The half cell was placed at the center of a quartz tube inside a tube furnace. A thermocouple was placed adjacent to the half cell to monitor the temperature. Before testing, the electrode was heated to $650^{\circ} \mathrm{C}$ at $1{ }^{\circ} \mathrm{C} / \mathrm{min}$ in $\mathrm{N}_{2}$, and then $\mathrm{H}_{2}$ was introduced till the cell temperature reached $900{ }^{\circ} \mathrm{C}$ to reduce the $\mathrm{NiO}$ to be $\mathrm{Ni}$. The tube was fed with three types of fuel gases: (i) $\mathrm{H}_{2}+3 \% \mathrm{H}_{2} \mathrm{O}$, (ii) simulated clean coal syngas $\left(30.6 \% \mathrm{H}_{2}, 30 \%\right.$ $\mathrm{CO}, 11.8 \% \mathrm{CO}_{2}$, and $27.6 \% \mathrm{H}_{2} \mathrm{O}$ ) as shown in Table 3.1, and (iii) simulated coal syngas containing $20 \mathrm{ppm} \mathrm{PH}_{3}$. The $\mathrm{PH}_{3}$ impurity was introduced to the tube with a $1000 \mathrm{ppm}$ $\mathrm{PH}_{3} / \mathrm{N}_{2}$ gas mixture. The total flow rate was controlled from $150 \mathrm{sccm}$ to $200 \mathrm{sccm}$ (standard cubic centimeter per minute) by the mass flow controllers. A humidity bottle was employed to achieve the desired water vapor partial pressure. The DC load was applied to the working electrode versus the counter electrode. Two cables were connected to the working electrode and the reference electrode to obtain electrochemical impedance spectroscopy (EIS). The impedance spectra were measured with Solartron SI 1260 impedance/grain-phase analyzer at $\mathrm{AC}$ amplitude of $10 \mathrm{mV}$ with the $\mathrm{AC}$ frequency from

$300 \mathrm{kHz}$ to $0.1 \mathrm{~Hz}$. The impedance data were fitted by the commercial $\mathrm{Zview}^{\odot}$ software to obtain the parameters in the simulated equivalent circuit. 


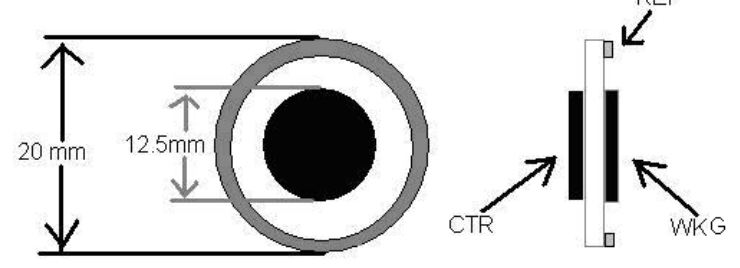

Figure 3.3 Configuration of the half cell

\begin{tabular}{|l|l|}
\hline Component & Composition (vol. \%) \\
\hline $\mathrm{H}_{2}$ & 30.6 \\
\hline $\mathrm{CO}$ & 30.0 \\
\hline $\mathrm{CO}_{2}$ & 11.8 \\
\hline $\mathrm{H}_{2} \mathrm{O}$ & 27.6 \\
\hline $\mathrm{PH}_{3}$ & $20 \mathrm{ppm}$ \\
\hline
\end{tabular}

Table 3.2 Coal syngas composition used in experiments

The morphology of the Ni-YSZ anode was examined with Hitachi S-4700 scanning electron microscope (SEM). The crystal structure of the anode was determined with Panalytical X-ray diffractometer (XRD) equipped with a thin film stage. The chemical status and chemical composition of the anode was characterized with Omicron ESCA PROBE X-ray photoelectron spectroscopy (XPS). XPS was performed with a monochromatic $\mathrm{Al} \mathrm{K \alpha}$ radiation $(1486.6 \mathrm{eV})$ with an operating power of $300 \mathrm{~W}$.

\subsubsection{Result and Discussion:}

\subsubsection{Electrochemical Measurement}

A half cell was exposed to different fuel gases at $900^{\circ} \mathrm{C}$. A $0.7 \mathrm{~V} \mathrm{DC}$ bias was applied between the working electrode and the counter electrode to drive the current through the cell. The WKG electrode bias was positive to drive the oxidation of hydrogen to water. The CTR electrode was simultaneously reducing water vapor to hydrogen. The plot of the DC current as function of the operating time was recorded (Figure 3.4). The current density in Figure 3.4 is $0.75 \mathrm{~A} / \mathrm{cm}^{2}$. The cell was initially 
exposed to wet $\mathrm{H}_{2}$ gas $\left(97 \% \mathrm{H}_{2}+3 \% \mathrm{H}_{2} \mathrm{O}\right)$ for 4 hours. The feed gas was then switched

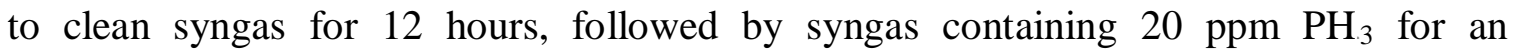
additional 12 hours. It can be seen from Figure 3.4 that the current remained almost constant in the $\mathrm{H}_{2}$ gas. When the fuel gas was switched to simulated clean syngas, the current dropped immediately. Although the current was smaller under the clean syngas condition, the current was very stable. When 20 ppm $\mathrm{PH}_{3}$ was introduced into the syngas, the current decreased steadily with time, indicating that the cell was undergoing degradation and that the total resistance (ohmic, polarization, mass transfer) of the cell increased.

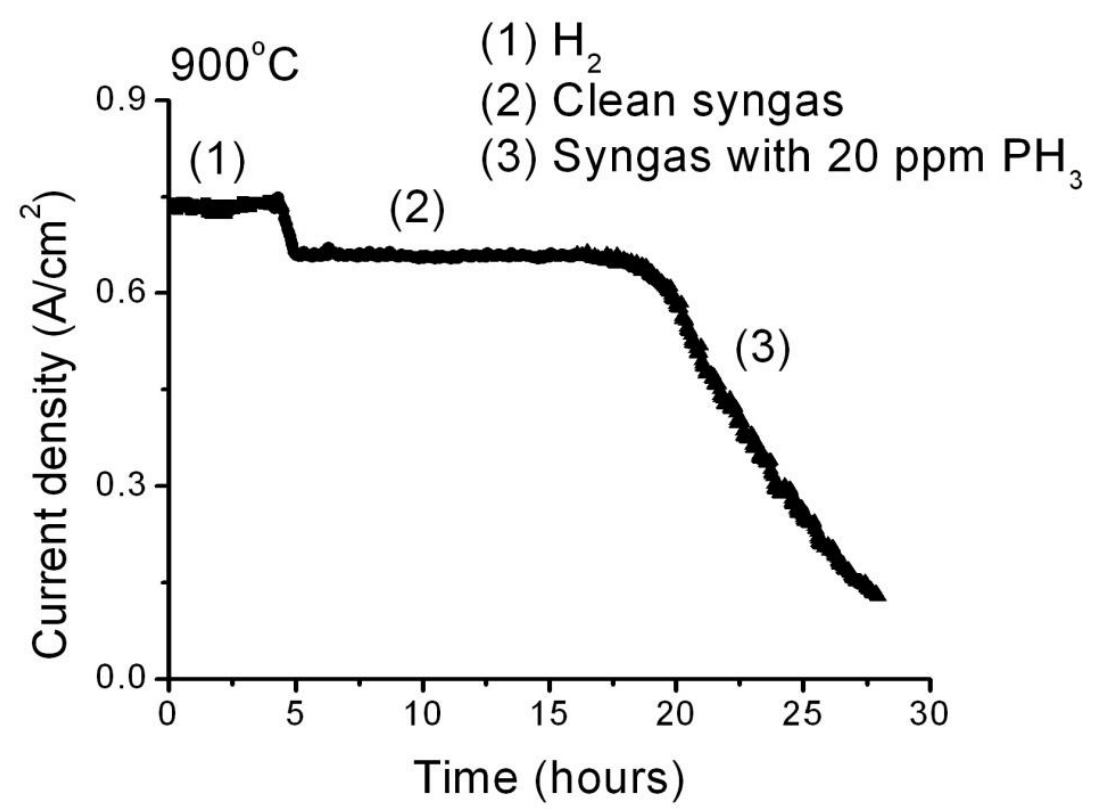

Figure 3.4 Effect of the fuel gas on the DC current (driven by the DC bias of $0.7 \mathrm{~V}$ )

To understand the underlying degradation mechanism of the half cell in the $\mathrm{PH}_{3}$ containing syngas, electrochemical impedance measurements were performed. Two sets of impedance data were obtained. One set was acquired at the open circuit (no DC current between the working electrode and the counter electrode). The other set was acquired at the loading potential of $+0.7 \mathrm{~V}$ (WKG electrode vs. CTR electrode). The impedance data were collected between the working electrode and the reference electrode every 4 hours during exposure to $\mathrm{PH}_{3}$ gas, and also during exposure to wet hydrogen and clean syngas. Figure 3.5 shows the Nyquist plots of impedance. Two arcs were observed in the Nyquist plots of impedance in Figure 3.5. The intercept of the high frequency arc is the ohmic 
series resistance of the cell. It is low $\left(0.2 \mathrm{Ohm} \mathrm{cm}^{2}\right)$ and within experimental uncertainty invariant during the successive gas exposures. The impedance plot did not change after the half cell was exposed to the clean syngas for 12 hours, which implies that the cells were not subject to any noticeable degradation in the presence of the clean syngas. However, after the 20 ppm $\mathrm{PH}_{3}$ was introduced into the reactant gas, the total polarization resistance of the electrode increased with the exposure time.

\section{(a)}

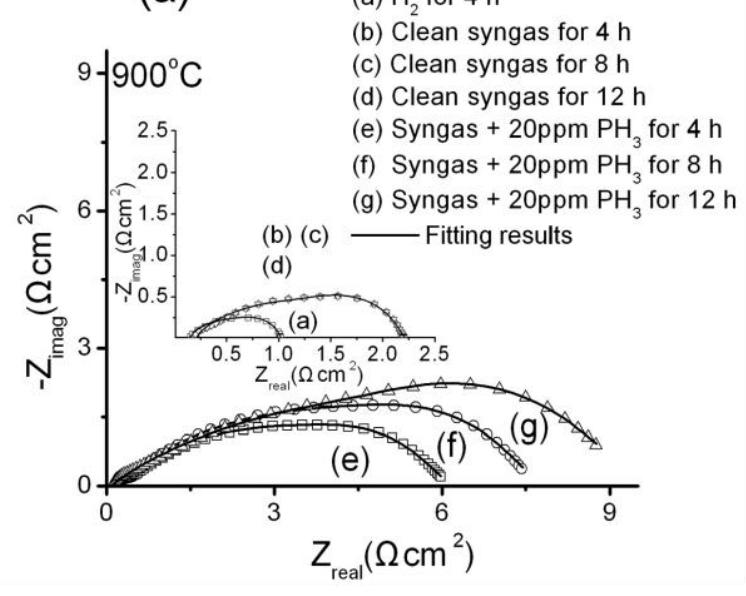

(b)

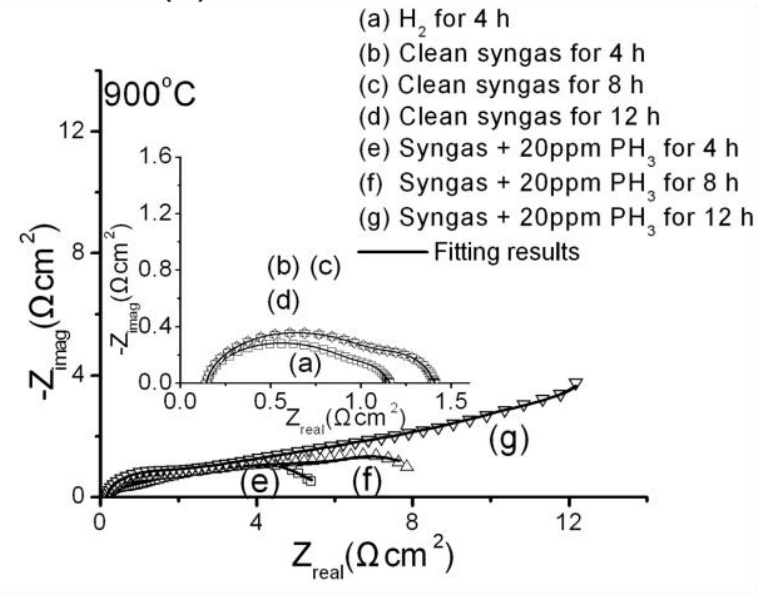

Figure 3.5 Nyquist plot of impedance obtained from the half cell at $900^{\circ} \mathrm{C}$; (a) under the open circuit condition; (b) at $+0.7 \mathrm{~V}$ potential applied between the working electrode and the counter electrode.

In Figure 3.5, the arc at the high frequency regime (characteristic frequency ca. $10^{4} \mathrm{~Hz}$ ) is attributed to the impedance of the YSZ electrolyte, because the characteristic 
frequency of the YSZ electrolyte in YSZ-based electrochemical cells usually is larger than $10^{4} \mathrm{~Hz}[7,8]$. The arc at the low frequency regime (characteristic frequency ca. $10^{2}$ $\mathrm{Hz})$ is attributed to the electrode reaction. We propose that the equivalent circuit model in Figure 3.6 to explain our experimental data. In this model, $\mathrm{L}$ is defined as the inductance associated with the long leads from the impedance system to the half cell. $\mathrm{C}$ is the geometrical capacitance. $R_{e}$ represents the resistance of the electrolyte and the contact resistance of the whole circuit. $R_{p}$ is the charge transfer resistance that controls the Faradaic current. $\mathrm{CPE}_{\mathrm{p}}$ is a double-layer constant phase element. The impedance of $\mathrm{CPE}$ can be expressed by

$$
Z_{C P E}=1 / Y(j \omega)^{n}
$$

where $\mathrm{Y}$ is the pseudo-capacitance, $\omega$ is radial frequency $(\omega=2 \pi \mathrm{f})$ and $\mathrm{n}$ is the exponent constant. $\mathrm{W}_{\text {diff }}$ is the Warburg diffusion element that reflects the gas diffusion to the electrode. The Warburg impedance can be expressed by

$$
Z_{W}=R_{w} \cdot \tanh (j Y \omega)^{0.5} /(j Y \omega)^{0.5}
$$

$R_{w}$ is derived from the Warburg diffusion element and represent the diffusion resistance.

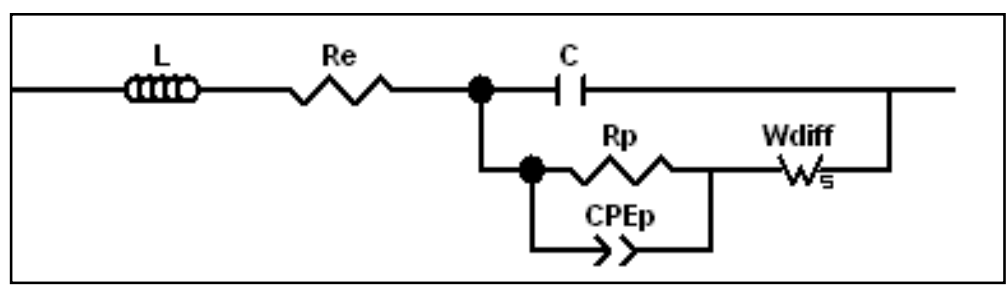

Figure 3.6 Equivalent circuit models of the impedance spectra

The low frequency arc was pulled down toward the $Z_{\text {real }}$ axis when either the $\mathrm{H}_{2}$ concentration or the DC bias increased (Figure. 3.5). As the DC bias increased from 0 to $+0.3 \mathrm{~V}$, the charge transfer resistance $R_{p}$ decreased while the diffusion resistance remained almost constant. Obviously, this trend suggests that $R_{p}$ is governed by an electrochemical reaction, because only the impedance corresponding to charge transfer or an electrochemical reaction can be reduced by an applied bias [7,9] as indicated by Butler-Volmer equation [10]. It is not surprising that the gas diffusion remains constant, as indicated by the constant value of the Warburg element, because diffusion is 
dependent on the concentration gradient, as determined by the partial pressure of the reactants $\mathrm{H}_{2}$ or $\mathrm{H}_{2} \mathrm{O}$ in the gas phase and in the reaction zone next to the electrolyte.

Table 3.3 lists the values of the circuit elements at the different conditions. The values of $R_{p}$ and $R_{w}$ under different conditions are also graphically compared in Figure 3.7. The $R_{p}$ and $R_{w}$ values for the two sets of impedance data are normalized with respect to the initial values in wet hydrogen so that the relative increase in these parameters can be compared. Although both $R_{p}$ and $R_{w}$ in the clean syngas are larger than those in the wet $\mathrm{H}_{2}$ gas, both $R_{p}$ and $R_{w}$ remain constant during the exposure time either in the clean syngas or in the wet $\mathrm{H}_{2}$ gas. However, both the charge transfer resistance $\left(R_{p}\right)$ and the diffusion resistance $\left(R_{w}\right)$ increase with time during exposure to the $\mathrm{PH}_{3}$-containing syngas. This suggests that the incorporation of phosphorus impurity into the electrode not only impedes the charge transfer but also blocks the channels of gas diffusion. The normalized diffusion resistance increases faster than the charge transfer resistance. The impedance plot after 12 hours of exposure to the P-containing syngas at a loading of +0.7 $\mathrm{V}$ (Figure 3.5 (b)) shows a linear tail at low frequencies, implying that the impedance is dominated by the diffusion control of the reactant gases. This observation suggests that the porous microstructure of the electrode is being destroyed. Furthermore, both the charge transfer resistance and the diffusion resistance under the loading potential are larger the equivalent resistances at the open circuit. We hypothesize that the applied electric field accelerates the incorporation of $\mathrm{P}$ into the electrode, which deteriorates the degradation of the electrode operated in the impurities contained syngas. 


\begin{tabular}{|c|c|c|c|c|c|c|c|c|c|c|}
\hline \multirow[t]{2}{*}{ Elements } & \multicolumn{5}{|c|}{ Open circuit } & \multicolumn{5}{|c|}{ Loaded } \\
\hline & $\mathrm{H}_{2}$ & $\begin{array}{c}\text { Clean } \\
\text { Syngas }\end{array}$ & $\begin{array}{l}\text { Syngas + } \\
20 \mathrm{ppm} \\
\mathrm{PH}_{3} 4 \mathrm{hh}\end{array}$ & $\begin{array}{c}\text { Syngas + } \\
20 \mathrm{ppm} \\
\mathrm{PH}_{3} 8 \mathrm{~h}\end{array}$ & $\begin{array}{c}\text { Syngas + } \\
20 \mathrm{ppm} \\
\mathrm{PH}_{3} 12 \mathrm{~h}\end{array}$ & $\mathrm{H}_{2}$ & $\begin{array}{l}\text { Clean } \\
\text { Syngas }\end{array}$ & $\begin{array}{c}\text { Syngas }+20 \\
\text { ppm } \\
\mathrm{PH}_{3} 4 \mathrm{~h}\end{array}$ & $\begin{array}{c}\text { Syngas + } \\
20 \mathrm{ppm} \\
\mathrm{PH}_{3} 8 \mathrm{~h}\end{array}$ & $\begin{array}{c}\text { Syngas + } \\
20 \mathrm{ppm} \\
\mathrm{PH}_{3} 12 \mathrm{~h}\end{array}$ \\
\hline $\mathrm{L}(\mathrm{H})$ & $6.5 \mathrm{E}-8$ & $6.6 \mathrm{E}-8$ & $6.42 \mathrm{E}-6$ & $5.90 \mathrm{E}-8$ & $9.15 \mathrm{E}-8$ & $6.22 \mathrm{E}-8$ & $6.87 \mathrm{E}-8$ & $5.79 \mathrm{E}-8$ & $2.08 \mathrm{E}-7$ & $1.14 \mathrm{E}-7$ \\
\hline $\mathrm{R}_{\mathrm{e}}\left(\Omega \mathrm{cm}^{2}\right)$ & 0.18 & 0.15 & 0.16 & 0.18 & 0.19 & 0.20 & 0.21 & 0.23 & 0.24 & 0.24 \\
\hline $\mathrm{C}(\mathrm{F})$ & $1.7 \mathrm{E}-5$ & $3.9 \mathrm{E}-6$ & $3.1 \mathrm{E}-6$ & $7.63 \mathrm{E}-6$ & $1.76 \mathrm{E}-5$ & $6.0 \mathrm{E}-6$ & $7.1 \mathrm{E}-6$ & $9.5 \mathrm{E}-6$ & $4.6 \mathrm{E}-5$ & $6.1 \mathrm{E}-5$ \\
\hline$R_{p}\left(\Omega \mathrm{cm}^{2}\right)$ & 0.61 & 0.87 & 5.01 & 6.12 & 7.11 & 0.93 & 1.024 & 5.226 & 8.356 & 15.74 \\
\hline CPE -Y(S.s $\left.{ }^{n}\right)$ & $3.8 \mathrm{E}-3$ & $6.1 \mathrm{E}-3$ & $1.41 \mathrm{E}-2$ & $1.7 \mathrm{E}-2$ & $3.2 \mathrm{E}-2$ & $1.7 \mathrm{E}-3$ & $2.8 \mathrm{E}-3$ & $2.31 \mathrm{E}-2$ & $4.54 \mathrm{E}-2$ & $6.94 \mathrm{E}-2$ \\
\hline CPE-n & 0.666 & 0.581 & 0.63 & 0.640 & 0.658 & 0.575 & 0.337 & 0.397 & 0.353 & 0.384 \\
\hline$R_{w}\left(\Omega \mathrm{cm}^{2}\right)$ & 0.331 & 0.70 & 0.99 & 1.511 & 2.522 & 0.124 & 0.259 & 1.092 & 2.375 & 6.901 \\
\hline $\begin{array}{l}\text { W-Y } \\
\left(S \cdot s^{n}\right)\end{array}$ & $1.5 \mathrm{E}-3$ & $5.0 \mathrm{E}-3$ & $1.1 \mathrm{E}-1$ & $2.2 \mathrm{E}-1$ & $5.0 \mathrm{E}-1$ & $1.3 \mathrm{E}-3$ & $2.8 \mathrm{E}-3$ & $2.7 \mathrm{E}-1$ & $4.8 \mathrm{E}-1$ & $9.1 \mathrm{E}-1$ \\
\hline W-n & 0.5 & 0.5 & 0.5 & 0.5 & 0.5 & 0.5 & 0.5 & 0.5 & 0.5 & 0.5 \\
\hline$\chi^{2}$ & $1.8 \mathrm{E}-5$ & $1.7 \mathrm{E}-5$ & $2.8 \mathrm{E}-5$ & $3.3 \mathrm{E}-5$ & $2.9 \mathrm{E}-5$ & $5.8 \mathrm{E}-6$ & $2.4 \mathrm{E}-6$ & $8.5 \mathrm{E}-6$ & $4.2 \mathrm{E}-6$ & $3.2 \mathrm{E}-6$ \\
\hline
\end{tabular}

Table 3.3 Parameters of the equivalent circuit at the different conditions at $900^{\circ} \mathrm{C}$, Note:

$\chi^{2}$ reflects the deviation of the experimental data and the fitting data

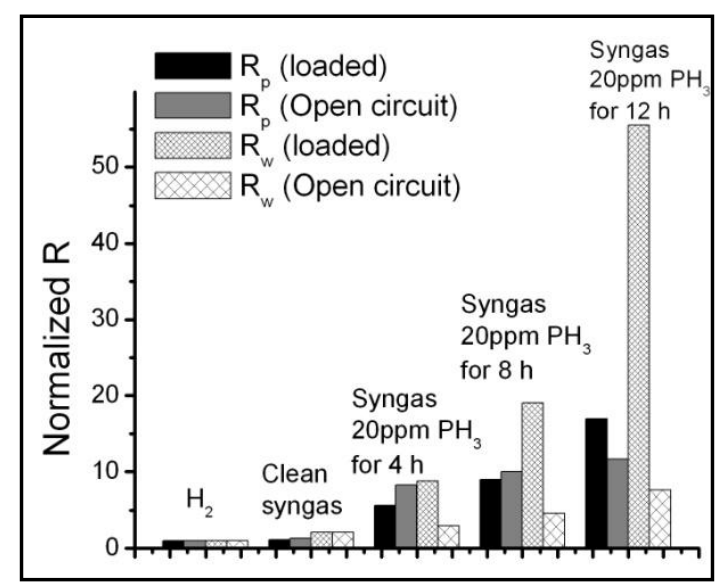

Figure 3.7 Charge transfer resistance $\left(R_{p}\right)$ and diffusion resistance $\left(R_{w}\right)$ derived from the impedance spectra obtained at $900^{\circ} \mathrm{C}$

\subsubsection{Microstructural Analysis}

In order to elucidate the reason for the change in both the charge transfer resistance and the diffusion resistance in the impurities contained syngas, we have examined the microstructural evolution of the Ni-YSZ working electrode after exposure to the $\mathrm{PH}_{3}$-containing syngas. The CTR electrodes were not examined, because we focused attention on the electrode at which hydrogen and $\mathrm{CO}$ are oxidized in the SOFC. 
Figure 3.8 shows the SEM images of the working electrode of the half cell. The Ni-YSZ electrode shows a well defined matrix structure with many pores after exposure to the clean syngas (Figure.3.8 (a)). In contrast, after exposure to the syngas with $\mathrm{PH}_{3}$, the particles in the electrode were coarsened and the porosity was significantly reduced (Figure.3.8 (b)). At the DC bias of 0.7V, the scenario became worse (Fig.3.8 (c)). The round-shaped particles disappeared on the electrode surface while flat flake-like particles appeared. The porosity was reduced remarkably. In this case, the gas channels were blocked to a severe extent. Therefore, it is understandable that the impedance plot after 12 hours of exposure to the syngas with $\mathrm{PH}_{3}$ at a loading of $0.7 \mathrm{~V}$ shows a Warburg tail (Figure $3.5(\mathrm{~b})$ ). 

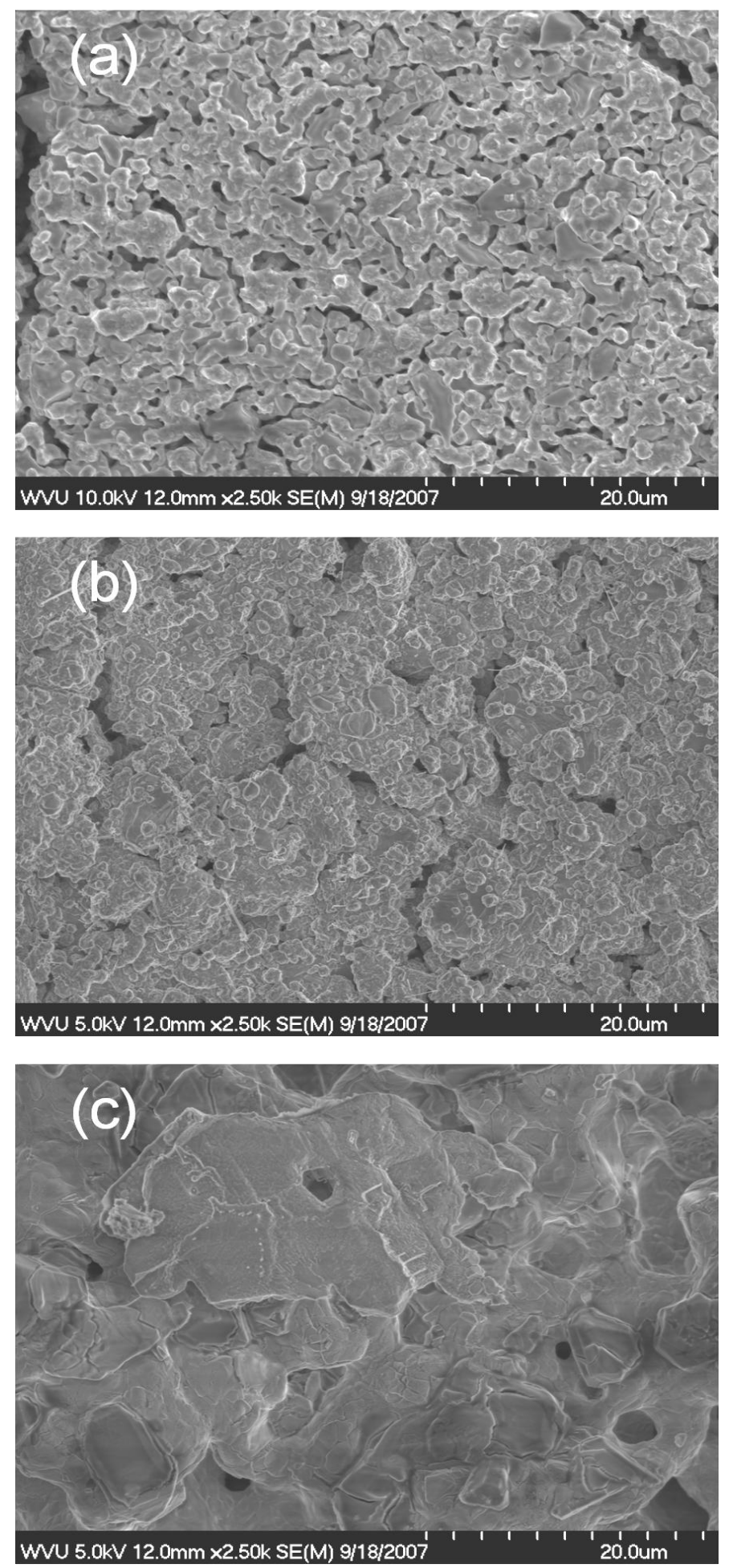

Figure 3.8 SEM images of the Ni-YSZ working electrode surface; (a) the electrode after exposure to the clean syngas (clean cell); (b) the electrode after exposure to the $\mathrm{PH}_{3^{-}}$ containing syngas at the open circuit (c) the electrode after exposure to the $\mathrm{PH}_{3^{-}}$ containing syngas at the applied DC bias of $0.7 \mathrm{~V}$ 
Figure 3.9 reveals the XRD patterns obtained from the Ni-YSZ working electrode. Metallic Ni and YSZ were the majority of the phases observed in the electrode after exposure to the clean syngas (Figure 3.9 (a)). A trace amount of $\mathrm{NiO}$ was found in this sample. The formation of $\mathrm{NiO}$ may be due to the exposure of the electrode to moisture during cooling. After exposure to the $\mathrm{PH}_{3}$-containing syngas at the open circuit, $\mathrm{Ni}_{3}\left(\mathrm{PO}_{4}\right)_{2}$ and $\mathrm{ZrP}_{2} \mathrm{O}_{7}$ were found in the electrode besides YSZ, Ni and NiO (Figure.3.9 (b)). For the loaded cell (Figure.3.9 (c)), metallic Ni completely disappeared and the amount of YSZ was reduced considerably. In this case, $\mathrm{Ni}_{3}\left(\mathrm{PO}_{4}\right)_{2}$ was the dominant phase, although a small amount of YSZ was present.

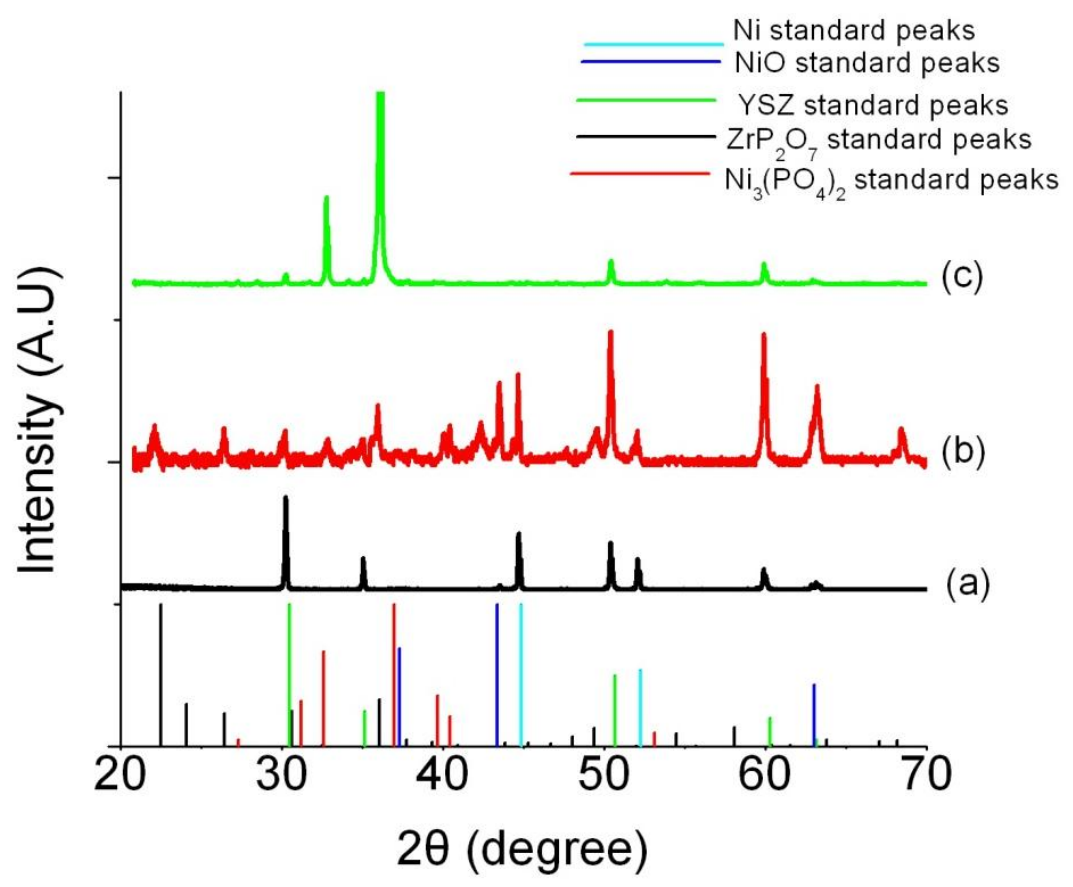

Figure 3.9 XRD patterns of the Ni-YSZ working electrode; (a) the electrode after exposure to the clean syngas (clean cell); (b) the electrode after exposure to the $\mathrm{PH}_{3}$ containing syngas at the open circuit (open circuit cell); (c) the electrode after exposure to the $\mathrm{PH}_{3}$-containing syngas at the applied DC bias of $0.7 \mathrm{~V}$ (loaded cell)

We used XPS to examine the outer surface layer of the working electrode, where the electrode surface is directly exposed to the $\mathrm{PH}_{3}$-containing syngas. Survey scans were performed to identify the chemical composition of the electrode surface. Detailed scans of specific core levels of individual elements were employed to examine the chemical 
structure of the electrode surface. Figure 3.10 shows the survey scan of the Ni-YSZ working electrodes. The P peak was absent in the XPS spectrum of the electrode after exposure to the clean syngas (clean cell). The $\mathrm{P} 2 \mathrm{p}$ peaks appeared in the spectrum of the electrode after exposure to the $\mathrm{PH}_{3}$-containing syngas at the open circuit, and the intensity of the $\mathrm{Zr} 3 \mathrm{~d}$ peaks decreased significantly. After exposure to the $\mathrm{PH}_{3}$-containing syngas at an applied DC bias of $0.7 \mathrm{~V}$, only the peaks associated with $\mathrm{P}, \mathrm{Ni}$ and $\mathrm{O}$ were found in the XPS spectrum. The Zr peaks completely disappeared. The disappearance of YSZ may be due to the fact that Ni diffused outward to the electrode surface under the applied electric field. This process would accelerate the reaction of $\mathrm{Ni}$ with the $\mathrm{PH}_{3}$ impurity, and thus buries the YSZ underneath the $\mathrm{Ni}_{3}\left(\mathrm{PO}_{4}\right)_{2}$ layer. 

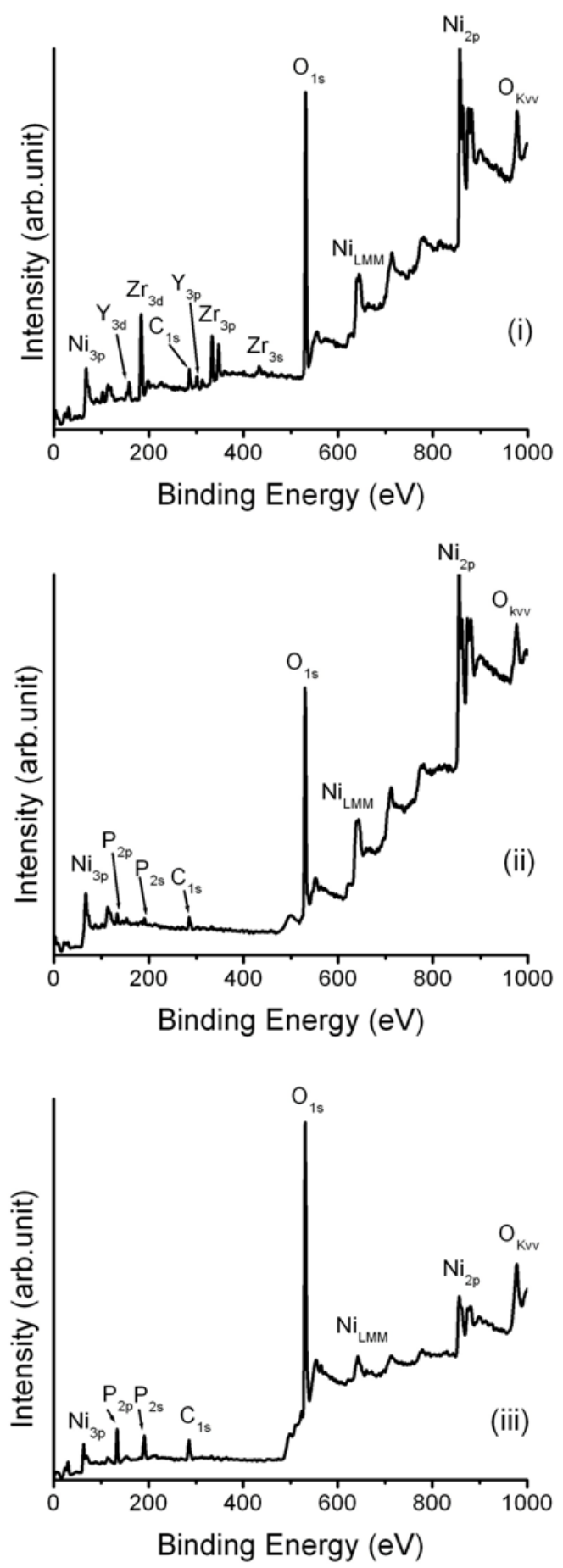

Figure 3.10 Survey scan of the XPS spectra obtained from the Ni-YSZ working electrode under different experimental conditions; (i) the electrode after exposure to the clean syngas (clean cell), (ii) the electrode after exposure to the $\mathrm{PH}_{3}$-containing syngas at the open circuit (open circuit cell), and (iii) the electrode after exposure to the $\mathrm{PH}_{3}$ containing syngas at the applied DC bias of $0.7 \mathrm{~V}$ (loaded cell) 
Figure 3.11(a), 11(b) and 11(c) reveal the detailed scans of the P 2p, Ni 2p, and Zr $3 \mathrm{~d}$ core levels, respectively. In the XPS spectra of the electrode after exposure to the clean syngas (clean cell), no P peak was found while the $\mathrm{Zr} 3 \mathrm{~d}$ peak was very strong. After exposure to the syngas contained $\mathrm{PH}_{3}$, the $\mathrm{P}$ peak became clearly visible. The height of the $\mathrm{Zr} 3 \mathrm{~d}$ peak was reduced considerably. At a loading of $0.7 \mathrm{~V}, \mathrm{Zr}$ was not detected. The P $2 p$ peak at $133 \mathrm{eV}$ is assigned to phosphates [11]. The Ni $2 \mathrm{p}_{3 / 2}$ peak at $854.1 \sim 854.7 \mathrm{eV}$ corresponds to nickel oxide [12]. The $\mathrm{Ni} 2 \mathrm{p}_{3 / 2}$ peak at $856.3 \mathrm{eV}$ is assigned to nickel phosphate [13]. The $\mathrm{Zr} 3 \mathrm{~d}$ doublet is centered at $182.5 \mathrm{eV}$ and 184.9 $\mathrm{eV}$, close to the reported values for YSZ [14]. The $\mathrm{Zr} 3 \mathrm{~d}_{5 / 2}$ peak at $183.0 \mathrm{eV}$ is attributed to zirconium phosphate [15]. 


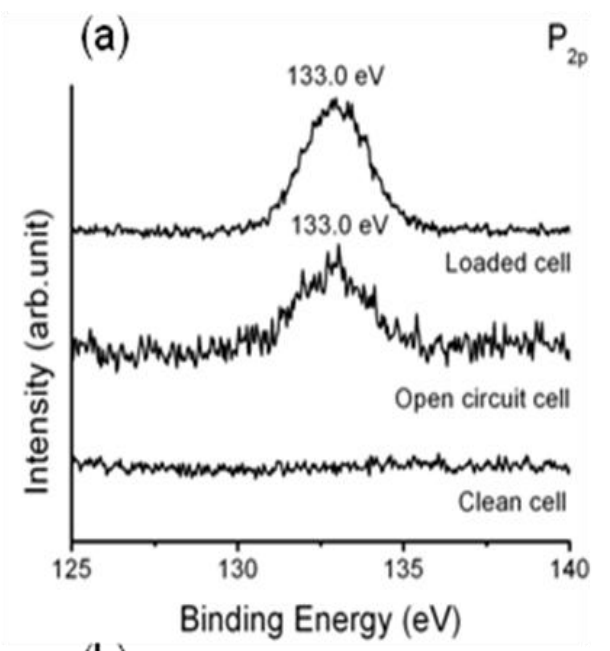

(b)

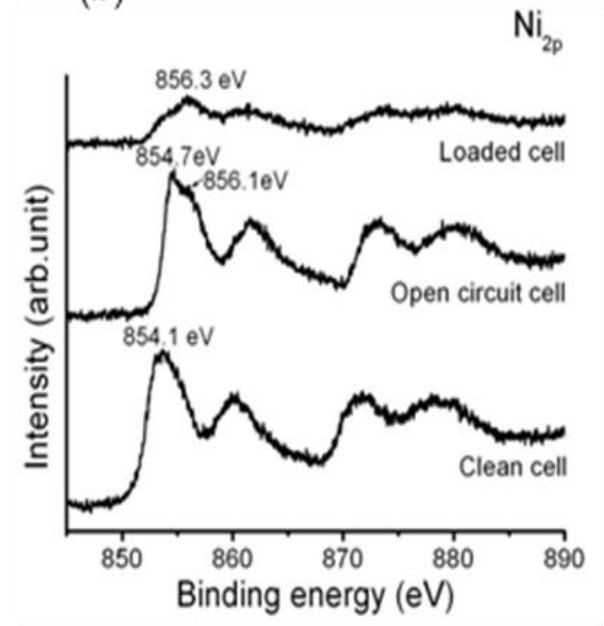

(c)

$$
\mathrm{Zr}_{3 \mathrm{~d}}
$$

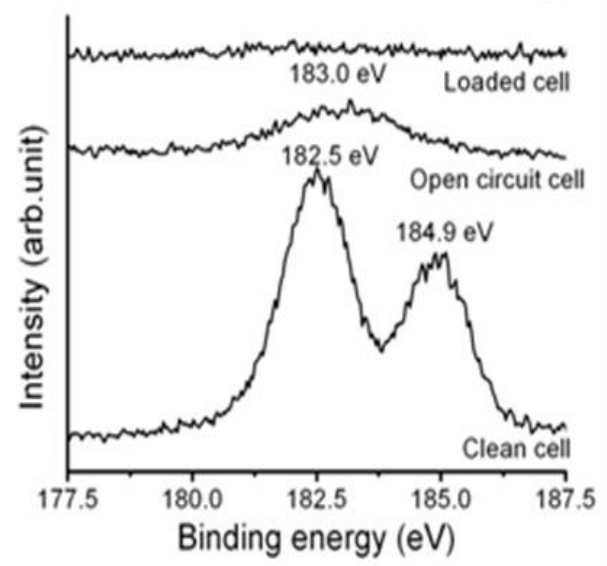

Figure 3.11 (a) XPS spectrum of the P 2p core level; (b) XPS spectrum of the Ni 2p core level; (c) XPS spectrum of the Zr 3d core level 
XPS and XRD measurements have clearly demonstrated that the incorporation of $\mathrm{P}$ into the electrode results in the formation of the secondary phases. The conversion of metallic Ni to nickel phosphate causes the electrode to lose the electrocatalytic activity toward oxidation of the fuel gas. The transformation of $\mathrm{YSZ}$ to $\mathrm{ZrP}_{2} \mathrm{O}_{7}$ inhibits the ability of electrode to transport oxygen ions in the electrode. Therefore, the charge transfer resistance increases with prolong of time during exposure to the $\mathrm{PH}_{3}$-containing syngas.

\subsection{Degradation of Ni-YSZ Anode in $\mathrm{PH}_{3}$ Contained Coal Syngas: Effect of the Temperature and $\mathrm{PH}_{3}$ Concentration:}

\subsubsection{Experimental Details}

Commercial electrolyte supported anode half cells are used in this research. The experiments are carried out in a tube furnace. Platinum paste was brushed on both of the half cell electrodes and then Ni mesh was glued on it. A Pt ring was painted at the edge of the electrolyte plate at the WKG side as the reference electrode (REF). The whole assembly was then put in a quartz tube; a thermal couple was placed right above the cell to monitor the temperature. Ag wires were in contact with each electrode to hook up with the test instruments, Ag paint was used at the wire junction to enhance the contact.

The half cell was placed at the center of a quartz tube inside a tube furnace. A thermocouple was placed adjacent to the half cell to monitor the temperature. The electrode was heated to $650^{\circ} \mathrm{C}$ at $1{ }^{\circ} \mathrm{C} / \mathrm{min}$ in $\mathrm{N}_{2}$ prior to testing, and then $\mathrm{H}_{2}$ was introduced till the cell temperature reached the experimental temperatures to reduce the $\mathrm{NiO}$ to be $\mathrm{Ni}$.

The fuel gas used in the experiments is $\mathrm{H}_{2}$ and simulating coal syngas as list in Table 3.2. $\mathrm{PH}_{3}$ impurity was introduced to the rig by using $\mathrm{PH}_{3} / \mathrm{N}_{2}$ gas mixture. The temperature range tested was from $750^{\circ} \mathrm{C}$ to $900^{\circ} \mathrm{C}$ with $50{ }^{\circ} \mathrm{C}$ interval. The impurity concentrations were set at $5 \mathrm{ppm}$ and $10 \mathrm{ppm}$, respectively. The duration of the impurity experiments is $84 \mathrm{hrs}$, with $12 \mathrm{hr} \mathrm{H}$, $24 \mathrm{hr}$ clean syngas and $48 \mathrm{hr}$ syngas plus $\mathrm{PH}_{3}$ impurity. After testing, $\mathrm{N}_{2}$ was applied and the temperature of the cells decreased to room temperature. Overall 8 samples were tested and analyzed. 
The electrochemical performances of the cells were investigated by interpretation the impedance data. All impedance spectrums were measured from $300 \mathrm{~K}$ to $0.1 \mathrm{HZ}$ using a Saloton SI 1260 impedance/grain-phase analyzer coupled with Solartron 1287 potentiostat, the amplitude is $10 \mathrm{mV}$, and the data are fitted using the commercial Zview and Cview software. The DC polarization curves were obtained by applied DC bias from $0 \mathrm{~V}$ to $0.5 \mathrm{~V}$ between the $\mathrm{REF}$ and the $\mathrm{WKG}$ with $10 \mathrm{mV} / \mathrm{s}$ rates. One set of electrochemistry data was recorded after $12 \mathrm{hr} \mathrm{H}_{2}$ exposure and two were recorded at each $12 \mathrm{hr}$ in clean syngas to verify the stability of the cells under clean fuel. After that, three sets of data were gained in $\mathrm{PH}_{3}$ contained syngas every $16 \mathrm{hr}$. The impedance spectra were fitted by the Zview ${ }^{\circledR}$ software, and the Tefel plots were fitted by Cview ${ }^{@}$ software.

The morphology of the Ni-YSZ anode was examined with a Hitachi S-4700 scanning electron microscope (SEM). The chemical status and chemical composition of the anode was characterized with a PHI Model 5000 X-ray photoelectron spectroscopy (XPS). XPS was performed with a monochromatic Al $\mathrm{K} \alpha$ radiation $(1486.6 \mathrm{eV})$ with an operating power of $25 \mathrm{~W}$.

\subsubsection{Results and Discussion:}

\subsubsection{Electrochemistry measurements}

Impedance spectra were taken at 750, 800, 850 and $900{ }^{\circ} \mathrm{C}$, respectively. Figure 3.12 shows the impedance spectra obtained from the half cell in the syngas containing 10 ppm $\mathrm{PH}_{3}$ at $800^{\circ} \mathrm{C}$. In the wet $\mathrm{H}_{2}$ gas, the impedance was stable and kept almost unchanged for 12 hours (Curve (a) in Figure 3.12). Then the fuel gas was switched from the wet $\mathrm{H}_{2}$ gas to the clean coal syngas. The arc was enlarged (Curve (b) in Figure 3.12) when the fuel was switched to the clean coal syngas, which was attributed to the dilution of the fuel, the slow $\mathrm{CO}$ diffusion rate (due to the large molecule weight), and to the high energy barrier for $\mathrm{CO}$ oxidation [16]. After the half cell was exposed to the clean syngas for 12 hours and 24 hours, impedance spectra were taken as shown in Curve (b) and (c) in Figure 3.12. The two curves were completely overlapped, which indicated no evident degradation at this stage. In contrast, after $10 \mathrm{ppm} \mathrm{PH}_{3}$ was introduced into the coal 
syngas, the impedance arc increased as increased exposure time from 12 hours to 48 hours (Curve (d), (e) and (f) in Figure 3.12). This indicated that the total resistance of the electrodes consisting of the polarization resistances and the mass transfer resistances increased. After $48 \mathrm{~h}$ of exposure, a long tail appeared in the Nyquist plot of the impedance spectrum. This again suggests that mass transport limitation was dominant at this stage.

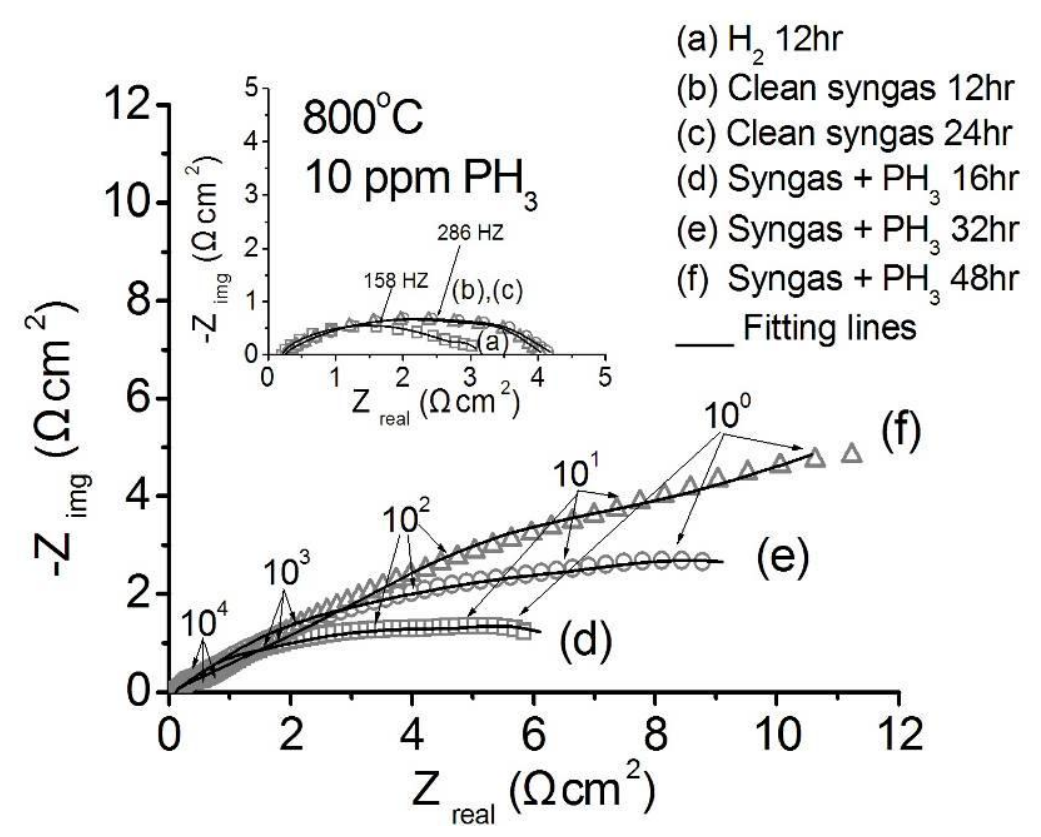

Figure 3.12 Nyquist plots of the impedance spectra taken from the half cell in the syngas containing $10 \mathrm{ppm} \mathrm{PH}_{3}$ at $800{ }^{\circ} \mathrm{C}$

Equivalent circuit model was used to fit the impedance plots as shown in Figure 3.6. $R_{p}$ and $R_{w}$ were plotted as a function of the temperature (Figure 3.13). In order to compare the data collected from different samples and testing conditions, all the resistance values were normalized against the values obtained in wet $\mathrm{H}_{2}$ gas. At a certain $\mathrm{PH}_{3}$ concentration, both $R_{p}$ and $R_{w}$ increased with the testing temperature. It is worth noting that $R_{e}$ didn't show any significant change with time, which indicates no evident degradation of the current collector was detected. At a certain temperature, higher $\mathrm{PH}_{3}$ concentration exacerbated the degradation of the fuel cell. After $48 \mathrm{~h}$ of exposure $\mathrm{PH}_{3}$ at 
$900{ }^{\circ} \mathrm{C}, R_{w}$ became significant. It can be seen that the impurity had more significant effect on $R_{w}$ than $R_{p}$.
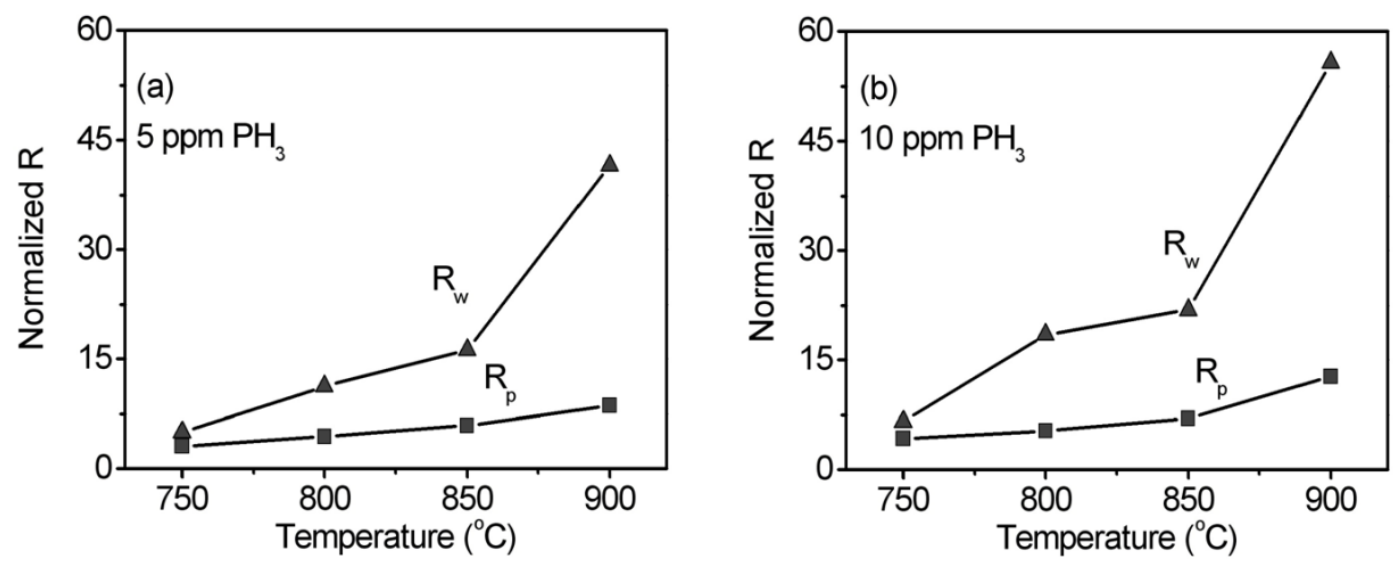

Figure 3.13 Normalized charge transfer resistance $\left(R_{p}\right)$ and mass transfer resistance $\left(R_{w}\right)$ as function of the temperature after $48 \mathrm{~h}$ of impurity exposure; (a) in $5 \mathrm{ppm}^{\mathrm{PH}_{3}}$ and (b)

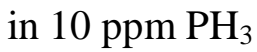

Besides AC impedance spectra, DC polarization curves were also recorded. Figure.3.14 shows the Tafel plots $(\log i$ versus $E)$. It is well known that the ButlerVolmer equation, which is applicable to an activation-controlled process, can be written as

$$
i=i_{o} \exp \left(\frac{B_{a} \eta_{a} F}{R T}\right)-i_{o} \exp \left(\frac{-B_{c} \eta_{a} F}{R T}\right)
$$

Where $i_{o}$ is the exchange current density related to the balanced forward and reverse electrode rates at equilibrium condition. $B_{a}$ and $B_{c}$ are the symmetrical coefficients. $\eta_{a}$ is the activation polarization. $R, T$, and $F$ are the gas constant, the temperature and the Faraday constant, respectively. Note that Tafel plots are valid only if the current is under kinetic control not mass transfer control. In the present work, mass diffusion plays a role in the electrode reaction during exposure to the $\mathrm{PH}_{3}$ impurity. Therefore, the polarization curve is called an apparent Tafel plot here. Correspondingly, an apparent exchange current $\left(i_{o}\right)$ is used. The apparent exchange current is not a true kinetic parameter, but its trend is useful to track the degradation of the anode.

At the high potential region of the Tafel plot, the equation can be simplified as 


$$
\log i=\log i_{0}+\frac{B_{a} \eta_{a} F}{R T}
$$

By extending the Tafel plot to zero potential, the $i_{o}$ value can be obtained [17]. Typical potential region in the present fitting process is between $0.3 \mathrm{~V}$ to $0.5 \mathrm{~V}$ by adjusting the cursors in the $\mathrm{Cview}^{\circledR}$ software. It should be noted that the applied DC bias was directly used in the calculation without calibrating to give an apparent exchange current. On the other hand, the exchange current density can be expressed as

$$
i_{0}=\frac{R T}{n F R_{p}}
$$

where $n$ is the total number of electrons transferred in the electrochemical reactions. Since the fuel gas used is $\mathrm{H}_{2}$ and $\mathrm{CO}$, two electrons were transferred for each of these molecules to be oxidized. Hence $n$ is set to be 2 here. Such a relationship allows one to calculate the $i_{o}$ value from the impedance spectra as $i_{o}$ yields from the estimated $R_{p}$ in the equivalent circuit model of impedance spectroscopy. The $i_{o}$ value derived from the Tafel plot was compared with that from the impedance spectra in order to evaluate the model as well as to monitor the degradation trend of the fuel cells. An example of such fitting is shown in Figure 3.15 where the Tafel plot was measured at $900{ }^{\circ} \mathrm{C}$ in $\mathrm{H}_{2}$. The calculated $i_{o}$ value was $\sim 33.0 \mathrm{~mA} \mathrm{~cm}$, which was compared to the result derived from the AC

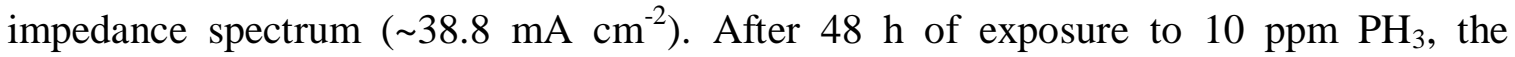
calculated $i_{o}$ was 3.0 and $2.4 \mathrm{~mA} \mathrm{~cm}^{-2}$ from the Tafel plot and the AC impedance spectroscopy, respectively.

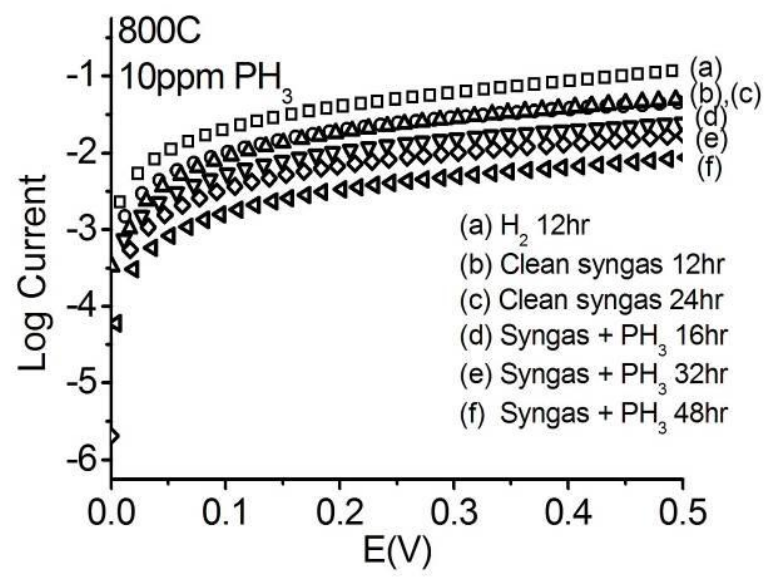

Figure 3.14 Tafel plots of the Ni-YSZ electrode $\left(800{ }^{\circ} \mathrm{C}, 10 \mathrm{ppm}^{\mathrm{PH}_{3}}\right)$ 


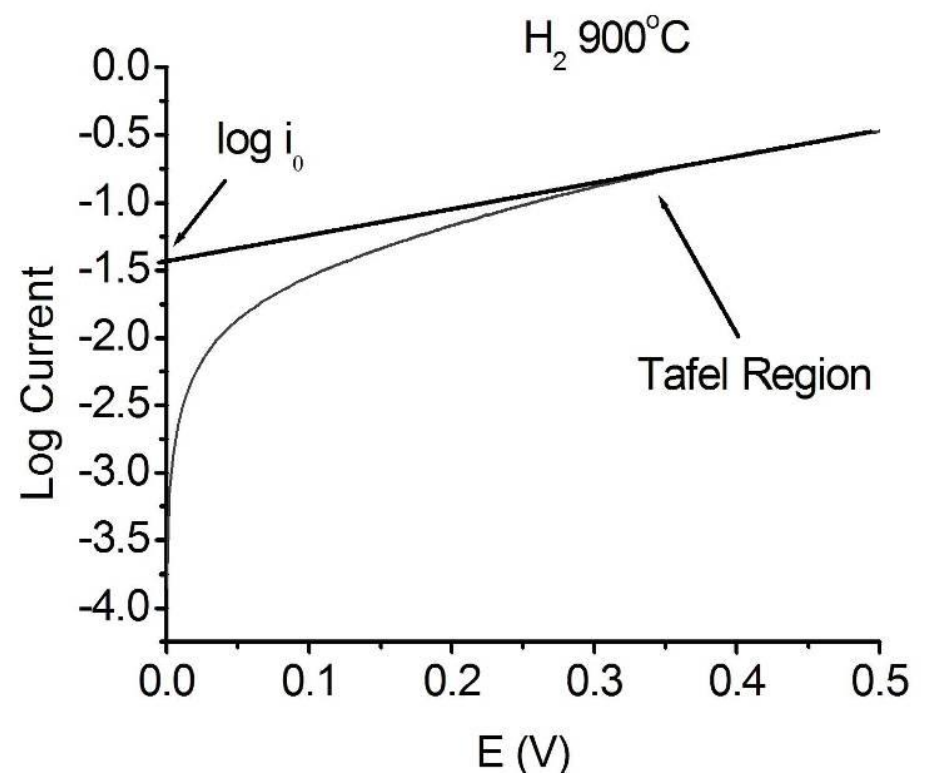

Figure 3.15 Illustration of the Tafel fitting

Based on electrochemical measurement, the electrocatalytic activity of the anode was considerably reduced by poisoning of the $\mathrm{P}$ impurity. Both the charge transfer resistance and the mass diffusion resistance dramatically increased after exposure to trace $\mathrm{PH}_{3}$. An increase in either the $\mathrm{PH}_{3}$ concentration or the temperature accelerated the poisoning effect.

\subsubsection{Microstructure Analysis}

In order to clarify the degradation mechanism of the electrochemical performance of the anode at different temperatures and $\mathrm{PH}_{3}$ concentrations, SEM and XPS were used to examine the evolution of chemical composition and the microstructure of the anode. Figurer 3.16 shows the SEM images of the Ni/YSZ electrodes. After $24 \mathrm{~h}$ of exposure to the clean syngas, the anode still kept the porous structure with the particle size 2 to $5 \mu \mathrm{m}$ (Figure 3.16 (a)). In contrast, the porosity was significantly reduced after $48 \mathrm{~h}$ of

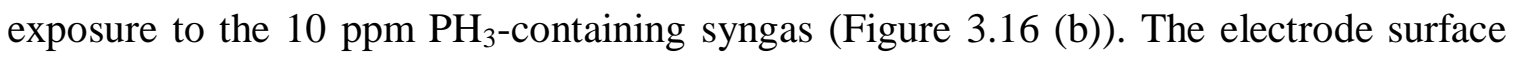
was composed of flat flakes with the presence of cracks between them. Such morphology retarded the gas diffusion into the electrode to a severe extent. Cross section SEM images in Figure 3.16 (c) and (d) also confirmed the degradation of the porous electrode structure. 
Keeping this in mind, it is not surprising that the Nyquist plot of impedance showed diffusion-controlled characteristics at the low frequencies range in Figure 3.12.
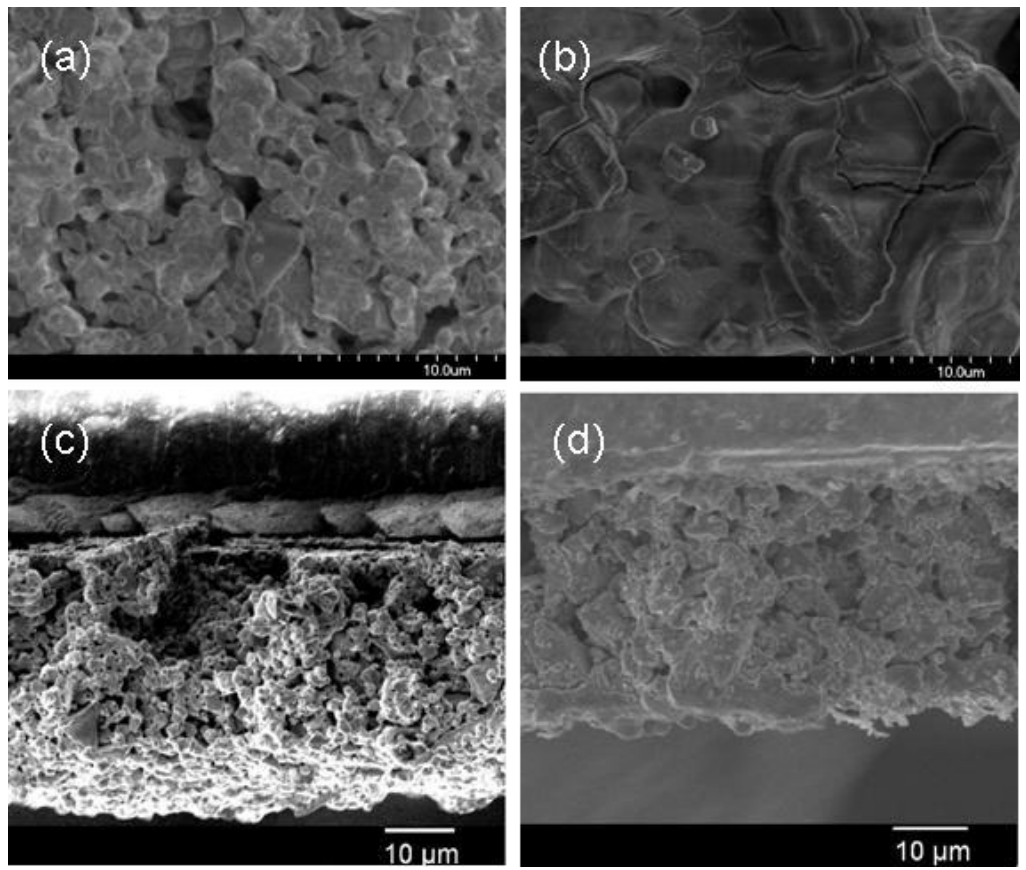

Figure 3.16 SEM images of the Ni/YSZ electrode (a) surface morphology after $24 \mathrm{~h}$ of exposure to the clean syngas at $900^{\circ} \mathrm{C}$, (b) surface morphology after $48 \mathrm{~h}$ of exposure to

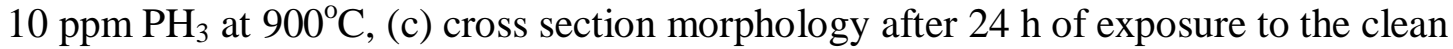
syngas at $900^{\circ} \mathrm{C}$ and (d) cross section morphology after $48 \mathrm{~h}$ of exposure to $10 \mathrm{ppm} \mathrm{PH}_{3}$ at $900^{\circ} \mathrm{C}$

Figure 3.17 (a) and 3.17(b) show the XPS spectra of the P 2p core level that were obtained from the anode at different temperatures after $48 \mathrm{~h}$ of exposure to $5 \mathrm{ppm}$ and 10 ppm, respectively. Before exposure, no phosphorous was detected in the Ni/YSZ anode. After exposure, phosphorous was found in all the anode samples. The relative intensity of the $\mathrm{P} 2 \mathrm{p}$ peak increased with increase in the temperature. The $\mathrm{P} 2 \mathrm{p}$ peak exhibited a binding energy at $133.0 \mathrm{eV}$, which corresponded to phosphate [10]. The formation of phosphates was also confirmed by the XRD analysis [18]. The SIMS measurement in Ref. [18] has confirmed a series of phosphate-associated ion clusters such as $\mathrm{PO}_{3}{ }^{-}$and $\mathrm{PO}_{2}{ }^{-}$over the cross section of the Ni/YSZ anode after operation in the $\mathrm{PH}_{3}$-containing syngas, which indicated the formation of phosphates. 
The Ni $2 \mathrm{p}_{3 / 2}$ peak at around $856.3 \mathrm{eV}$ in Figure.3.17(c) is attributed to phosphate [13]. The $\mathrm{Ni} 2 \mathrm{p}_{3 / 2}$ peak at around $854.7 \mathrm{eV}$ is ascribed to $\mathrm{NiO}$ [12]. It is not surprising that $\mathrm{NiO}$ was present in the anode after it was cooled down, because moisture was still present. In order to estimate the chemical composition evolution of the electrode surface, the XPS peak intensity ratio of the P $2 \mathrm{p}$ peak to the Ni $2 \mathrm{p}$ peak, $I_{p / N i}$, is plotted as a function of the testing temperature (Figure 3.18). The $I_{p / N i}$ value increased with increase in the testing temperature. Higher $\mathrm{PH}_{3}$ concentration always gave a higher $I_{p / N i}$ value at a certain testing temperatures. At $900^{\circ} \mathrm{C}$, increasing the $\mathrm{PH}_{3}$ concentration from $5 \mathrm{ppm}$ to $10 \mathrm{ppm}$ brought the $I_{p / N i}$ value from 0.07 to 0.22 .
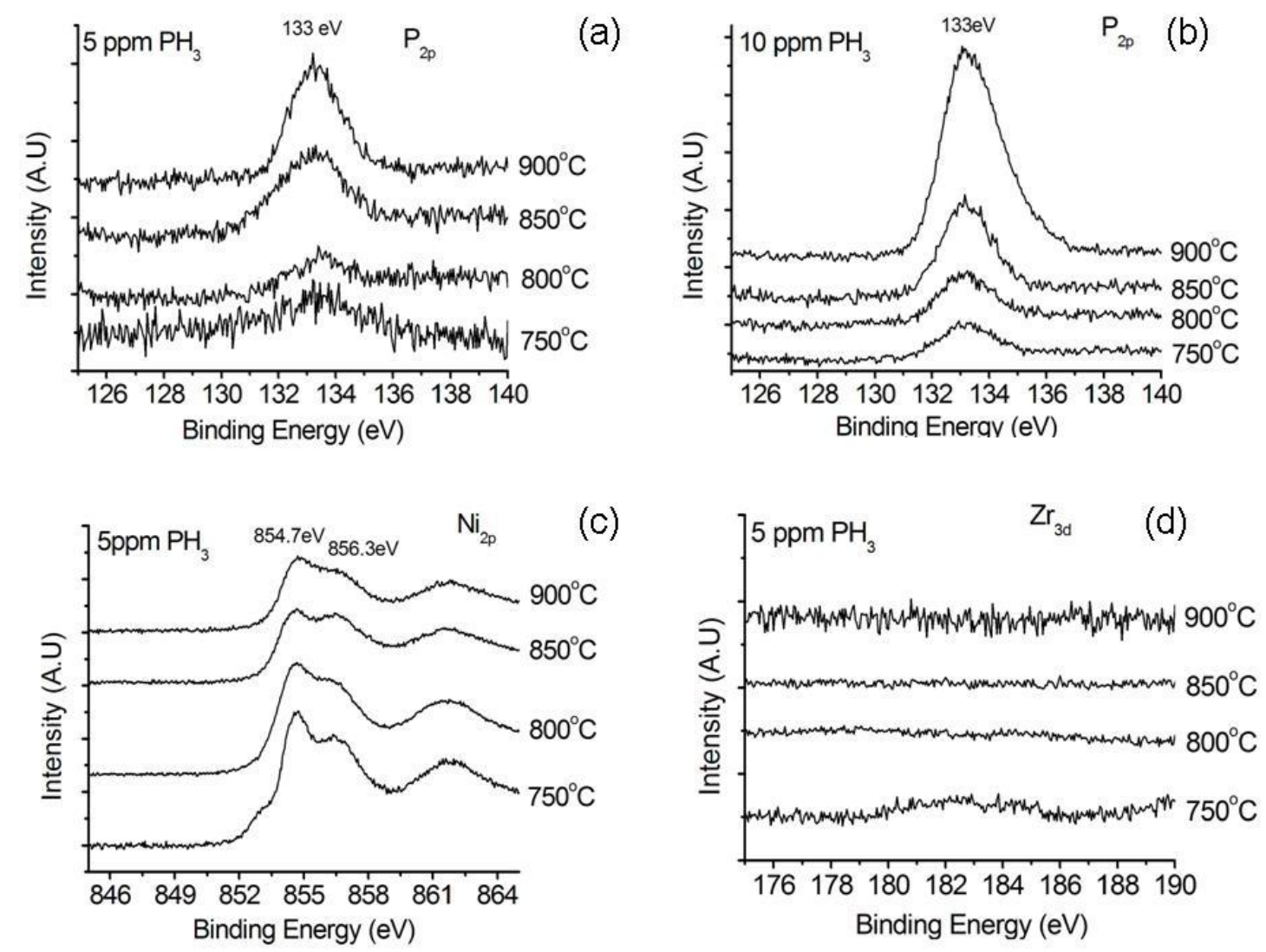

Figure 3.17 XPS spectra of (a) P 2p core level after exposure to $5 \mathrm{ppm} \mathrm{PH}_{3}$, (b) P $2 \mathrm{p}$ core

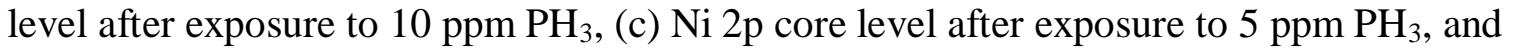
(d) $\mathrm{Zr} 3 \mathrm{~d}$ core level after exposure to $5 \mathrm{ppm} \mathrm{PH}_{3}$

It is worth noting that only a small $\mathrm{Zr} 3 \mathrm{~d}$ peak was detected in the anode after exposure at $750{ }^{\circ} \mathrm{C}$ (Figure. 3.17(d)). At higher temperature, the $\mathrm{Zr} 3 \mathrm{~d}$ peak almost 
disappeared. For the Ni/YSZ anode, the peak intensity ratio of $\mathrm{Zr} 3 \mathrm{~d}$ to $\mathrm{Ni} 2 \mathrm{p}$ was around 3 before exposure. After exposure in $5 \mathrm{ppm} \mathrm{PH}_{3}$ at $750^{\circ} \mathrm{C}$, it decreased to 0.05 . Higher $\mathrm{PH}_{3}$ concentration $(10 \mathrm{ppm})$ further reduced its value to 0.02 . This suggests that the attack of phosphorous species to the Ni/YSZ anode caused the depletion of $\mathrm{Zr}$ on the surface of the anode. This is consistent with the results reported in the references [18].

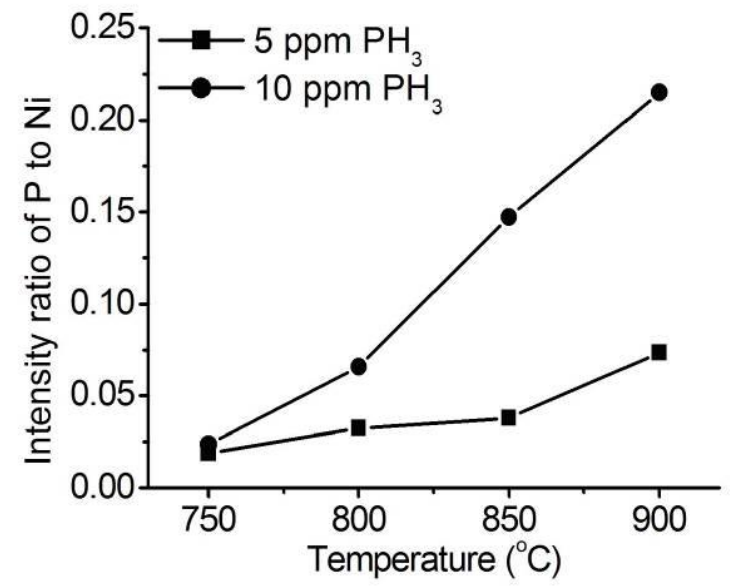

Figure 3.18 The XPS peak intensity ratio of $\mathrm{P} 2 \mathrm{p}$ to Ni $2 p$

Based on the gas phase equilibrium calculations and the XPS data, the reaction pathway of the phosphorous impurity with the nickel in the anode is proposed as follows

$$
\begin{gathered}
2 \mathrm{PH}_{3}(\mathrm{~g})+3 \mathrm{H}_{2} \mathrm{O}(\mathrm{g})=\mathrm{P}_{2} \mathrm{O}_{3}(\mathrm{~g})+6 \mathrm{H}_{2}(\mathrm{~g}) \\
\mathrm{P}_{2} \mathrm{O}_{3}(\mathrm{~g})+3 \mathrm{Ni}(\mathrm{s})+5 \mathrm{H}_{2} \mathrm{O}(\mathrm{g})=\mathrm{Ni}_{3}\left(\mathrm{PO}_{4}\right)_{2}(\mathrm{~s})+5 \mathrm{H}_{2}(\mathrm{~g})
\end{gathered}
$$

In the present work, nickel phosphate is found instead of nickel phosphide. This is mainly due to the presence of water in the syngas, which leads to the conversion of $\mathrm{PH}_{3}$ to $\mathrm{P}_{2} \mathrm{O}_{3}$. It has been reported that nickel phosphide is unstable in ambient air and consequently nickel phosphide would be oxidized to phosphate [19]. Our result is in disagreement with the previous report [20] in which Nickel phosphide was claimed. Several factors need to be considered to explain this difference. Based on Gou et al [21], the dominant P-based secondary phase was found to be nickel phosphate such as $\mathrm{Ni}\left(\mathrm{PO}_{3}\right)_{2}$, at the active $\mathrm{Ni} / \mathrm{YSZ}$ interface especially in the presence of steam using anode supported cells. Ni phosphate appeared under the current collector mesh when $\mathrm{Ni}_{3} \mathrm{P}$ appeared at the uncovered area.

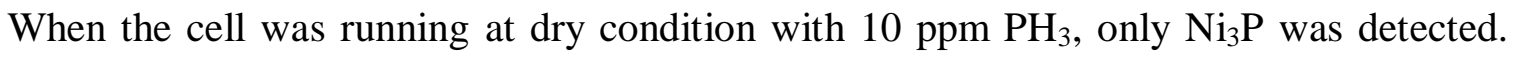
Therefore it is obvious that the cell operation history as well as the fuel gas have 
significant influence on the secondary phase formation. In my experiment, thin electrode was used with the thickness of $\sim 30-50 \mu \mathrm{m}$. The $\mathrm{H}_{2} \mathrm{O}$ gradient from the gas phase to the active layer is supposed to be smaller compared with thick anode used in PNNL. Nickel phosphate formed on the combining effect of $\mathrm{H}_{2} \mathrm{O}$ and the electrical current. The active layer of the thin electrode is more likely to convert to Nickel phosphate at the similar test conditions. Based on the thermodynamics calculation of Yokokawa et al [22], Ni phosphate such as $\mathrm{Ni}_{2} \mathrm{P}_{2} \mathrm{O}_{7}$ and $\mathrm{Ni}_{3}\left(\mathrm{PO}_{4}\right)_{2}$ are favorable when the oxygen partial pressure is higher than $10^{-17} \mathrm{~atm}$ as shown in Figure 3.19. In the thin anode of the electrolyte supported cells, the oxygen ions flux from the counter electrode and the $\mathrm{H}_{2} \mathrm{O}$ produced from the electrochemical reactions could create a higher oxygen partial pressure at the interface of the electrode/electrolyte and therefore Ni phosphate was observed.

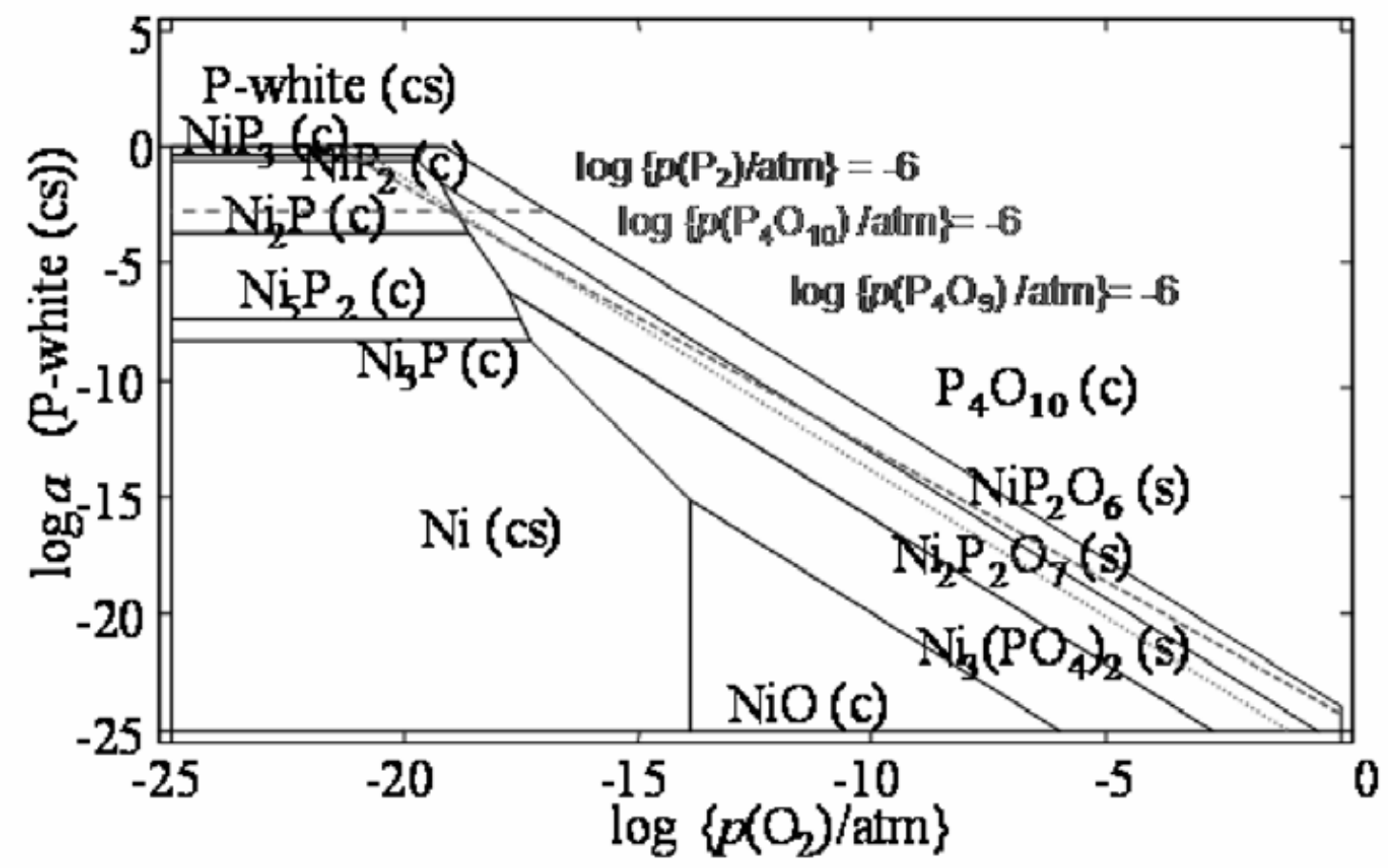

Figure 3.19. Two dimensional chemical potential diagram for the Ni-P-O system in a log $\{\mathrm{p}(\mathrm{O} 2) / \mathrm{atm}\}$ vs. $\log \mathrm{a}(\mathrm{P})$ plot at $1073 \mathrm{~K}$ [22]

The formation of the Ni phosphate instead of Ni phosphide could accelerate the degradation rate of the Ni-YSZ anode in $\mathrm{PH}_{3}$ containing syngas. As shown in Guo et al [21], when the cell running at $3 \%$ steam wet $\mathrm{H}_{2}$ condition and $\mathrm{Ni}_{3} \mathrm{P}$ was identified as the secondary phase, no degradation was observed. However when $26 \%$ steam was added 
into the fuel gas and $\mathrm{Ni}\left(\mathrm{PO}_{3}\right)_{2}$ was identified in ex-situ characterization, a $0.54 \mathrm{~mW} / \mathrm{hr}$ degradation was observed.

It should be noted that in the above mentioned degradation mechanism, $\mathrm{H}_{2} \mathrm{O}$ plays an important role as the reaction of $\mathrm{PH}_{3}$ to $\mathrm{P}_{2} \mathrm{O}_{3}$ become feasible when $\mathrm{H}_{2} \mathrm{O}$ is presented. It would be great interesting to investigate the anode operated in dry syngas with the same level of impurities. However, it would be difficult because the dry syngas could cause severely carbon deposition on the anode and such process can quickly cause anode degradation.

The incorporation of phosphorous into the electrode reduces the porosity in the Ni/YSZ anode (Figure 3.16), which retards the transport of the fuel gas into the triple phase boundary. The formation of nickel phosphate leads to the loss of catalytic activity of the anode. This also considerably lowers the conductivity of the anode. Therefore, both the charge transfer resistance and the diffusion resistance of the anode increase upon exposure to $\mathrm{PH}_{3}$. Higher $\mathrm{PH}_{3}$ content builds higher concentration gradient, which promotes the transport of the $\mathrm{P}$ species into the electrode. Higher temperatures favor overcoming the energy barrier for the formation of the secondary phase. Therefore, degradation is exacerbated by increase in the temperature or/and the impurity concentration.

\subsection{Conclusions:}

Gas equilibrium calculations show that $\mathrm{PH}_{3}$ is mainly converted to $\mathrm{P}_{2} \mathrm{O}_{3}$ after $\mathrm{PH}_{3}$ is introduced to the coal syngas at $750{ }^{\circ} \mathrm{C}-900{ }^{\circ} \mathrm{C} . \mathrm{P}_{2} \mathrm{O}_{3}$ reacts with nickel to form nickel

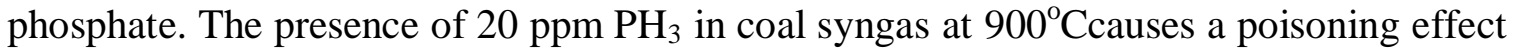
on the Ni-YSZ electrode. An equivalent circuit model is proposed to interpret the impedance data obtained from the Ni-YSZ/YSZ/Ni-YSZ half cell. Both the charge transfer resistance and the diffusion resistance of the Ni-YSZ electrode dramatically increase with time during exposure to the $\mathrm{PH}_{3}$-containing syngas. The diffusion resistance increases faster than the charge transfer resistance. The application of an electric field appears to accelerate the degradation of the Ni-YSZ electrode. During exposure to the syngas with $\mathrm{PH}_{3}$, phosphine reacts with $\mathrm{Ni}$ and $\mathrm{Zr}$ to form phosphates in the Ni-YSZ electrode, which suppresses the electrocatlytic activity of the electrode. The 
incorporation of phosphorus into the electrode and the subsequent formation of the secondary phases cause the blockage of the gas diffusion channels and the loss of the charge transport pathway. The effects of phosphorous poisoning tend to deteriorate at higher temperature and/or higher $\mathrm{PH}_{3}$ concentration from $750^{\circ} \mathrm{C}$ to $900^{\circ} \mathrm{C}$. 


\section{References for Chapter 3:}

[1] Can be found under http://www.cantera.org

[2] W. R. Smith and R. W. Missen, Chemical Reaction Equilibrium Analysis: Theory and Algorithms, 1982, Wiley Inter Science

[3] M. Binnewies and E. Milke, Thermochemical Data of Elements and Compounds, $2^{\text {nd }}$

Ed. 2002, Wiley Inter Science

[4] G. N. Krishnan, Technical progress report 1, SRI International, Morgantown, 2006

[5] M. Zhi, F. N. Cayan, I. Celik, R. Gemmen, S. R. Pakalapati and N. Q. Wu, Fuel Cells, $10,2010,174-180$.

[6] S. B. Adler, J. Electrochem Soc., 149, 2002, 166.

[7] N. Q. Wu, Z. Chen, J. Xu, M. Chyu and S.X. Mao, Sens. Actuators B., 110, 2005, 48

[8] S. B. Alder, Solid State Ionics, 111, 1998, 125

[9] N. Robertson and J. N. Michaels, J. Electrochem. Soc., 138, 1991, 1494

[10] J. R. Macdoland and W. R. Kenan, Impedance Spectroscopy, Wiley, New York, 1987, pp 71-73.

[11] J. F. Moulder, W. F. Stickle, P. E. Sobol and K. D. Bomben, Handbook of X-ray photoelectron Spectroscopy, Eden Prairie, 1992, pp 59-60.

[12] J. F. Moulder, W. F. Stickle, P. E. Sobol and K. D. Bomben, Handbook of X-ray photoelectron Spectroscopy, Eden Prairie, 1992, pp 85-86.

[13] S. S. Park, S. J. Choe, D. H. Park, Korean J. Chem. Eng., 20, 2003, 256

[14] M. B. Pomfret, C. Stolz. B. Varughese and R.A. Walker, Anal. Chem., 77, 2005, 1791 
[15] E. T. Paparazzo, E.Severini, A. Jimenez-Lopez, P. Maireles-Torres, P. OliveraPastor, E. Rodriguez-Castellon and A. A. G. Tomlinson, J. Mater. Chem., 2, 1992, 1175

[16] E. H. Pacheco, M.D. Mann, P.N. Hutton, D. Singh and K. E. Martin, Inter. J. Hydrogen. Energy, 2005, 30, 1221

[17] P. G. Keech, D. E. Trifan and V. I. Birss, J. Electrochem. Soc., 2005, 152, A645

[18] M. J. Zhi, X. Q. Chen, H. Finklea, I. Celik and N. Q. Wu, J. Power Sources, $2008,183,485$

[19] O. A. Marina, L.R. Pederson, D.J. Edwards, C.W. Coyle, J. Templeton, M. Engelhard and Z. Zhu, Proceedings of the 8th Annual SECA Workshop 2007 San Antonio, TX

[20] J. F. Moulder, W. F. Stickle, P. E. Sobol and K. D.Bomben, Handbook of X-ray photoelectron Spectroscopy 1992, Eden Prairie, p84

[21] H. Guo, G. Iqbal and B. Kang, Int. J. Appl. Ceram. Technol in press

[22] H. Kishimoto, K. Yamaji, M. E. Brito, T. Horita and H. Yokokawa, Journal of Mining and Metallurgy, 44, 2008, 39 


\section{Chapter 4: Synthesis of Nanofibers for SOFC Cathode Application}

\subsection{Background:}

Utilization of 1-D nanomaterials such as nanowire, nanotubes, and nanorods in different applications has been widely studied recently, such as batteries [1], gas sensors [2] and solar cells [3]. The unique structure of these 1-D nanomaterials could offer several advantages compared with the traditional 0-D nanoparticles. For example, it has been reported the 1-D nanomaterials own increased surface vacancy density and specific surface area as well as charge transfer ability [4-5].

The basic microstructures requirements for a SOFC electrode as discussed in Chapter 2 include:

1. Porous structure, which favors gas diffusion. The porosity of the electrode will largely affect the performance of the fuel cell. As studied by Suzuki et al [6], the maximal power output of SOFC is proportional to the porosity of the anode. The porosity of 1-D nanostructures can be easily tuned from macro to micro scale, which has been realized in gas sensors.

2. Large gas/catalyst interface: The oxygen reduction reaction on SOFC cathode is a surface reaction which occurs at the gas/catalyst interface, increasing the volume/mass ratio is important for achieving maximum active reaction sites [7], especially for the MIEC cathode. 1-D nanostructures normally own high surface/volume ration, which makes them ideal as catalysts.

3. Continuous charge transfer pathway: In the cathode, oxygen ions and electrons need to be transferred all the way from the cathode/electrolyte interface to the cathode surface. Therefore, increase the conducted paths within the microstructure can enhance the charge mobility and reduce the overpotential. Especially in the LSM/YSZ cathode, the electron and the oxygen ion pass separately, it is then crucial to maintain the uninterrupted pathways for both charges. For the random distribution particles, the dead end of the disconnected region could prohibit the charge transfer and therefore limit the fully utilization of the electrode material. As recently reported in Ref [8] which was using ion beam to reconstruction the SOFC electrodes, it is found that about third of the TPB are not percolating and cannot be considered as the reaction active site. However, the 
long 1-D nanomaterials can be considered as a continued cable for charges moving through, therefore the effective TPB can be maximized.

Although it has been discussed the advantages of the using 1-D nanomaterials in SOFC electrodes, there are only few reports so far on this topic, due to several challenges:

\section{Scaled up synthesis}

For commercial SOFC fabrication, usually large amount of nanomaterials will be needed with reproducible quality. One of the available approaches is template derived method, which fills porous template such as AAO (Anodic Alumina Oxide) or polymer membrane with precursor, sintering to form the nanomaterials and finally removing the template. Bellino et al. synthesized LSC and LSCF nanotubes using this method and got reasonable polarization resistance of the cathode constructed by such materials [9]. However, such methods are complicated and costly. The product size is limited by the template, yet a tunable aspect ratio is difficult to achieve.

\section{Thermal stability}

The nanomaterials will be subjected to severe environments in SOFC cathode. Initially the cathode needs higher temperature $\left(>1000^{\circ} \mathrm{C}\right)$ sintering in order to form an intimate connection between the electrode and electrolyte. The operation temperature of the SOFC is usually around $800^{\circ} \mathrm{C}$, with several thousand hours running. Preventing the microstructure degradation is essential in order to maintain the cell stability. Belleno et al [10] found template derived LSCF nanotubes degraded into nanoparticles after $1000^{\circ} \mathrm{C}$ sintering, which again raised such issue. The bundled nanotubes structure will aggregate and sinter due to the large amount of the interconnection between individual nanotubes.

In order to overcome the above challenges, we proposed an electrospinning method to fabricate 1-D nanofibers for SOFC cathode application, which is a scaled up, template free and easy controllable method. The thermal stability of such materials was verified and the synthesis parameters were studied.

\subsection{Introduction of Electrospinning:}

Modern electrospinning was first developed in University of Akron in order to synthesize small diameter polymer nanofibers [11]. After which the method became popular for synthesizing inorganic nanofibers such as $\mathrm{TiO}_{2}$ [12], $\mathrm{ZrO}_{2}$ [13], $\mathrm{V}_{2} \mathrm{O}_{5}$ [14] etc. The basic principle of the electrospinning is injecting a viscous precursor droplet into an 
electrical field. The electrical force applied on the precursor droplet will overcome the its surface tension, therefore the droplet will stretch and above a critical electrical field strength a stream of liquid erupts from the droplet surface. Such a liquid jet will fly to the grounded collector, during this period the jet dries to solid. Therefore solid fibers can form on the collector. By adjusting the viscosity of the precursor, the electrical field density, the distance between the capillary and collection screen and the ambient parameters, the size of the fiber can be tuned [15]. Figure 4.1 shows the electrospinning process.

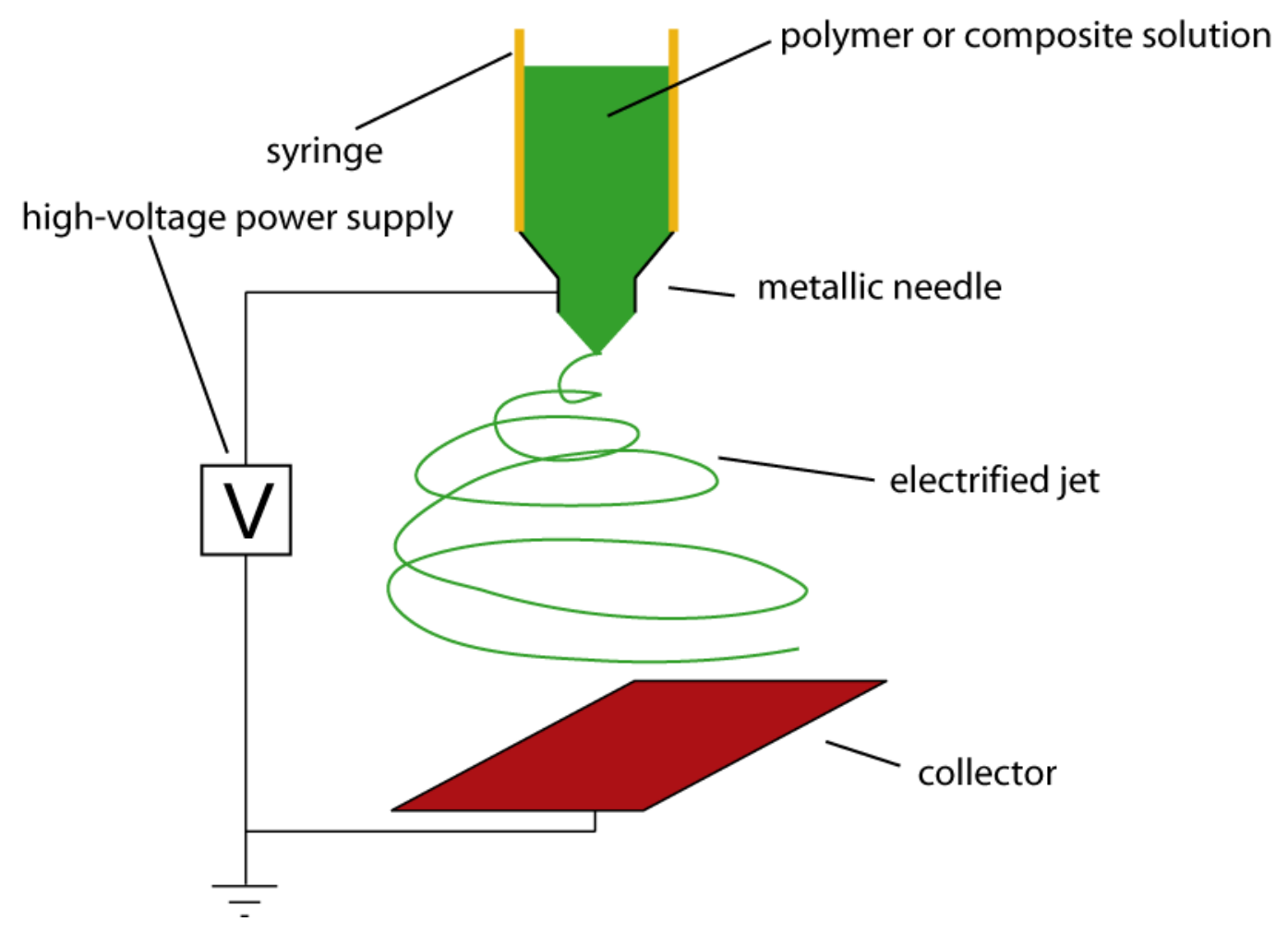

Figure 4.1 Schematic of the electrospinning process [16]

In order to prepare inorganic oxide nanofibers, a suitable polymer precursor should be first chosen. The polymer used in our lab is mainly Polyacrylonitrile (PAN, $\left(\mathrm{C}_{3} \mathrm{H}_{3} \mathrm{~N}\right)_{\mathrm{n}}$ ) and the solvent is $\mathrm{N}^{\prime} \mathrm{N}$-dimethylformamide (DMF, $\mathrm{C}_{3} \mathrm{H}_{7} \mathrm{NO}$ ), which are common adopted in preparing carbon nanofibers. The polymer precursor is then mixed with metal salt such as acetate or nitrate and subjects to electrospinning. The as spun fibers contain the mixture of the polymer and the metal salt. After that a high temperature 
heating process is used to burn off the polymer and crystallize the ceramic phase, therefore the desired inorganic oxide nanofibers are formed. A flowchart can be found in Figure 4.2.

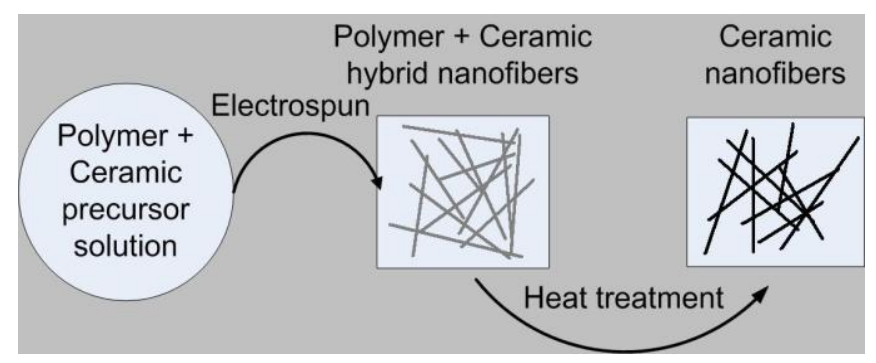

Figure 4.2 Flowchart of the nanofiber preparing process

Our research work is mainly focusing on prepare nanofibers with most common chemical composition, such as $\mathrm{La}_{0.8} \mathrm{Sr}_{0.2} \mathrm{MnO}_{3}$ (LSM), $\mathrm{Zr}_{0.92} \mathrm{Y}_{0.16} \mathrm{O}_{2}$ (YSZ), and $\mathrm{La}_{0.6} \mathrm{Sr}_{0.4} \mathrm{Co}_{0.2} \mathrm{Fe}_{0.8} \mathrm{O}_{3}$ (LSCF). In the following part we will discuss the experimental results for the above nanofiber samples.

\subsection{Nanofibers Preparation:}

\subsubsection{Equipment}

The spinning experiments were conducted in a home-made electrospun apparatus, which consists of a syringe pump (New Era), a high voltage power supply (Shimada), and a plastic glass box for shielding the whole system. The needles used are from Mcmaster, gauge 25 and are made of stainless steel. Aluminum foil was used as the fiber sample collector.

\subsubsection{Regent}

N'N-dimethylformamide (DMF) and Polyacrylonitrile (PAN) were used as the polymer and solvent. Zirconium hydroxide acetate $\left(\mathrm{Zr}\left(\mathrm{COOCH}_{3}\right)_{4-\mathrm{x}}(\mathrm{OH})_{\mathrm{x}}\right)$, and Yttrium nitrate hydrate $\left(\mathrm{Y}\left(\mathrm{NO}_{3}\right)_{3} \cdot 6 \mathrm{H}_{2} \mathrm{O}\right)$ were used for preparing YSZ nanofibers, The molecule weight of $\mathrm{Zr}\left(\mathrm{COOCH}_{3}\right)_{4-\mathrm{x}}(\mathrm{OH})_{\mathrm{x}}$ was determined by thermal decomposed method. A 
certain amount of the raw $\mathrm{Zr}\left(\mathrm{COOCH}_{3}\right)_{4-\mathrm{x}}(\mathrm{OH})_{\mathrm{x}}$ was heated to $1000^{\circ} \mathrm{C}$ and cooled down. The residue was confirmed to be $\mathrm{ZrO}_{2}$, therefore the molecule weight of $\mathrm{Zr}\left(\mathrm{COOCH}_{3}\right)_{4}$ ${ }_{\mathrm{x}}(\mathrm{OH})_{\mathrm{x}}$ can be calculated as 234 with $3 \%$ error. Lanthanum acetate hydrate $\left(\mathrm{La}\left(\mathrm{CH}_{3} \mathrm{COO}\right)_{3} \cdot 1.5 \mathrm{H}_{2} \mathrm{O}\right)$, Strontium acetate hydrate $\left(\mathrm{Sr}\left(\mathrm{CH}_{3} \mathrm{COO}\right)_{2} \cdot 0.5 \mathrm{H}_{2} \mathrm{O}\right)$ and Manganese acetate hydrate $\left(\mathrm{Mn}\left(\mathrm{CH}_{3} \mathrm{COO}\right)_{2} \cdot 4 \mathrm{H}_{2} \mathrm{O}\right)$ were used for preparing LSM nanofibers.

\subsubsection{Electrospinning Process}

In a typical experiment, 6\%wt PAN was added to DMF and stirred. A transparent solution was formed after this step. Metal salts were then added and the solution was further stirred to form the precursor. The precursor was loaded into a syringe. The syringe was mounted on the syringe pump and the dispensing rate was varied from 0.25 to 0.75 $\mathrm{ml} / \mathrm{hr}$. A $\sim 1-1.5 \mathrm{kV} / \mathrm{cm}$ electrical field was applied between the needle tip and the sample collector. The distance between the needle and the collector is fixed at $15 \mathrm{~cm}$. Visible white mat appeared on the collector after several minutes of spinning, and became thicker with the prolonged spun time. A typical experiment would last 8 hours. The as spun nanofiber mat was placed in hood to evaporate the residue solvent and moisture, then it was loaded into a ceramic combustion crucible and heated to high temperature in air atmosphere [17]. Several desired temperatures were used such as $600^{\circ} \mathrm{C}, 800^{\circ} \mathrm{C}$ and $1000^{\circ} \mathrm{C}$. Finally the fibers were cooled down at $5^{\circ} \mathrm{C} / \mathrm{min}$ to room temperature.

\subsubsection{Characterization Methods:}

The crystal structure of samples was characterized by X-ray powder diffraction (XRD, X'Pert Pro PW3040-Pro, Panalytical Inc) with $\mathrm{Cu}$ Ka radiation. The morphology was observed with a Hitachi S-4000 field-emission scanning electron microscope (FESEM). A thin piece of the nanofiber sheet was mounted on a carbon tape and a $\sim 10 \mathrm{~nm}$ thick gold was sputtered on the surface to enhance the conductivity.

\subsection{Results of YSZ Nanofibers}

Figure 4.3 shows the SEM image of an as spun YSZ nanofibers mat. It can be seen that long nanofibers were successfully formed using our electrospinning method. The size of the nanofibers is also uniform. The fibers can reach several centimeters in 
length and several hundred nanometers in diameter, which indicate a high length to diameter ratio.

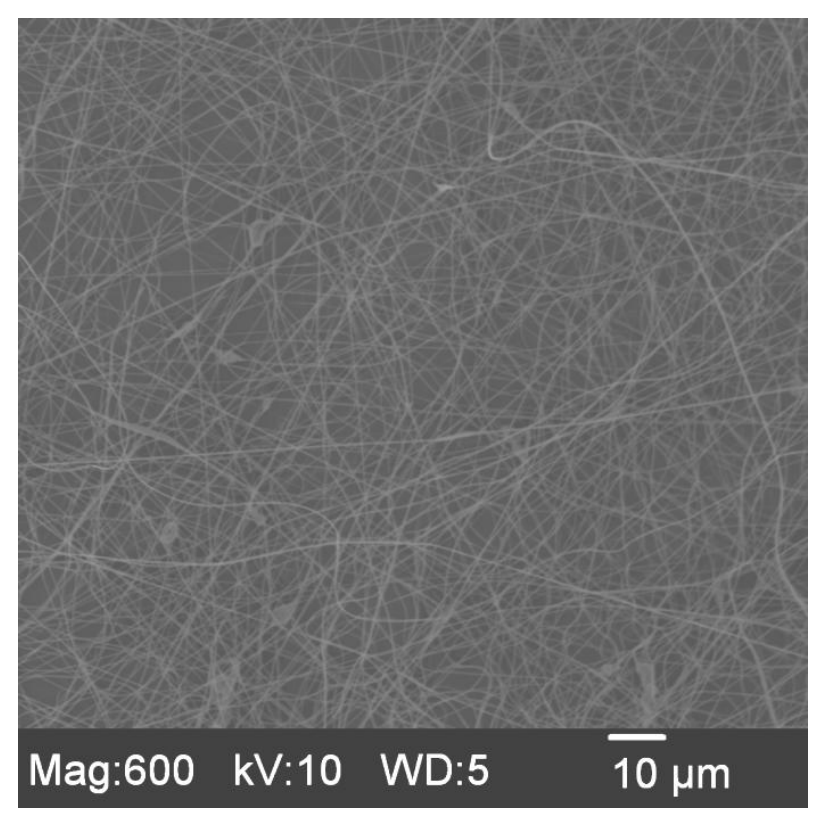

Figure 4.3 SEM image of the as spun YSZ nanofibers

The electrospinning is also a mass productive method to synthesis the nanomaterials, which is important for the fuel cell application. Unlike normal AAO or polymer membrane derived nanowires or nanotubes whose sizes are limited by the template size, electrospinning is a template free method [9], yet the process is more controllable and facile. Figure 4.4 is a picture taken after 10 minutes spinning, a thick and dense fiber mat has already covered a 4 inch diameter collector. A maximal production rate can reach to grams per day in our lab. 


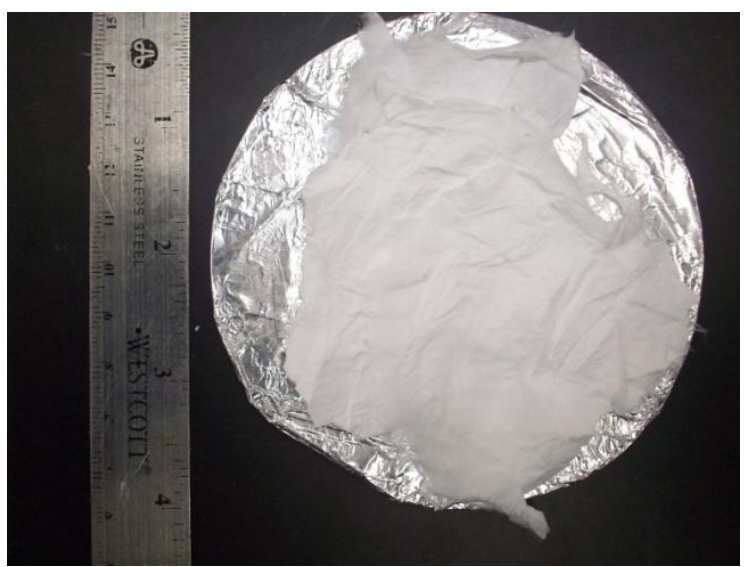

Figure 4.4 Picture of a 4 inch diameter sample collector after electrospinning experiment, the white sheet is the YSZ raw fiber mat

After the heat treatment step, the raw fibers started to turn into YSZ ceramic nanofibers. Such high temperature process burned out all the organic compounds as well crystallized the ceramic phase. The reaction can be written as:

$$
\begin{gathered}
\left(\mathrm{C}_{3} \mathrm{H}_{3} \mathrm{~N}\right)_{n}+\mathrm{O}_{2} \rightarrow \mathrm{C}+\mathrm{H}_{2} \mathrm{O}+\mathrm{NO}_{2},\left(\text { at } 280^{\circ} \mathrm{C}\right)[17] \\
\mathrm{C}+\mathrm{O}_{2} \rightarrow \mathrm{CO}_{2}\left(280^{\circ} \mathrm{C} \text { to } 600^{\circ} \mathrm{C}\right) \\
\left(\mathrm{Zr}\left(\mathrm{COOCH}_{3}\right)_{4-x}(\mathrm{OH})_{x)}+\mathrm{Y}\left(\mathrm{NO}_{3}\right)_{3} \cdot 6 \mathrm{H}_{2} \mathrm{O} \rightarrow \mathrm{Zr}_{0.92} \mathrm{Y}_{0.16} \mathrm{O}_{2}+\mathrm{CO}_{2}+\mathrm{H}_{2} \mathrm{O}\right.
\end{gathered}
$$

Typical morphology of the YSZ nanofibers obtained at $600^{\circ} \mathrm{C}$ can be found at Figure 4.5. It can be seen that the product mantains its fibrous structure after heating. Some long fibers are several tens of microns which indicates the structure integrity of the nanofibers.

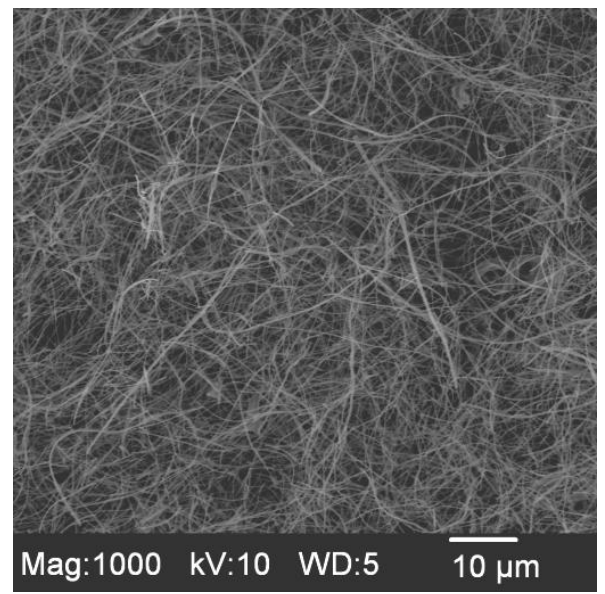

Figure 4.5 SEM image of the YSZ nanofibers obtained after $600^{\circ} \mathrm{C}$ heating 
The thermal stability of the YSZ nanofibers was also examined. As for SOFC cathode, a high temperature sintering process $\left(1000-1300^{\circ} \mathrm{C}\right)$ is necessary to form an intimate connection between the electrode and the electrolyte. Therefore, we heat treated the YSZ nanofibers derived at $600^{\circ} \mathrm{C}$ further at $1000^{\circ} \mathrm{C}$ for 3 hours with $1{ }^{\circ} \mathrm{C} / \mathrm{min}$ heating rate and scan the morphology. Figure 4.6 are the SEM images of the sample at different magnification. It can be found that the fibers structure was retained. Most fibers are still over $10 \mu \mathrm{m}$ in length. Figure 4.6 (c) reveals that the fiber's diameter is around $150 \mathrm{~nm}$ and one single fiber is consisted of multiple connected nanoparticles. Therefore, it can be conclude that the YSZ nanofibers can at least keep their porous and nano nature at the conventional SOFC cathode fabrication conditions.
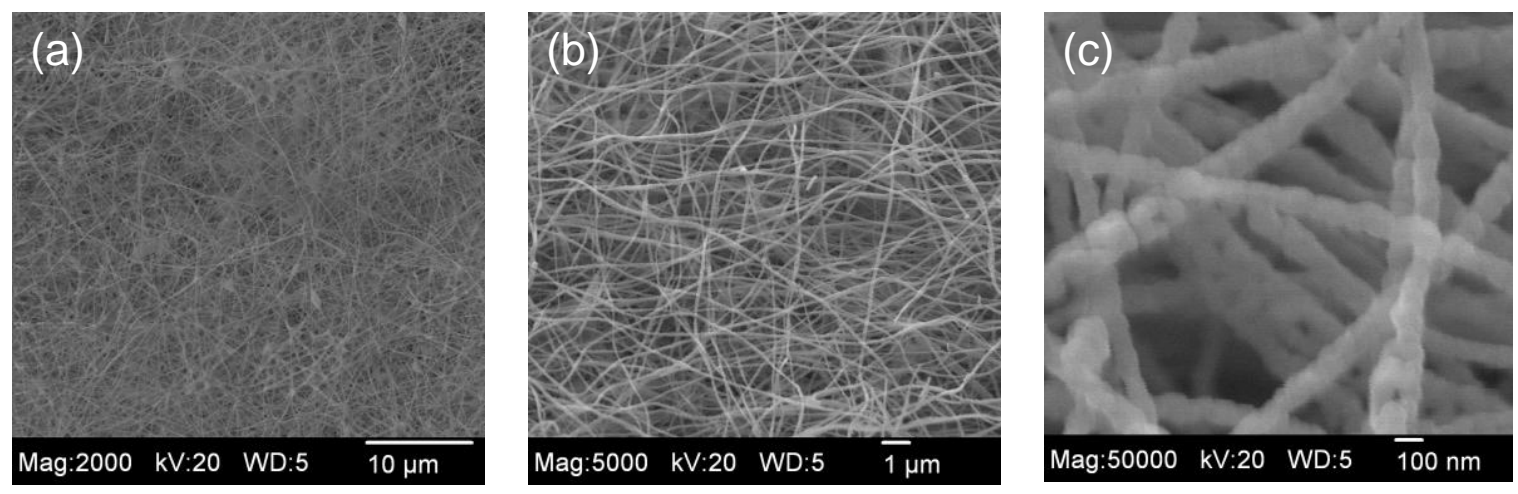

Figure 4.6 SEM image of the YSZ nanofibers after $1000^{\circ} \mathrm{C}$ heating for 3 hours, from (a) to (c) are low to high magnifications

The XRD result of the YSZ nanofibers obtained at different temperatures is shown in Figure 4.7. All of the peaks can be assigned to cubic $\mathrm{ZrO}_{2}$ phase without secondary phase, which indicates a successful doping of the $\mathrm{Y}$ into the $\mathrm{ZrO}_{2}$ lattice. It can also be seen that the full width at half maximum peak decreased with evaluated heat treatment temperatures, which reveals a grain growth process. Scherrer's equation was used to estimate the grain size in the nanofibers, which can be expressed as

$$
D_{p}=\frac{0.94 \lambda}{\beta_{1 / 2} \cos \theta}
$$


in which $D_{p}$ is the grain size, $\lambda$ is the $\mathrm{X}$-ray wave length $(0.154 \mathrm{~nm}), \beta_{\frac{1}{2}}$ is the full width at half maximum peak in degree, and $\theta$ is the diffraction angle of the peak position. The highest intensity peak (around $30^{\circ}$ in $2 \theta$ ) was used in the calculation. The grain sizes derived from the XRD data are $\sim 7 \mathrm{~nm}, 13 \mathrm{~nm}$ and $30 \mathrm{~nm}$ for the YSZ nanofibers obtained at 600,800 and $1000^{\circ} \mathrm{C}$, which indicates these nanofibers to be consisted of fine nano grains. Unlike normal nanoparticles which will severely sinter with larger grain, the large space within the nanofibers network prevents the mass diffusion for aggregation, so the grain can keep sub $100 \mathrm{~nm}$ size even at high temperature.

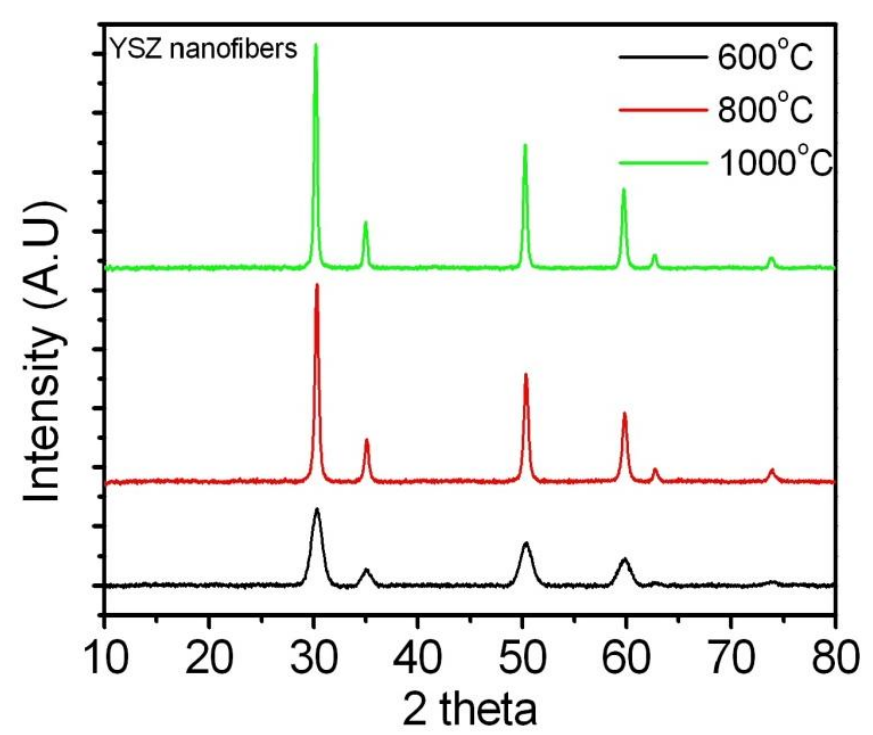

Figure 4.7 XRD pattern of the YSZ nanofibers obtained after different temperature heat treatment

Furthermore, based on literature $[17,18]$ and the XRD results, a hypothesis can be proposed to explain the nanofibers formation. After initial $280^{\circ} \mathrm{C}$ heating, PAN is decomposed to carbon, such carbonized process stablized the nanofiber morphology [17]. Higher temperature heating promoted the ceramic phase formation, which created small nano grains to assembly the nanofiber. Further heating caused grains growth, which can explain the increasing grain size. A diagram of the mechanism is shown in Figure 4.8. 


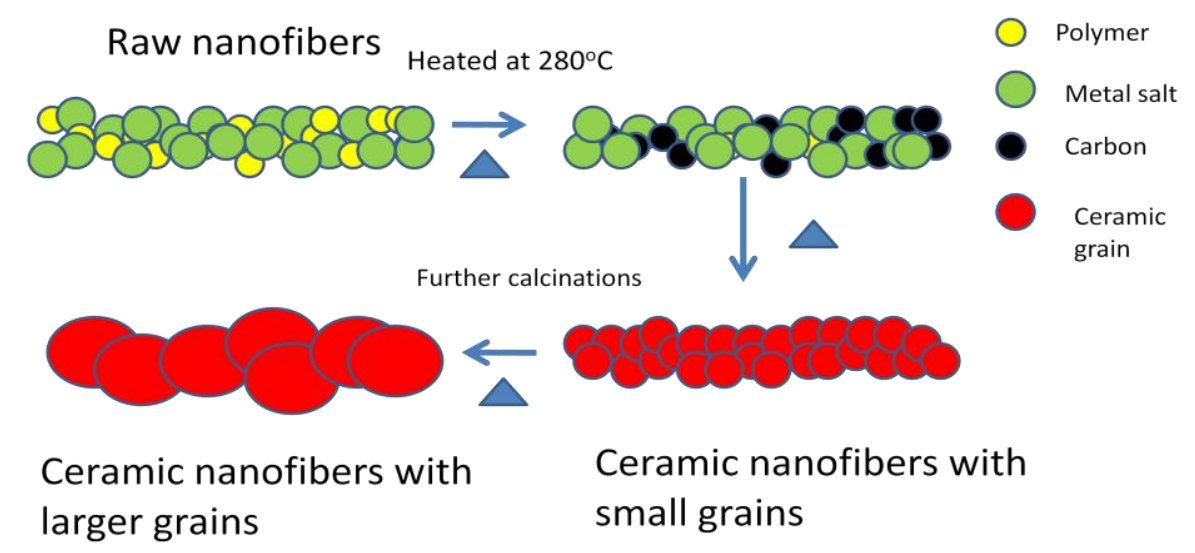

Figure 4.8 Mechanism of nanofiber formation

Based on the above values, a grain growth model was used to calculate the growth activation energy of the YSZ nano grains in the nanofibers. Normally, the relationship of the grain size and the calcination temperature can be written as

$$
D_{t}=D_{o} \times e^{\left(-\frac{Q}{R T}\right)}
$$

In which $D_{o}$ and $D_{t}$ are the initial and the final grain size, $Q$ is the activation energy of the grain growth, $\mathrm{R}$ and $\mathrm{T}$ are the gas constant $(\mathrm{kJ} / \mathrm{K} \mathrm{mol})$ and the calcination temperature $(\mathrm{K})$ [19]. Figure 4.9 is the plot of the grain size vesus different calcination temperatures, the slope is used to calculate the $\mathrm{Q}$ and the value is $32.91 \mathrm{~kJ} / \mathrm{mol}$.

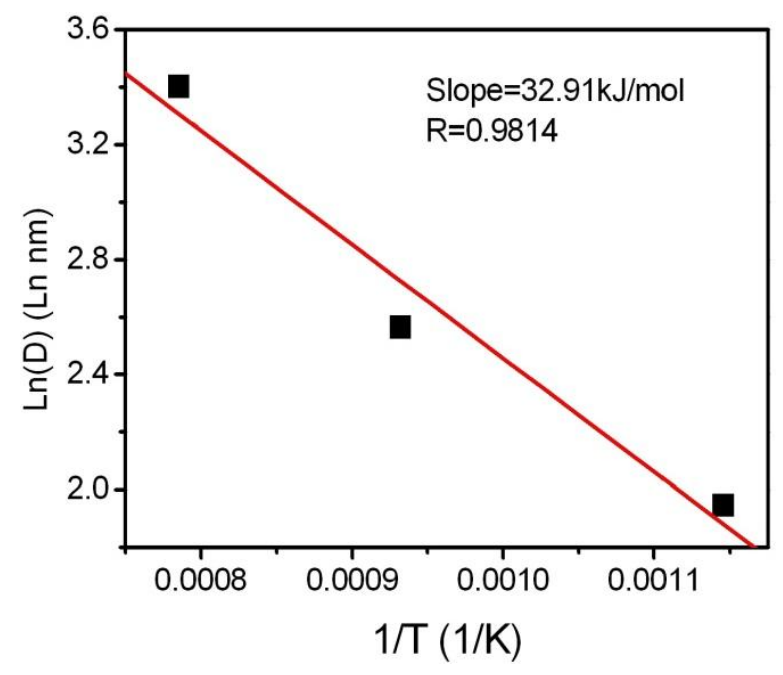

Figure 4.9 Activation energy plot for the nanograins in the YSZ nanofiber

The calculated activation energy is in the same order as Seal et al. reported (13.9kJ/mol for 3\% yttria doped zirconia) [19], but much lower than the bulk YSZ 
activation energy (288 kJ/mol for cubic YSZ and $580 \mathrm{~kJ} / \mathrm{mol}$ for tetragonal YSZ).[19-21] The difference may be attributed to the higher concentration of the oxygen vacancies in the nanocrystalline as proposed by Seal et al,[19] which is favorable for the oxygen ion transportation in SOFC application.

It should also be noted that the above discussion is a rough estimation. The YSZ phase was formed in situ when the raw nanofibers were heated, precursor decomposition as well as crystalization occur simultaneously with the grain growth process. Also intially the YSZ nano grains are embedded in the polymer/carbom matrix as shown in Figure 4.8. The polyacrylonitrile decomposition in air ends at the temperature above $600{ }^{\circ} \mathrm{C}$ [22], which implies that the grain growth might be restricted by the secondary carbon matrix surrounding the YSZ grains.

\subsection{Results of the LSM nanofibers}

LSM nanofibers were prepared similar to the YSZ nanofibers. Again a white raw nanofibers mat can be formed after the electrospinning experiments. Figure 4.10 gives the SEM image taken from such mat. Long and uniform nanofibers can be clearly seen as the YSZ sample.

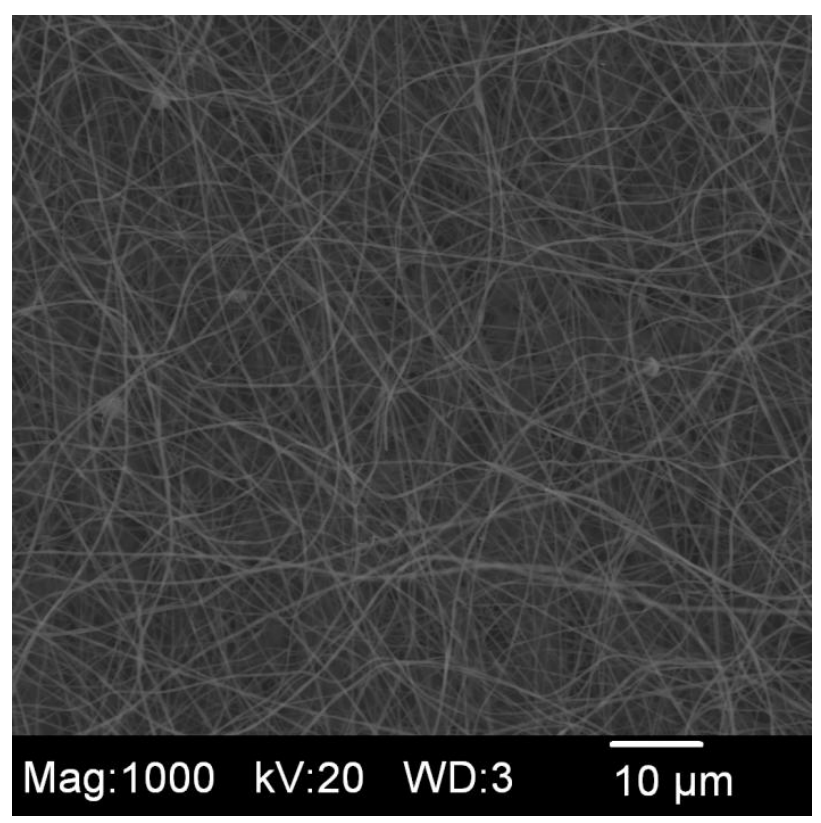

Figure 4.10 SEM image of LSM raw nanofibers 
A series of similar thermal treatments was carried for the LSM raw fibers. Figure 4.11 is the morphology of the LSM ceramic nanofibers after $600^{\circ} \mathrm{C}$ calcinations. Figure 4.11 (a) gives the low magnification SEM image shows large amount nanofibers are formed when Figure 4.11 (b) gives the closer view of several nanofibers. The diameter is estimated to be $\sim 200 \mathrm{~nm}$.
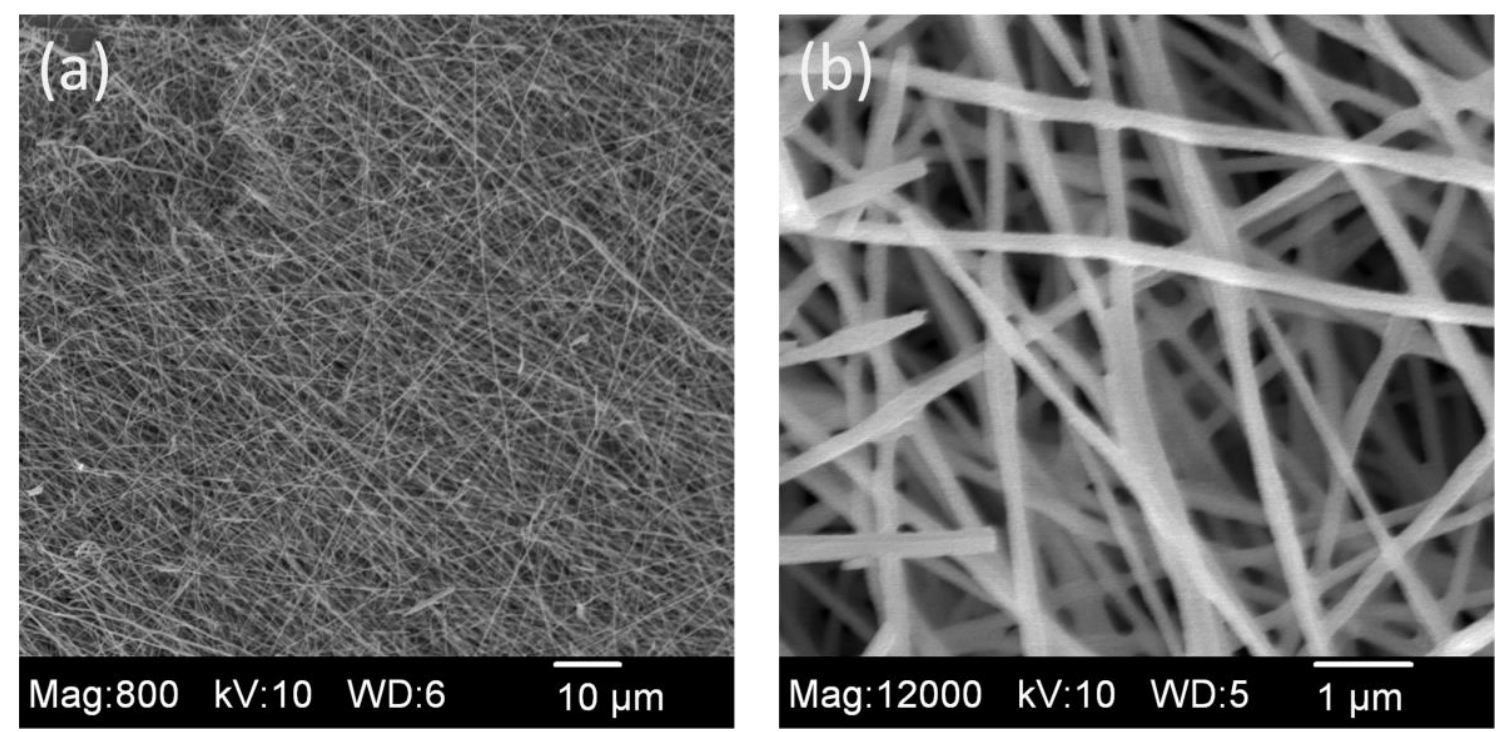

Figure 4.11 SEM images of the LSM nanofibers formed at $600^{\circ} \mathrm{C}$, (a) low magnification and (b) high magnification

The XRD characterization result of the nanofibers heated at different temperatures can be found in Figure 4.12. The perovskite LSM can be formed as low as $600^{\circ} \mathrm{C}$ with average grain size of $15 \mathrm{~nm}$. Heating at higher temperature further increases the grain size to 25 and $40 \mathrm{~nm}$ at $800^{\circ} \mathrm{C}$ and $1000^{\circ} \mathrm{C}$, respectively. 


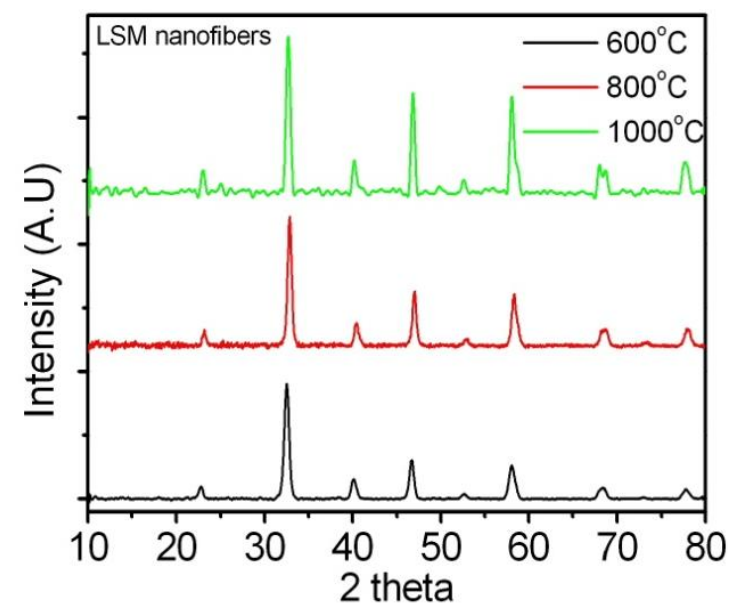

Figure 4.12 XRD pattern of the YSZ nanofibers obtained after different temperature heat treatment

After heating at $1000^{\circ} \mathrm{C}$, the LSM nanofibers still retained fibrous nature as the YSZ nanofibers. The SEM images of such sample are shown in Figure 4.13. Such morphology and XRD observations indicate the LSM nanofibers are formed similar to the YSZ nanofibers.
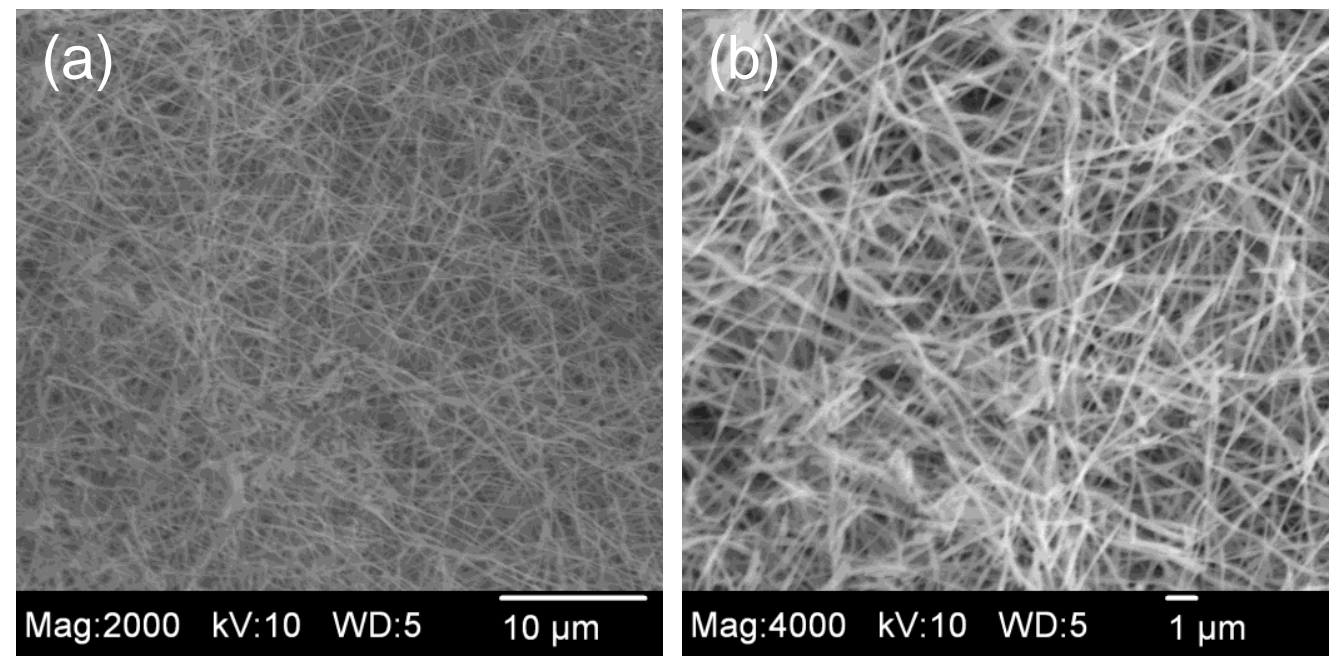

Figure 4.13 SEM images of the LSM nanofibers after $1000^{\circ} \mathrm{C}$ annealing, (a) low magnification and (b) high magnification 


\subsection{Conclusion:}

A reliable electrospinning method has been developed which can produce uniform and large quantity of nanofibers for solid oxide fuel cell electrodes application, especially the LSM and YSZ materials. It is found that the nanofibers length can reach up to several tens of microns when the diameter ranged from 100 to $200 \mathrm{~nm}$. The crystalline phases were determined as desired and can be formed as low as at $600^{\circ} \mathrm{C}$. Higher temperature heating $\left(1000^{\circ} \mathrm{C}\right)$ enlarged the grain size within the nanofiber while the fibrous structure can still retain. Such nanofibers are thermal stable under normal SOFC cathode sintering conditions, which revealed they can be potentially used as SOFC cathode. 


\section{References for Chapter 4:}

[1] S. Banerjee, A. Dan and D. Chakravorty, J. Mater. Sci., 37, 2004, 4261

[2] J. Xu, N.Q. Wu, C. Jiang, M. Zhao, J. Li, S. Li, and S. X. Mao, Small, 2, 2006, 1458

[3] M. Adachi, Y. Murata, J. Takao, J. Jiu, N. Sakamoto and F. Wang, J. Am. Chem. Soc., $126,2004,14943$

[4] N. Q. Wu, J. Wang, D. Tafen, H. Wang., J. G. Zheng, J. P. Lewis, X. Liu, S. S. Leonard and A. Manivannan, J. Am. Chem. Soc., 132, 2010, 6679

[5] J. Deng, L. Zhang, H. Dai, H. He and C. T. Au, Catal. Lett., 123, 2008, 234

[6] T. Suzuki, Z.Hasan, Y. Funahashi, T. Yamaguchi, Y. Fujishiro and M. Awano, Science, 14, 2009, 852

[7] S. B. Adler, Chem. Rev., 104, 2004, 4791

[8] J. R. Wilson, A. T. Duong, M. Gameiro, H.Y. Chen, K. Thornton, D. R. Mumm and S. A. Barnett, Electrochem. Commun., 11, 2009, 1052

[9] M. G. Bellino, J. G. Sacanell, D. G. Lamas, A. G. Leyva and N. E. W. de Reca, J. Am. Chem. Soc., 129, 2007, 3066

[10] J. Sacanell, A. G. Leyva, M. G. Bellino and D. G. Lamas, J. Power. Sources, 195, 2010, 1786

[11] G. Srinivasan and D. H Reneker, Polymer International, 36, 1995, 195

[12] D. Li and Y. N. Xia, Nano Lett., 3, 2003, 555

[13] E. A. Ponzioa, T. M. Benedettia and R. M. Torresi, Electrochimica Acta, 52, 2007, 4419

[14] A.M Azad, Mater. Lett., 60, 2006, 67

[15] Y. Kadomae, Y. Maruyama, M. Sugimoto, T. Taniguchi and K. Koyama, Fibers and Polymers, 10, 2009, 275 
[16] http://en.wikipedia.org/wiki/File:Electrospinning_setup.png

[17] W. X. Zhang, Y. Z. Wang and C. F. Sun, J. Polym. Res., 14, 2007, 467

[18] Q. Z. Cui, X. T. Dong, J. X. Wang and M. Li, J. Rare Earths, 26, 2008, 664

[19] S. Shukla, S. Seal, R. Vij, and S. Brandyopadhyay, Nano Letters, 3, 2003, 397

[20] T. G. Neigh, J. Wadsworth, J. Acta. Metall. Mater., 38, 1990, 1121

[21] Z. A. Munir, T. Ohji, Y. Hotta, and M. Singh, Innovative Processing and Manufacturing of Advanced Ceramics and Composites: Ceramic Transactions, Volume 212, pp 55

[22] C.Y. Chen, C.C. Chen, S. S. Hou, Journal of Applied Polymer Science, 115, 2010, 416 


\section{Chapter 5: YSZ Nanofibers as Porous Scaffold for SOFC Cathode}

\subsection{Introduction:}

LSM/YSZ mixture is the prevailing SOFC cathode material has been studied so far. Conventional SOFC cathodes are fabricated by mechanically mixing the LSM with YSZ powders and sintering them on the electrolyte at high temperature $\left(\geq 1000{ }^{\circ} \mathrm{C}\right) \cdot[1,2]$ The composition distribution and the architecture of the electrode are difficult to control with this method. Efforts have been made to optimize the composition and the structure of cathodes in order to obtain acceptable polarization resistance at lower temperature by using nanomaterials [3] or mixed ion/electron conductors [4]. One alternative cathode fabrication process is the infiltration method. In such method micron-sized particulate material is initially sintered to form a porous scaffold and then the secondary material is infiltrated into the scaffold in various liquid forms and further treated to form a composite electrode. A sketch map of such process can be found in Figure 5.1(a).
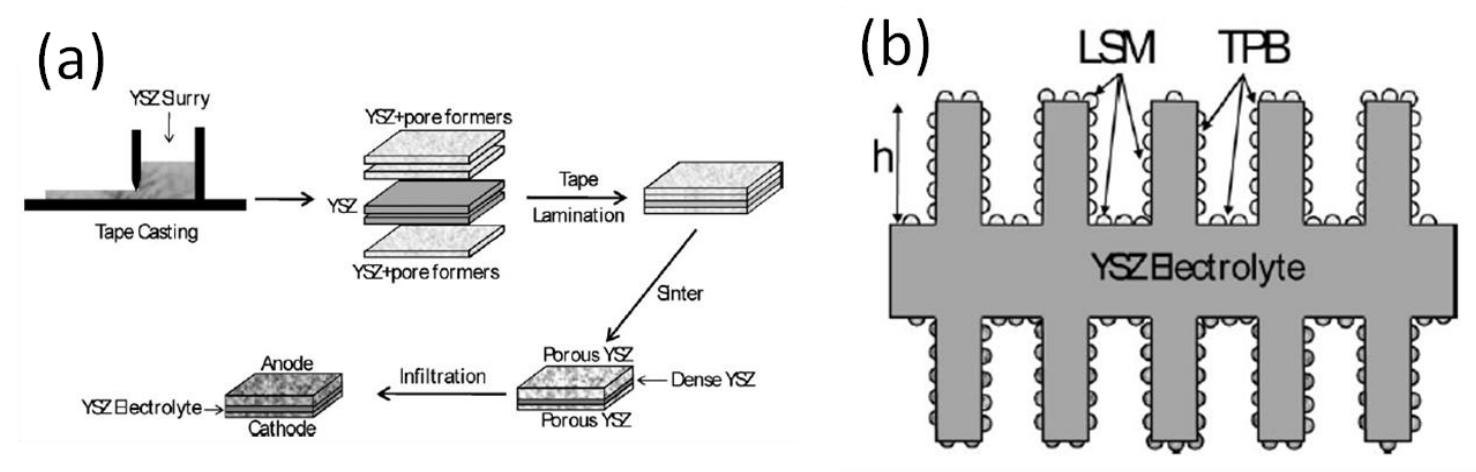

Figure 5.1 (a) Process of the electrode fabrication using infiltration method and (b) ideal cathode microstructure [5]

The infiltration method offers following advantages over the conventional co sintering method:

1. Extending the reaction area. As shown in Figure $5.1 \mathrm{~b}$, an ideal LSM/YSZ structure is proposed by using the infiltration method, the embedded LSM nanoparticles on the YSZ backbones could significantly increasing the TPB sites, which are important for improving the cathode performance, especially for the LSM/YSZ mixture. 
2.Offering flexible cathode materials combinations. In conventional method, the composite materials were sintered at the same temperature, which may cause interaction between the compounds. For example, LSC and YSZ would react above $900^{\circ} \mathrm{C}$ to form high insulating phase $\mathrm{SrZrO}_{3}[6]$, which eliminates the possibility of preparing LSC/YSZ composite cathode. However, using infiltration method, it is feasible to sinter the YSZ backbone at higher temperature, and then the LSC was infiltrated and formed at lower temperature. The high temperature interaction could be avoided; therefore more combinations of composite cathodes can be fabricated without forming secondary phase.

Several composite SOFC cathodes have been made by the infiltration method, including LSM/YSZ [7, 8], Pd/YSZ [9], LSCF/YSZ [10], LSM/SSC [11], YDC/LSCF [12], and LSF/YSZ [6, 13-14]. It has been found that a minimum loading of secondary material is required to form the connected nanoparticles network on the pore wall of the scaffold [5]. However, a large number of repetitions (even up to 20 times) are typically needed to achieve the required loading of secondary material $[5,9]$. Unfortunately, the pores could be filled during the multiple steps of infiltration, leading to limited gas diffusion within the cathode.

In this chapter, we will demonstrate using YSZ nanofibers as the cathode scaffold for further infiltration of LSM nanoparticles. Use of one-dimensional (1-D) fibers rather than zero-dimensional (0-D) particles as the cathode scaffold offers several advantages. First, the nanofibers naturally form a highly porous scaffold without further addition of any filler. In contrast, conventional 0-D particles need filler (usually graphite or polymer beads) to generate a porous electrode scaffold for the follow-up infiltration. Second, only a single infiltration step is needed to achieve a high loading of secondary material on the nanofiber skeleton while a large number of repetitions of infiltration steps are needed to achieve the same loading on the conventional scaffold made of 0-D particles. Third, the connected LSM nanoparticles network is easily formed on the YSZ nanofibers, leading to a nano-porous LSM shell on the YSZ nanofiber core. Fourth, electrolyte-electrode thermal expansion coefficient matching tolerance is relaxed and greater flexibility in cathode material selection is possible. Finally, the polarization resistance of cathode is reduced, thus increasing the power density of SOFC and allowing the cell running at 
lower temperature, which is also essential to suppress the anode degradation by impurities as discussed previously.

\subsection{Experimental Detail:}

\subsubsection{Regent}

YSZ nanofibers were prepared as described in Chapter 4. The fibers were heated at $600^{\circ} \mathrm{C}$. Lanthanum acetate hydrate $(\mathrm{La}(\mathrm{CH} 3 \mathrm{COO}) 3 \cdot 1.5 \mathrm{H} 2 \mathrm{O})$, Strontium acetate hydrate $\left(\mathrm{Sr}\left(\mathrm{CH}_{3} \mathrm{COO}\right)_{2} \cdot 0.5 \mathrm{H}_{2} \mathrm{O}\right)$, Manganese acetate hydrate $\left(\mathrm{Mn}\left(\mathrm{CH}_{3} \mathrm{COO}\right)_{2} \cdot 4 \mathrm{H}_{2} \mathrm{O}\right)$ and N'N-dimethylformamide (DMF) were purchased from Alfa Acer. Polyacrylonitrile (PAN) was purchased from Sigma Aldch. Ink vehicle (NexTech Materials, Ltd. Lewis Center, $\mathrm{OH})$ was used for preparing YSZ ink. YSZ substrates $(150 \mu \mathrm{m}$ thick, $20 \mathrm{~mm}$ diameter, NexTech Materials, Ltd. Lewis Center, $\mathrm{OH}$ ) were used as the electrolyte.

\subsubsection{Cathode Fabrication}

The YSZ nanofibers were mixed with ink vehicle in certain weight ratio. It is found that unlike the powders, a 1:8 weight ratio (YSZ to solvent) is necessary to prepare a viscous liquid ink. In our experiments, the ratio was fixed at 1:10. The ink was then pained on the YSZ substrate. The diameter of the electrode is fixed as $7 \mathrm{~mm}$, therefore the active area is $0.37 \mathrm{~cm}^{2}$, and the electrochemistry data treatment was based on that value. The cell was then sintered at $800{ }^{\circ} \mathrm{C}$ for 3 hours to form the YSZ nanofiber network scaffold. The mass difference before and after the YSZ fiber scaffold formation was monitored and typically $0.4 \mathrm{mg}$ YSZ nanofibers was used.

The LSM precursor used for infiltration was prepared by dissolving $1 \mathrm{M}$ of $\mathrm{La}, \mathrm{Sr}$, and $\mathrm{Mn}$ acetates in DMF with $6 \mathrm{wt} \%$ PAN to achieve the desired stoichiometry of $\mathrm{La}_{0.8} \mathrm{Sr}_{0.2} \mathrm{MnO}_{3}$. A pipette was used to apply the necessary amount of LSM precursor to the YSZ nanofibers electrode for the desired weight The SOFC cells heated to $650{ }^{\circ} \mathrm{C}$ and held for $1 \mathrm{~h}$. Three sets of LSM/YSZ nanofiber composite cathodes were prepared with the LSM weight content of $25 \%, 50 \%$ and $75 \%$ in the total cathode mass, which are

denoted as LSM25/YSZ, LSM50/YSZ and LSM75/YSZ. The composite cathode fabrication process is schematically illustrated in Figure 5.2. 


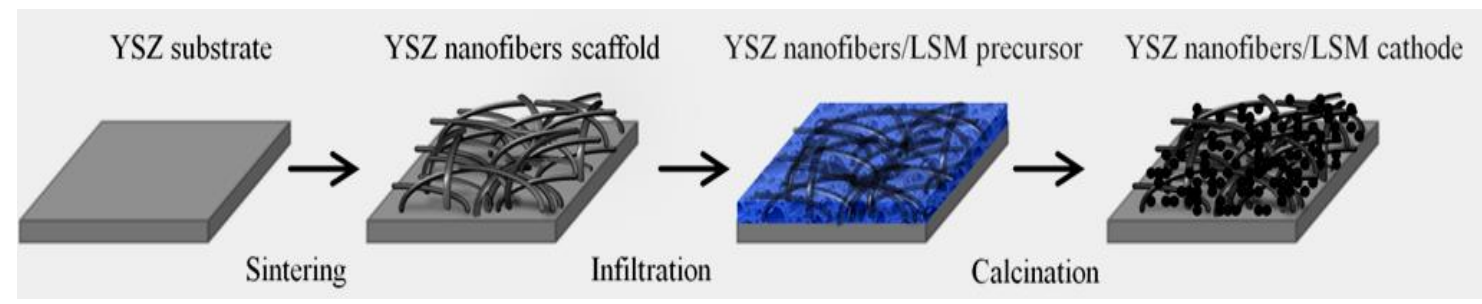

Figure 5.2 Fabricating process of the LSM /YSZ nanofibers composite cathode

\subsection{3: Electrochemical Characterization}

A three-electrode half cell was used for electrochemical testing as shown in Figure 5.3. As mentioned above, the LSM/YSZ composite was employed as the working electrode (WKG). Platinum paste was applied on the other side of the YSZ electrolyte and sintered at $700{ }^{\circ} \mathrm{C}$ as the counter (CTR) and the reference (REF) electrodes. A silver mesh was used as the current collector. Impedance spectra were measured in air from 700 ${ }^{\circ} \mathrm{C}$ to $900{ }^{\circ} \mathrm{C}$ with an interval of $50{ }^{\circ} \mathrm{C}$ using an impedance/gain phase analyzer (Solartron 1260) and an electrochemical interface (Solartron 1287) at AC amplitude of $10 \mathrm{mV}$ with frequency range from $300 \mathrm{kHz}$ to $0.1 \mathrm{~Hz}$.

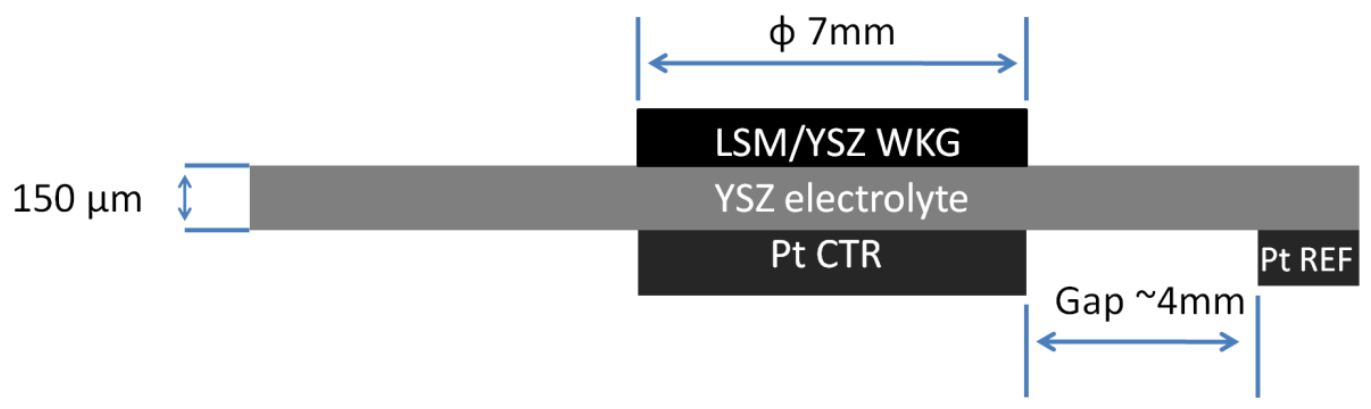

Figure 5.3 The configuration of the three-electrode half cell

\subsubsection{Materials Characterization}

The morphology and the composition of the cathode were examined by using a Hitachi S-4000 scanning electron microscopy (SEM) equipped with energy dispersive Xray spectroscopy (EDX). A 10-20 nm thick gold film was deposited to enhance the conductivity. The crystalline structures were determined by a Panalytical X-ray diffractometer (XRD) equipped with a thin film stage. 


\subsection{Result and Discussion:}

Figure 5.4 (a) shows the SEM image of the YSZ nanofiber scaffold. The nanofibers are around $200 \mathrm{~nm}$ in diameter and more than tens of microns long. The nanofibers have formed a porous network in three-dimensions. After LSM was infiltrated to the YSZ nanofiber skeleton and the LSM50/YSZ cathode was calcined at $650{ }^{\circ} \mathrm{C}$, the continuous nanofiber scaffold was retained (Figure 5.4 (b) and 5.4 (c)). The nanofibers appeared coarser than before infiltration, which was due to the deposition of LSM on the YSZ nanofiber surface. A high magnification of SEM image reveals that thin membranes were formed in the pore area surrounded by the nanofiber backbone (Figure 5.4(c)). But these membranes were highly porous, which enabled the gas transport through the whole cathode. The SEM image of the cross-section of the LSM50/YSZ cathode confirms that the whole cathode was highly porous (Figure 5.4 (d)). The adhesion between the LSM/YSZ electrode and the YSZ electrolyte was good. This picture also clearly shows that connected $80 \mathrm{~nm}$ sized LSM nanoparticles were supported on the YSZ nanofibers to form a porous LSM shell on the YSZ nanofiber core. EDX analysis was performed on the LSM50/YSZ nanofiber cathode in order to examine the composition. The EDX spectrum taken on the nanofiber surface shows that $\mathrm{Zr}$ and $\mathrm{Y}$ are dominant and a small amount of $\mathrm{La}, \mathrm{Sr}$ and $\mathrm{Mn}$ is present on this area while the porous membrane between the nanofibers mainly contains La, Sr, and Mn (Figure 5.5). 


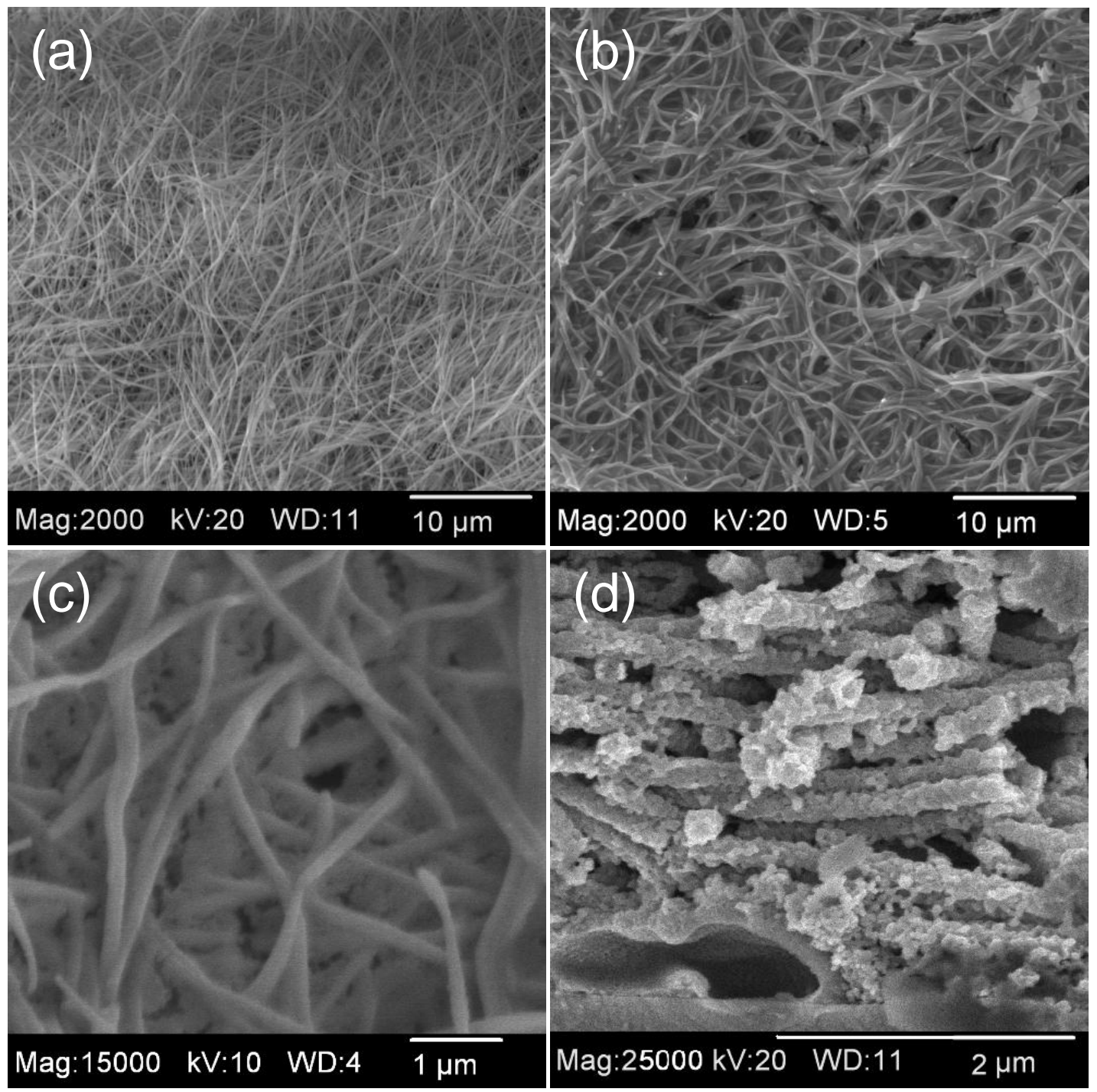

Figure 5.4 SEM images of the cathode; (a) YSZ nanofiber scaffold before infiltration, (b) top surface of LSM50/YSZ composite cathode after infiltration and calcination at $650{ }^{\circ} \mathrm{C}$, (c) a close view of the top surface of the LSM50/YSZ composite cathode, and (d) crosssection of the LSM50/YSZ composite cathode 

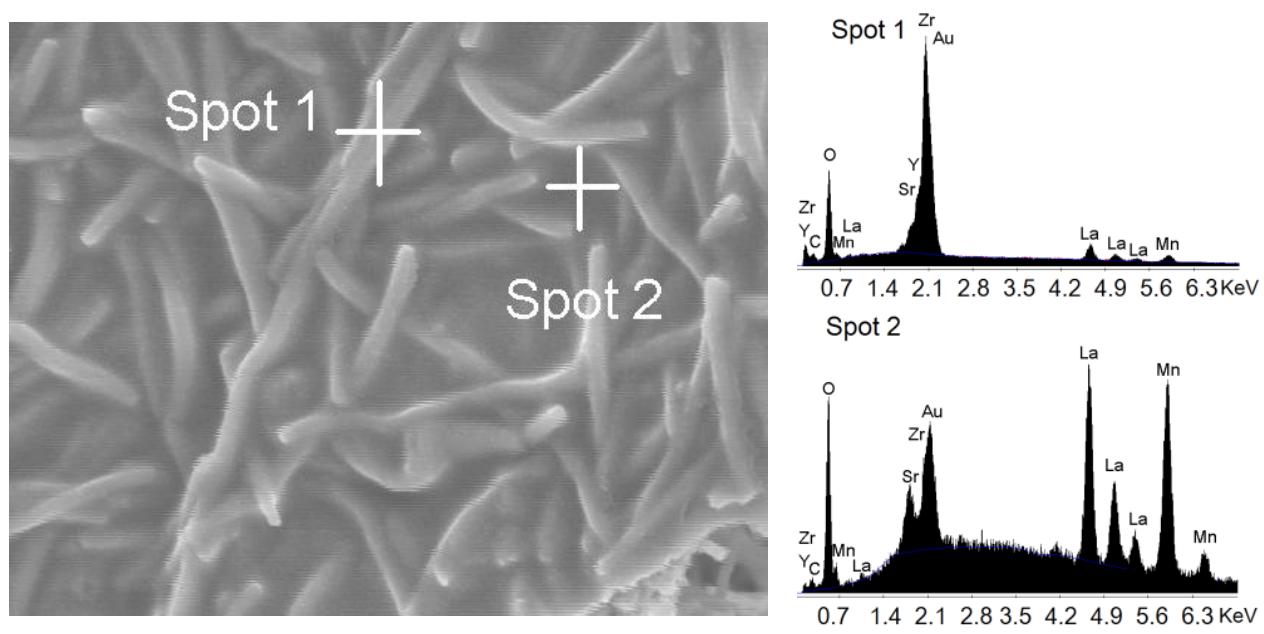

Figure 5.5 EDX analysis of the LSM50/YSZ cathode; Spot 1 is pointed on the nanofiber, and Spot 2 is obtained from the membrane between the nanofibers

XRD characterization was carried out to examine the crystal structure of the cathode. The YSZ nanofiber scaffold, which was prepared by electrospinning and sintering at $800{ }^{\circ} \mathrm{C}$, had a cubic zirconia phase, as confirmed by the XRD analysis in Figure 5.6.After LSM was infiltrated into the YSZ nanofiber scaffold and calcined at 650 ${ }^{\circ} \mathrm{C}$, the LSM50/YSZ nanofiber composite contained the mixture of the cubic zirconia and the perovskite LSM.

The successful formation of the porous LSM shell on the YSZ nanofiber core is partially due to the infiltration precursor used. The $\mathrm{pH}$ value of the LSM infiltration precursor was measured to be 6.7, which is higher than the reported isoelectric point (4.8) of YSZ [13]. When the YSZ nanofibers were soaked in the LSM precursor solution during the infiltration process, the metal cations are attracted to the negatively charged YSZ nanofiber surface. On the other hand, the infiltration precursor contains PAN as the polymer binder. The high tension force of the viscous liquid assists the adhesion of the LSM precursor on the YSZ nanofiber scaffold. 


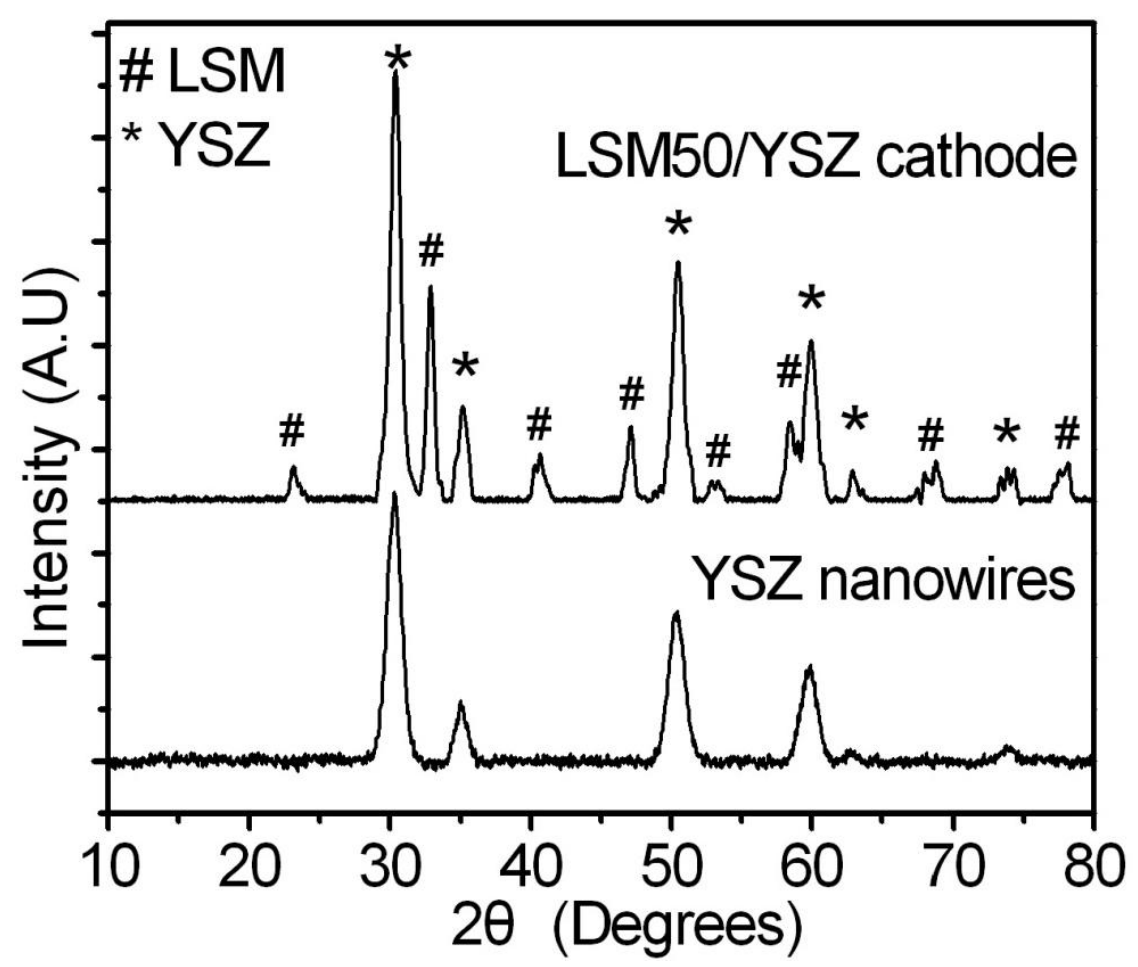

Figure 5.6 XRD patterns of the YSZ nanofiber scaffold and the LSM50/YSZ nanofiber composite cathode

Figure 5.7 shows the impedance spectra taken from the SOFC half cell based on LSM50/YSZ in air at different temperatures. The polarization resistance was determined by taking the separation between the high and the low frequency intersections on the $\mathrm{Z}_{\text {real }}$ axis. The polarization resistance values of the LSM50/YSZ cathode with the LSM nanoparticles supported on the YSZ nanofiber scaffold were compared to those of the conventional cathode made of the mixture of LSM and YSZ powder (as listed in Table 5.1). Although the chemical composition of the two types of cathodes was identical, the developed LSM/YSZ nanofiber cathode exhibited much lower polarization resistance than that of conventional powder cathode. For example, at $900^{\circ} \mathrm{C}$ the polarization resistance was $0.05 \Omega \cdot \mathrm{cm}^{2}$ and $0.48 \Omega \cdot \mathrm{cm}^{2}$ for the newly developed cathode and the conventional one, respectively. When the operating temperature dropped to $750{ }^{\circ} \mathrm{C}$, the polarization resistance of the nanofiber-based cathode increased to $0.48 \Omega \cdot \mathrm{cm}^{2}$ but remained lower than the $2.85 \Omega \cdot \mathrm{cm}^{2}$ measured on the conventional cathode. The polarization resistance of the nanofiber-based LSM/YSZ cathode is comparable to the 
best data $\left(0.3 \Omega \cdot \mathrm{cm}^{2}\right.$ at $\left.700{ }^{\circ} \mathrm{C}\right)$ using the similar composition reported in the literature [15].

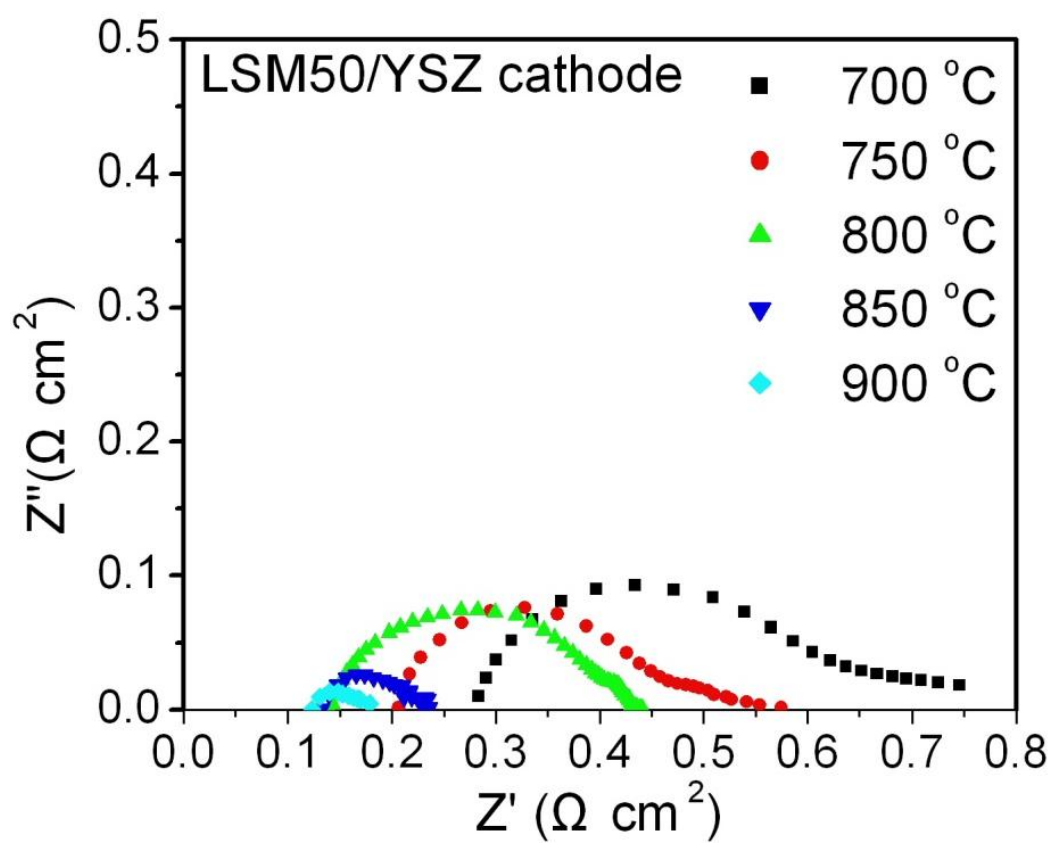

Figure 5.7 Nyquist plots of impedance taken from the LSM50/YSZ composite cathode in which the LSM nanoparticles are supported on the YSZ nanofiber scaffold

\begin{tabular}{|c|c|c|c|}
\hline $\begin{array}{l}\text { Temperature } \\
\left({ }^{\circ} \mathrm{C}\right)\end{array}$ & $\begin{array}{l}\text { YSZ/LSM 50 } \\
\left(\Omega \cdot \mathrm{cm}^{2}\right)\end{array}$ & $\begin{array}{l}\text { Conventional LSM/YSZ } \\
\text { powder cathode } \\
\left(\Omega \mathrm{cm}^{2}\right)\end{array}$ & $\begin{array}{l}\text { Data reported } \\
\left(\Omega \cdot \mathrm{cm}^{2}\right)(\text { Ref. 15) }\end{array}$ \\
\hline 700 & 0.48 & 2.85 & 0.30 \\
\hline 750 & 0.32 & 1.21 & \\
\hline 800 & 0.27 & 1.01 & 0.14 \\
\hline 850 & 0.10 & 0.66 & \\
\hline 900 & 0.05 & 0.49 & \\
\hline
\end{tabular}

Table 5.1 Polarization resistance of different cathodes

The effect of the LSM content on the polarization of the LSM/YSZ composite cathode was investigated. When the weight ratio of LSM to YSZ was 1:1, the LSM/YSZ composite electrode showed the best electrochemical activity due to the maximized 
triple-phase boundary in Figure 5.8. This is in consistent with the result reported previously [16]. Also the comparison of the cathode SEM images with different composition in this study, a relationship between the microstructure and electrochemical perforce can be found. When the LSM content is as low as 25\% wt as shown in Figure 5.9 (a), only small portion of the YSZ nanofibers are connected by LSM nano membrane, which indicates a reduced number of TPB. When the ratio increases to $75 \%$ in Figure 5.9 (b), the whole surface is covered by LSM with some large aggregates, the YSZ nanofibers as well as the pores can't be identified; therefore the gas diffusion channels are blocked which leads the performance degradation.

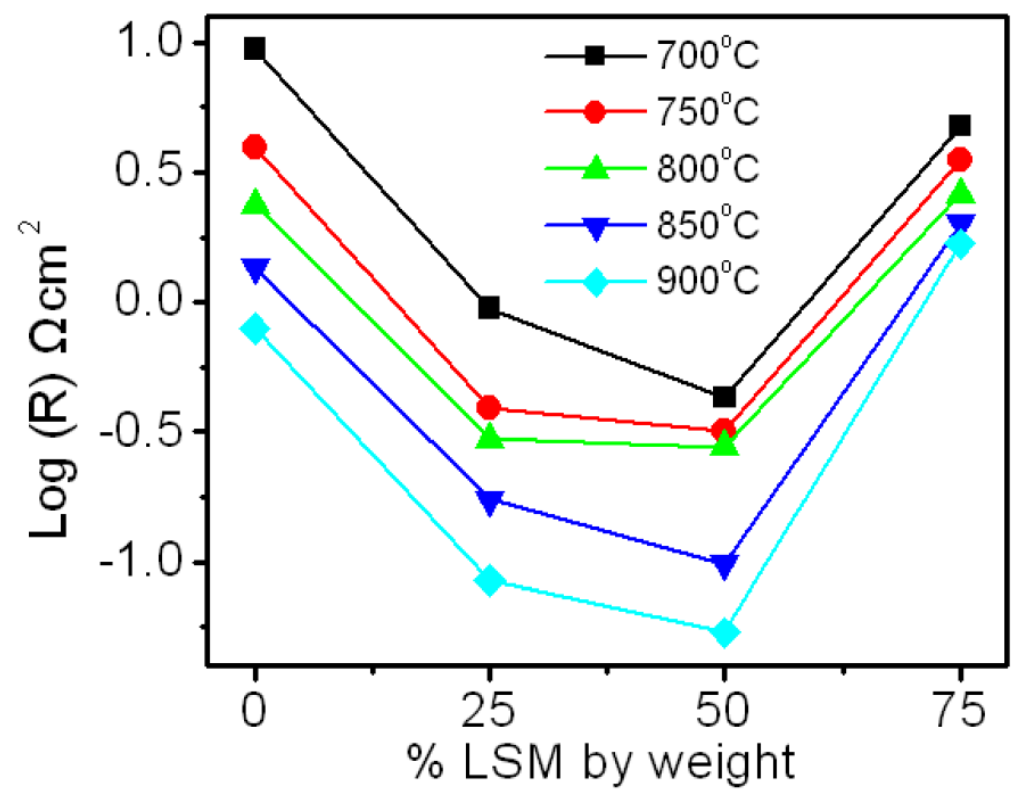

Figure 5.8 Polarization resistances as a function of the LSM content in the YSZ/LSM composite cathode at different temperatures 

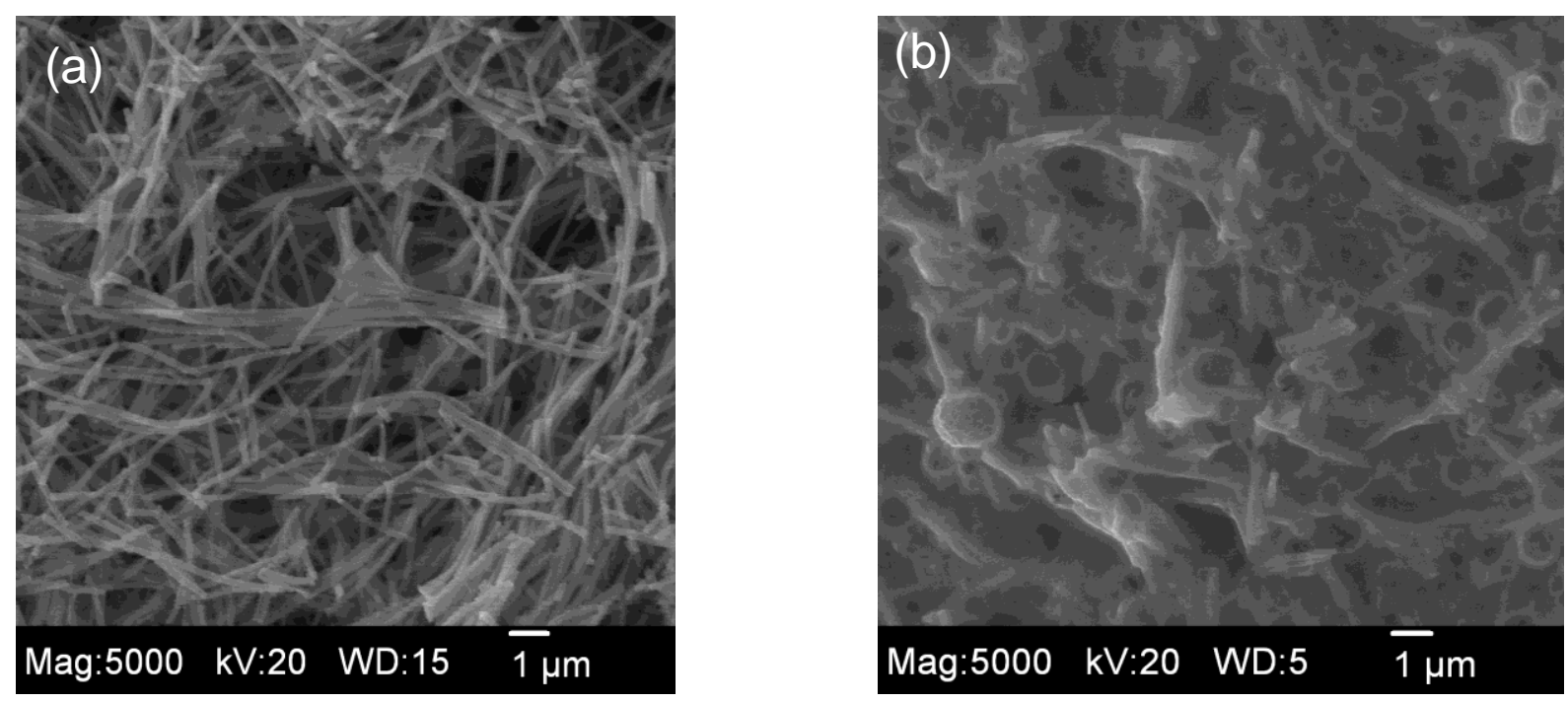

Figure 5.9 SEM images of the different cathodes: (a) LSM25/YSZ and (b) LSM75/YSZ

The nanofiber-based cathode exhibits much lower polarization resistance than the conventional LSM/YSZ powder electrode. Such performance enhancement could be attributed to the electrode microstructure as well as the materials. From the view point of the microstructure, the YSZ nanofibers offer a highly porous network, which favors gas diffusion. In addition, the porous nanofiber skeleton enables a large amount of LSM precursor to be infused with only a single infiltration step. As a result, the connected LSM nanoparticles are formed on the YSZ nanofiber surface. This is a desired structure resulting from the infiltration process [5]. Such architecture provides a large number of active reaction sites.

Furthermore, it is well known that increasing the number of TPB sites can promote the charge transfer ability and increase the number of the active reaction sites, which reduce the total polarization resistance of the cathode [17]. However, about half of the TPB in the conventional LSM/YSZ powder electrode is considered to be "non-percolated" because of the absence of contiguous charge transfer pathways [18-20]. In the developed cathode, the long one-dimensional (1-D) fibers form a continuous network that acts as a "highway" for oxygen ion transport. Owing to reduced contact resistance, 1-D nanostructures show better charge transport ability than 0-D nanomaterials [21-23]. The nanofiber network in our design ensures the transport of the oxygen ion from the whole 
electrode to the electrolyte without interruption due to the presence of the continuous YSZ nanofibers. In addition, the porous LSM membrane can continuously transfer electrons throughout the whole cathode. Therefore, the interface at the LSM membrane, YSZ nanofibers, and oxygen gas can be considered as the "percolated" electrochemically active TPB site. In other words, the TPB sites are extended throughout the whole electrode. A rough estimation is proposed as below:

Considering the average diameter of the single YSZ nanofiber (d) is $200 \mathrm{~nm}$, and the total YSZ mass (m) of $2 \mathrm{mg}$ in the cathode scaffold with a dimension of $0.3 \mathrm{~cm}^{2}$ in planar area (A) and $30 \mu \mathrm{m}$ in thickness (t). The total YSZ nanofiber length (L) and the interface area density of the YSZ-pore (D) in certain volume could be estimated using the following equations:

$$
\begin{array}{r}
L=\frac{m}{\rho \times A \times t \times \pi(d / 2)^{2}}=12.6 \mu m^{-2} \\
D=\frac{m}{\rho \times A \times t \times \pi(d / 2)^{2}} \times d \times \pi=7.91 \mu m^{-1}
\end{array}
$$

In which $\rho$ is the theoretical density of the YSZ $\left(5.6 \mathrm{~g} / \mathrm{cm}^{3}\right)$ when assuming the YSZ nanofibers are fully dense and the surface is smooth.

From the above calculation, the YSZ-pore interface area density $D$ is higher than the reported value $\left(2.60 \mu \mathrm{m}^{-1}\right)$ when using $500 \mathrm{~nm}$ YSZ particles, which indicates a larger specific porosity [18].

After infiltration LSM into the YSZ backbone, a thin LSM coating is created on the YSZ nanofiber as shown in Figure 5.4. From Figure 5.4 (a) and (b), it can be seen that the $50 \%$ mass of LSM is sufficient to cover the YSZ scaffold as well as form thin membranes within the nanofibers. Considering the definition of TPB, the contact lines of LSM and YSZ can be used to estimate the TPB length. In an ideal case, a LSM membrane is parallel contacted with a YSZ nanofiber as shown in Figure 5.10, therefore the TPB can be calculated as $2 \times l$, where $l$ is the length of the YSZ fiber. The overall TPB density in the cathode can be calculated as $2 \times L=25.2 \mu \mathrm{m}^{-2}$, which is about 5 times high compared with the recent value derived from 3-D reconstruction of LSM/YSZ powder cathode $\left(4.93 \mu^{-2}\right)[19]$. It should be noted that other parameters such as the surface roughness of the YSZ nanofibers and the tortuosity of the LSM coating along the YSZ nanofiber should also be considered in a more accurate model. 

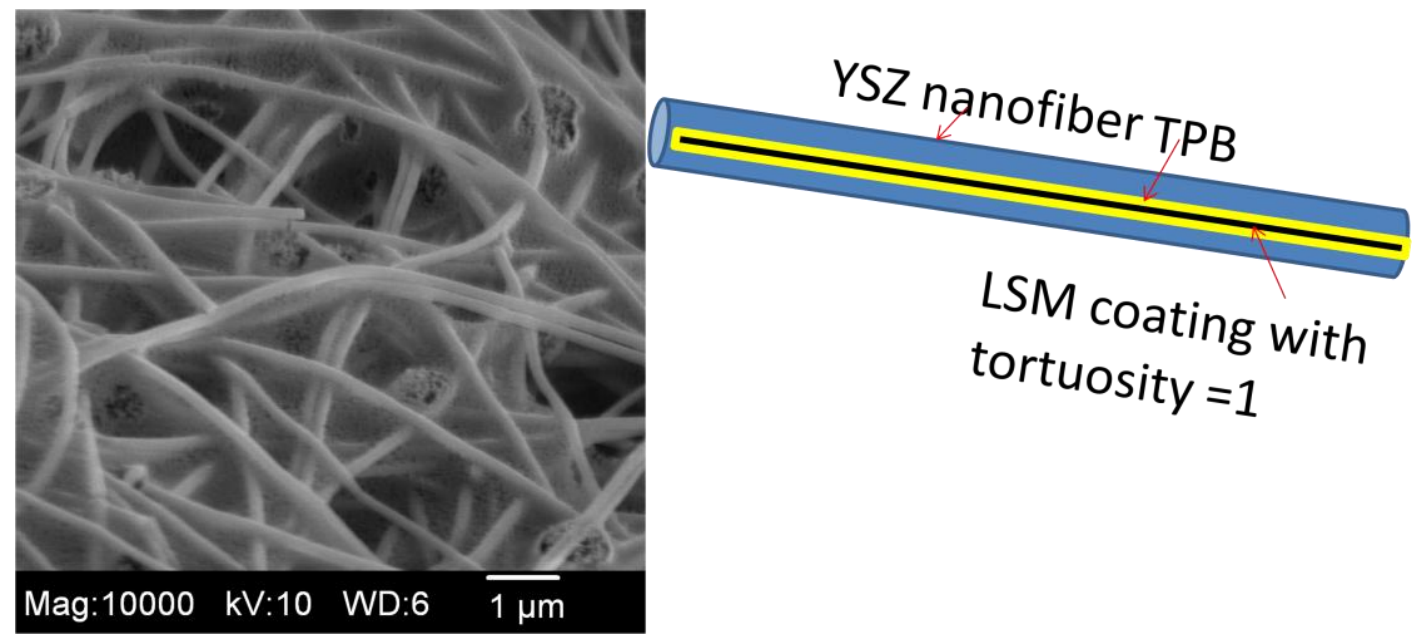

Figure 5.10 A schematic used to estimate the TPB length in the cathode

Another possible advantage may be brought from the nanofiber is the enhanced ionic conductivity. Small polycrystalline grains compose the YSZ nanofiber and the grain size is below $30 \mathrm{~nm}$ as discussed in the previous chapter. The large relative ratio of grain/grain boundary will enhance the oxygen ion conductivity of the YSZ as proposed by Tuller et al $[24,25]$. Recent results also indicate nanocrystalline YSZ has higher oxygen surface exchange coefficient and diffusion rate [26]. It is therefore believable that the higher ionic transportation property should also be accounted for the enhanced performance of the YSZ nanofibers based cathode.

\subsection{Conclusion:}

Our results have demonstrated that a high performance SOFC cathode can be achieved by utilizing the YSZ nanofiber scaffold for infiltration of the LSM electrocatalyst. The highly porous cathode formed by the nanofiber network allows the gas transport. The continuous nanowires provide a "highway" for charge transfer. The connected LSM nanoparticles on the YSZ nanofibers provide a unique structure with increased "percolated" TPB sites, leading to an enhanced oxygen reduction reaction. A connection between the electrochemical performance and the microstructure has been analyzed. 


\section{References for Chapter 5:}

[1] S. Bebelis, N. Kotsionopoulos, A. Mai and F. Tietz, J. Appl. Electrochem., 37, 2007, 15

[2] Y. J. Leng, S. H. Chan, K. A. Khor and S. P. Jiang, J. Appl. Electrochem., 34, 2004, 409

[3] M. Mamak, G. S. Metraux, S. Petrov, N. Coombs, G. A. Ozin and M. A. Green, J. Am. Chem. Soc., 125, 2003, 5161

[4] Z. Shao and S. M. Haile, Nature, 431, 2004, 170

[5] J. M. Vohs and R. J. Gorte, Adv. Mater., 21, 2009, 943

[6] S. P. Simner, J. P. Shelton, M. D. Anderson and J. W. Stevenson, Solid State Ionics, $161,2003,11$

[7] T. Z. Sholklapper, C. Lu, C. P. Jacobson, S. J. Visco and L. C. De Jonghe, Electrochem. Solid-State Lett., 9, 2006, A376

[8] Y. Huang, J. M. Vohs and R. J. Gorte, Electrochem. Solid-State. Lett., 9, 2006, A237

[9]F. Liang, J. Chen, J. Cheng, S. P. Jiang, T. He, J. Pu and J. Li, Electrochem.Commun., 10, 2008, 42

[10] J. Chen, F. Liang, L. Liu, S. P. Jiang, B. Chi, J. Pu and J. Li, J. Power Sources, 2008, 183,586

[11] T. Z. Sholklapper, V. Radmilovic, C. P. Jacobson, S. J. Visco and L. C. De Jonghe, Electrochem. Solid-State Lett., 10, 2007, B74

[12] T. Z. Sholklapper, V. Radmilovic, C. P. Jacobson, S. J. Visco and L. C. De Jonghe, Nano Lett., 7, 2007, 2136

[13] A. Barbucci, M. Viviani, M. Panizza, M. Delucchi and G. Cerisol, J. Appl. Electrochem., 35, 2005, 399 
[14] C. L. Tomas and S. W.Sofie, J. Power Sources, 174, 2007, 221

[15] S. Bebelis, N. Kotsionopoulos, A. Mai, F. Tietz, J. Appl. Electrochem. 2007, 37, 15

[16] A. Barbucci, M. Viviani, M. Panizza, M. Delucchi, G. Cerisol, J. Appl. Electrochem. $2005,35,399$

[17] S. B. Adler, Chem. Rev., 104, 2004, 4791

[18] J. R. Wilson, A. T. Duong , M. Gameiro, H.Y. Chen, K. Thornton, D. R. Mumm and S. A. Barnett, Electrochem. Commun., 11, 2009, 1052

[19] J. R. Wilson, W. Kobsiriphat, R .Mendoza, H. Y. Chen, J. M. Hiller, D. J. Miller, K. Thornton, P. W. Voorhees, S. B. Adler and S. A. Barnett, Nat. Mater., 5, 2006, 541

[20] P. R. Shearing, J. Golbert, R. J. Chater and N. P. Brandon, Chem. Eng. Sci., 64, 2009,3928

[21] M. Adachi, Y. Murata, J. Takao, J. Jiu, N. Sakamoto and F. Wang, J. Am. Chem. Soc., 126, 2004, 14943

[22] J. B. Baxter and E. S. Aydil, Appl. Phys. Lett., 86, 2005, 053114

[23] N. Q. Wu, J. Wang, D. Tafen, H. Wang., J. G. Zheng, J. P. Lewis, X. Liu, S. S.

Leonard and A. Manivannan, J. Am. Chem. Soc., 132, 2010, 6679

[24] X. D. Zhou and W. Huebner, Applied Physics Letters, 79, 2001, 3512

[25] H. L. Tuller, Solid State Ionics, 131, 2000, 143

[26] G. Knöner, K. Reimann, R. Röwer, U. Södervall, and H. Schaefer, Proceedings of the National Academy of Sciences, 100, 2003, 3870 


\section{Chapter 6: Characterization of the LSCF Nanofibers Cathode}

\subsection{Introduction:}

Traditional SOFC cathode is consisted of LSM $\left(\mathrm{La}_{1-\mathrm{x}} \mathrm{Sr}_{\mathrm{x}} \mathrm{MnO}_{3}\right)$ and YSZ (yttria stabilized zirconia), in which the electron and oxygen ion transported in separated ways $[1,2]$. As discussed in the previous chapters, the electrochemical reactions therefore is restricted at the TPB (three phase boundary) where electrons from LSM, oxygen ions from YSZ and $\mathrm{O}_{2}$ all present. Such cathode needs high temperature $\left(>800^{\circ} \mathrm{C}\right)$ for acceptable performance, therefore the application of SOFC is restricted. Besides the LSM/YSZ cathode, new cathode materials with mixed ion and electron conductance (MIEC) are developed for intermediate temperature $\left(600^{\circ} \mathrm{C}-750^{\circ} \mathrm{C}\right) \mathrm{SOFC}$ as mentioned in Chapter 2. Such cathodes can largely extend the active reaction region to the whole gas/cathode interface. Among these materials, LSCF $\left(\mathrm{La}_{1-\mathrm{x}} \mathrm{Sr}_{\mathrm{x}} \mathrm{Co}_{\mathrm{y}} \mathrm{Fe}_{1-\mathrm{y}} \mathrm{O}_{3}\right)$ is considered as one of the promising candidates because of its high electron conductivity, oxygen reduction catalytic property, as well as the structure stability [3, 4].

Considering the MIEC basic properties, increasing the surface area as well as improving the charge transport property could be beneficial for enhanced electrode performance. Based this, 1-D LSCF nanofibers would be good choice for optimizing the cathode microstructure. Owing large surface/volume ratio, the reaction area can be extended significantly. The nano grains in the fibers could have enhanced oxygen vacancies concentration, the long continued nanofibers can be considered as charge transfer highway which improves the ionic and electronic conductivity. Finally such LSCF nanofibers cathode can be considered as a good platform for further microstructure optimizing, which could be a research subject with great interest.

In this chapter, LSCF nanofibers were fabricated and used as the SOFC cathode. The unit cell performance was recorded for the first time for such 1-D nanostructure cathode. Further efforts of infiltrating GDC into the LSCF nanofiber cathode were carried out and the relationship of the electrochemical performance and the microstructure was addressed. 


\subsection{Experimental Detail:}

\subsubsection{Materials Synthesis}

$6 \%$ wt of Polyacrylonitrile (PAN) was dissolved in N'N- Dimethylformamide $(\mathrm{DMF})$ at $60^{\circ} \mathrm{C}$ under stirring until a clear yellow solution formed. $\mathrm{La}\left(\mathrm{CH}_{3} \mathrm{COO}\right)_{3}$ -1.5 $\mathrm{H}_{2} \mathrm{O}, \operatorname{Sr}\left(\mathrm{CH}_{3} \mathrm{COO}\right)_{2} \bullet 0.5 \mathrm{H}_{2} \mathrm{O}, \mathrm{Co}\left(\mathrm{CH}_{3} \mathrm{COO}\right)_{2} \bullet 4 \mathrm{H}_{2} \mathrm{O}$ and $\mathrm{Fe}\left(\mathrm{CH}_{3} \mathrm{COO}\right)_{2}$ were then added into the solution in $0.58: 0.4: 0.2: 0.8$ mole ratio and stirred at $80^{\circ} \mathrm{C}$ until completely dissolved. The precursor was then loaded into a syringe mounted on a syringe pump and the electrospinning experiment was conducted at an electrical field of $1.2 \mathrm{kV} / \mathrm{cm}$ and precursor ejection rate of $0.25 \mathrm{ml} / \mathrm{hr}$. A grounded stainless steel foil was used as sample collector. The as spun fibers mats were peeled off from the collector and heated at $800^{\circ} \mathrm{C}$ to achieve the perovskite phase.

\subsubsection{Fuel Cell Fabrication and Testing}

Anode supported half cells were supplied by the Institute of Energy and Climate Research in Jülich, Germany. The trilayers structure includes a $500 \mu \mathrm{m}$ thick NiO-YSZ anode layer, a $10 \mu \mathrm{m}$ thick YSZ electrolyte layer and a 3 4 $\mu \mathrm{m}$ thick GDC buffer layer which prevents the possible interaction between LSCF and YSZ. The cell dimension is 23 $\mathrm{mm}$ by $23 \mathrm{~mm}$. The detail fabrication process can be found in Ref [5]. The LSCF nanofibers were mixed with commercial ink vehicle (IV, NexTech Materials, Ltd. Lewis Center, $\mathrm{OH}$ ) in proper weight ratio and painted on the half cell and finally sintered at $925^{\circ} \mathrm{C}$ for 3 hours to form the cathode. The activated cathode dimension is $10 \mathrm{~mm}$ by 10 $\mathrm{mm}$; the power density is calculated based on this value. The sample is denoted as LSCF NF.

For cells with GDC infiltration, a precursor was prepared by dissolving $6 \% \mathrm{wt}$ PAN, $0.4 \mathrm{M} \mathrm{Ce}\left(\mathrm{NO}_{3}\right)_{3}$ and $0.1 \mathrm{M} \mathrm{Gd}\left(\mathrm{NO}_{3}\right)_{3}$ in DMF. Then the needed amount of precursor was applied on the LSCF cathode using a precise pipette. The electrodes were then fired at $800^{\circ} \mathrm{C}$ again for 1 hour with $1{ }^{\circ} \mathrm{C} / \mathrm{min}$ rate. Cathodes with GDC mass contents of $20 \%$ and $50 \%$ were fabricated, and those samples are denoted as LSCF20GDC and LSCF50GDC. 
The unit cell was mounted on an alumina tube end and sealed by Aremco Ceramabond 552 on the edge. $3 \% \mathrm{H}_{2} \mathrm{O}$ humidified $\mathrm{H}_{2}$ and air were used as fuel and oxidant at the anode and cathode sides, respectively. Silver paste and mesh were used as the current collector. The cells were connected to Solartron 1260 potentialstat/1287 impedance analyzer using silver wires for electrochemistry characterization from $600^{\circ} \mathrm{C}$ to $800^{\circ} \mathrm{C}$ with $50^{\circ} \mathrm{C}$ interval.

\subsubsection{Materials Characterization}

The morphologies of the nanofibers and the fuel cells cathodes were examined using Hitachi S-4000 scanning electron microscopy (SEM) and FEI/Philips CM-20 transmission electron microscopy (TEM), the crystalline phase was determined by Panalytical X-ray diffractometer (XRD) equipped with a thin film stage and select area electron diffraction (SEAD). X-ray photoelectron spectroscopy (XPS) was used to examine the surface chemistry of the material. All the electrodes characterizations were performed after the electrochemistry testing.

\subsection{Results and Discussion:}

In previous chapter we have reported a reliable electrospinning method to fabricate large quality of functional metal oxide nanofibers for SOFC cathode application. Here the LSCF nanofibers are successfully fabricated as YSZ and LSM nanofibers.

The SEM images of the LSCF nanofibers after $800^{\circ} \mathrm{C}$ calcination can be found in Figure 6.1 (a) and (b). It can be seen a uniform and long nanofiber network has formed. The length of the nanofibers can reach to several tens of microns. The crystal phase of the nanofibers was confirmed by XRD. All the peaks of the spectrum in Figure 6.1 (c) can match with rhombohedral lanthanum strontium iron cobalt oxide (LSCF), which indicates the fibers have high crystalline quality. The average grain size calculated from Scherrer's equation was $\sim 40 \mathrm{~nm}$. The fibers diameter distribution was plotted in Figure 6.1 (d) based on counting 100 nanofibers, and the mean diameter is around $230 \mathrm{~nm}$. 

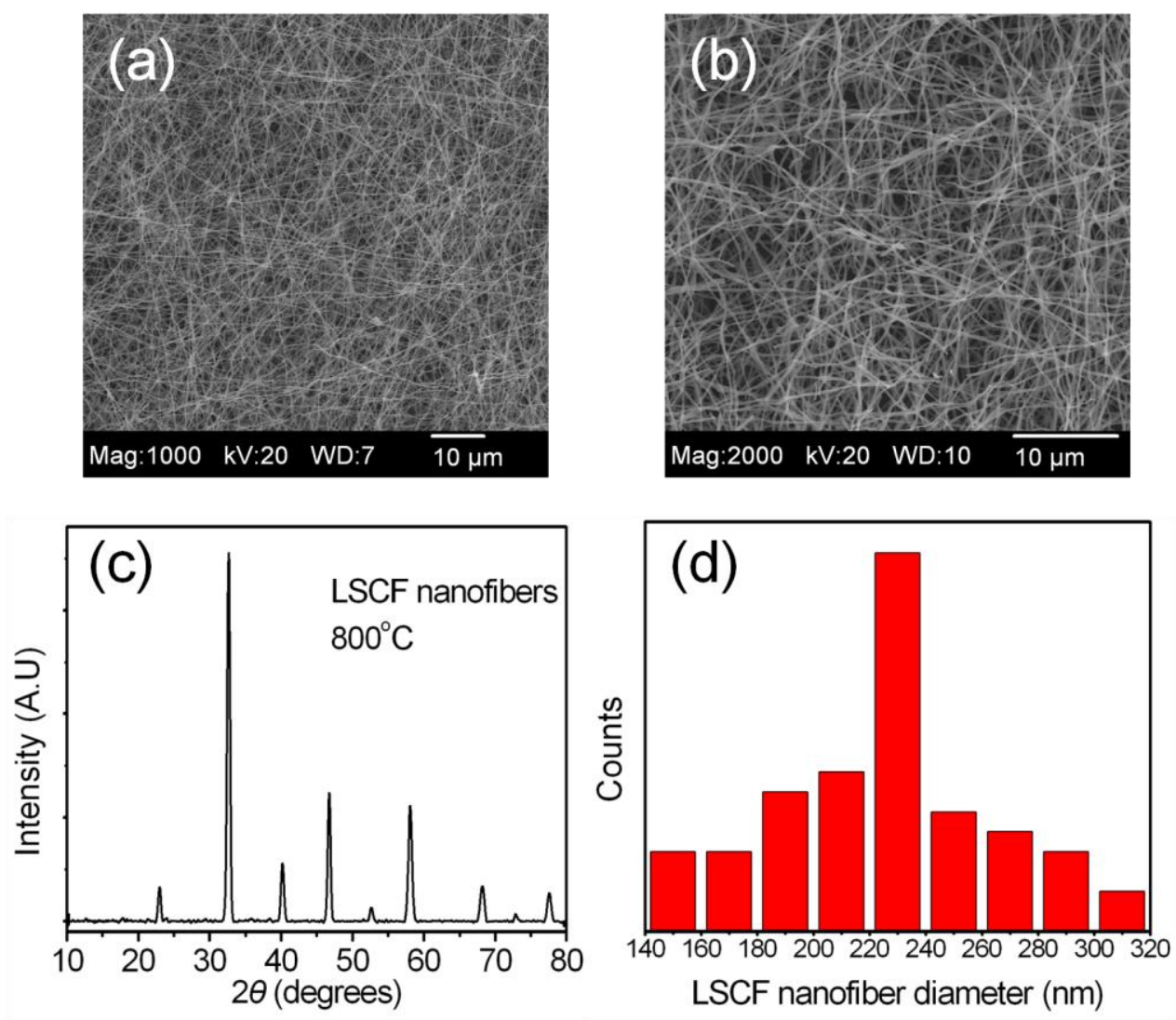

Figure 6.1 (a) and (b) SEM images of the LSCF nanofibers fired at $800^{\circ} \mathrm{C}$, (c) corresponding XRD pattern and (d) the nanofibers size distribution

TEM was used to further confirm the morphology and structure of the LSCF nanofiber. Figure 6.2 (a) shows the bright field TEM image of one single LSCF nanofiber and its corresponding SAED (selected area electron diffraction) pattern. The diameter of the fiber is around $200 \mathrm{~nm}$ and the crystal structure has been confirmed as perovskite. Fine nano grains can also be indentified with the size of $\sim 45 \mathrm{~nm}$, which is close to the data gained from XRD. An elements analysis result is shown in Figure 6.2 (b) where La, $\mathrm{Sr}, \mathrm{Fe}$ and $\mathrm{Co}$ are found which confirms the composition. 

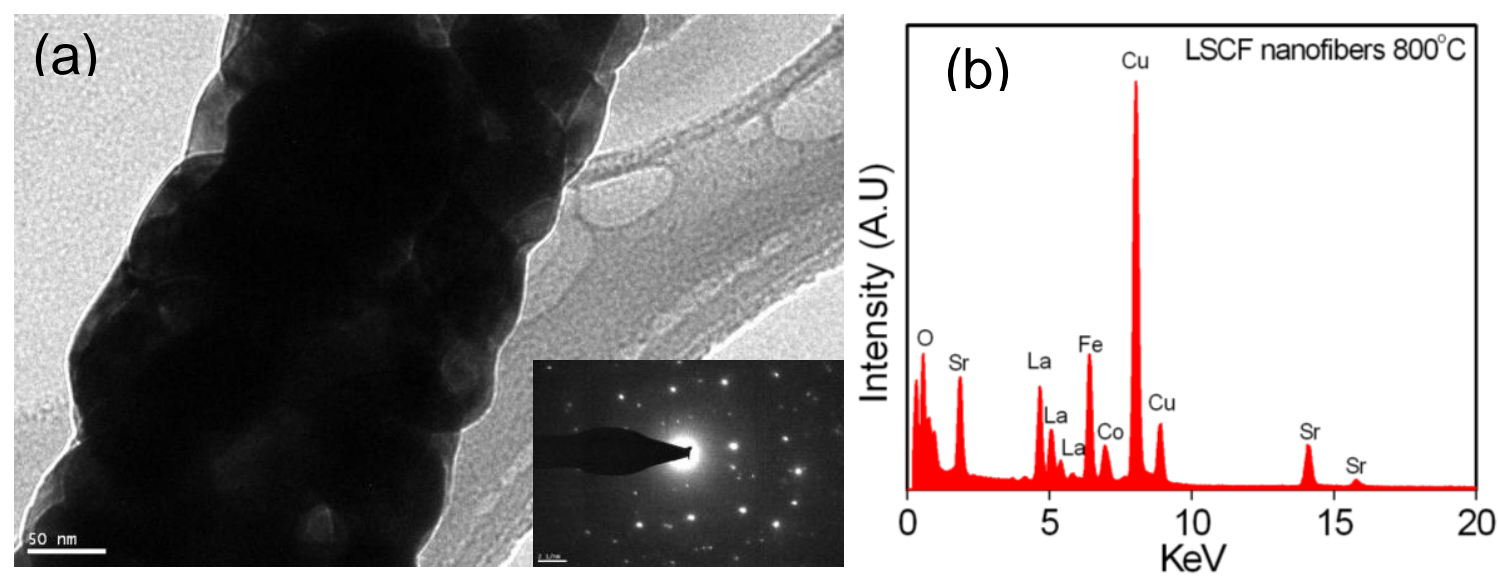

Figure 6.2 (a) TEM image of a single LSCF nanofiber and the corresponding SAED pattern (insert) and (b) EDX spectra taken from the nanofiber, the $\mathrm{Cu}$ signal came from the $\mathrm{Cu}$ grid for dispersing sample

After sintering the nanofibers on the electrolyte to form cathode and testing, the fibrous network mostly retained. Figure 6.3 (a) is the surface morphology of the cathode. The fiber mean diameter is around 240nm, which is slightly larger compared with raw fibers. Large pores in several $\mu \mathrm{m}$ scale can be found within the nanofiber network. Figure 6.3 (b) shows the cross section SEM image of the cell, from which the thickness of the cathode can be estimated as $40 \mu \mathrm{m}$. Considering a $\sim 6 \mathrm{mg} / \mathrm{cm}^{2} \mathrm{LSCF}$ loading, the porosity of the cathode can reach up to $75 \%$, which reveals a highly porous cathode has been successfully fabricated without any additional pore former or filler. It also reveals a good interconnection between the LSCF nanofiber and the GDC buffer layer is formed, which is important for achieving good cell performance. 

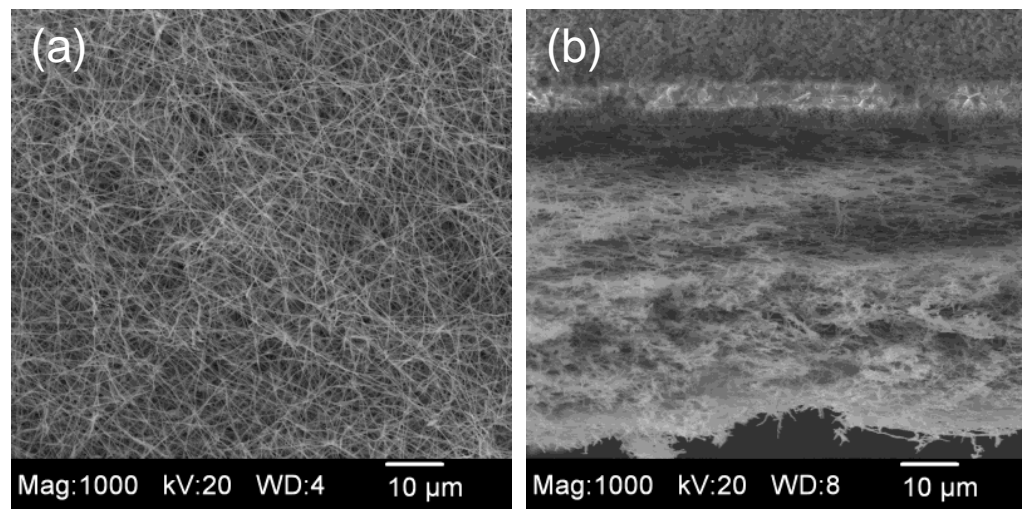

Figure 6.3: SEM images of the LSCF nanofibers cathode cell after testing, (a) the surface morphology of the cathode and (b) the cross section of the cell

Figure 6.4 (a) is the V-I curve for the cell operating from $600^{\circ} \mathrm{C}$ to $800^{\circ} \mathrm{C}$, the open circuit voltages were $1.12 \mathrm{~V}$ and $1.05 \mathrm{~V}$ at $600^{\circ} \mathrm{C}$ and $800^{\circ} \mathrm{C}$, respectively, which indicates a good sealing in the testing apparatus. The peak power density at $600^{\circ} \mathrm{C}$ is $0.27 \mathrm{~W} / \mathrm{cm}^{2}$, and eventually reached to $1.22 \mathrm{~W} / \mathrm{cm}^{2}$ at $800^{\circ} \mathrm{C}$ when the cell held at $\sim 0.60 \mathrm{~V}$. Such results are at least comparable, if not superior; to the most of the LSCF cathode based SOFC using similar configurations [5-10].

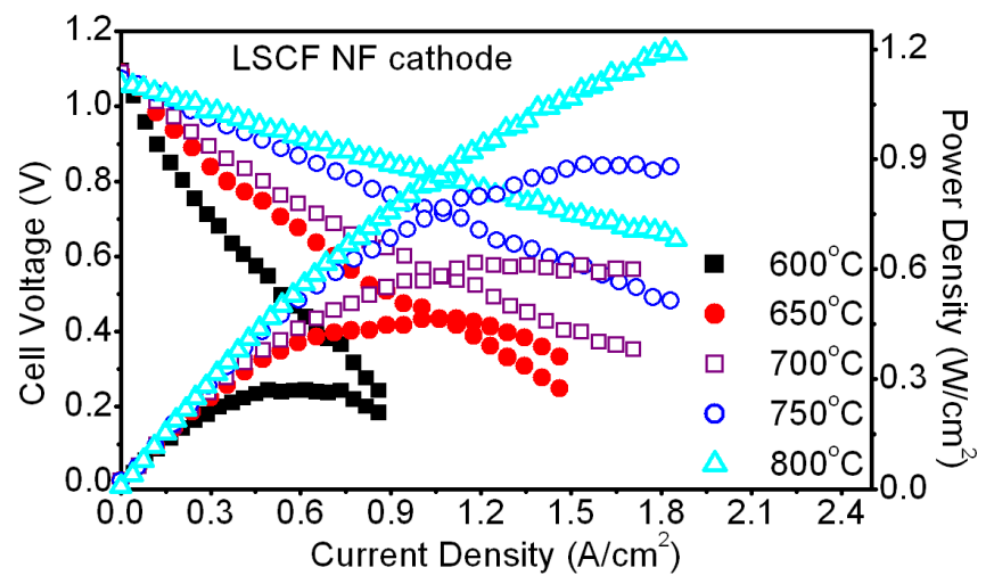

Figure 6.4: The V-I curves of the LSCF NF cell at different temperatures

The good performance of such cathode can be explained from several aspects. The nanofibers network is highly porous which facilitates the gas diffusing. The high aspect ratio $(>100)$ of the nanofiber implies a high surface area for electrochemical 
oxygen reduction reaction. The interconnected nanofibers also offers continued charge transfer pathway. Based on the percolation theory, the critical density $\mathrm{Nc}$ of the conducting stick for percolation in the random distributed network can be written $[11,12]$

$$
l \sqrt{\pi N_{c}}=4.236
$$

where $l$ is the length of the "conducting stick". Assuming the mean average length of nanofibers is $20 \mu \mathrm{m}$ from Figure 6.3 (a), a value of $\sim 1.5^{*} 10^{-2} / \mu \mathrm{m}^{2}$ can be derived for $N_{c}$, which is much less than the nanofiber density observed from the SEM image. Therefore, it can be concluded that the nanofibers network cathode is highly percolated and connected, which offers "high way" for both electrons and oxygen ions transfer. Such property is critical for maximizing the total oxygen reduction reaction sites. Besides the high porous structure and continuous charge transfer "highway" properties, the nanofiber has higher surface oxygen vacancy concentration compared with powder sample. XPS was used to examine the surface chemical status of LSCF nanofibers and nanopowders with the same formula $\mathrm{La}_{0.58} \mathrm{Sr}_{0.4} \mathrm{Co}_{0.2} \mathrm{Fe}_{0.8} \mathrm{O}_{3}$. The $\mathrm{O} 1 \mathrm{~s}$ core level scan result is shown in Figure 6.5. The spectra are fitted by 3 peaks, which representing different oxygen species. The $\mathrm{O} 1 \mathrm{~s}$ peak at $529 \sim 530 \mathrm{eV}$ can be assigned to lattice oxygen $\left(\mathrm{O}_{\text {lattice }}\right)$. The peak at $531.4 \sim 531.9 \mathrm{eV}$ is usually related to adsorbed oxygen species $\left(\mathrm{O}_{\mathrm{ad}}\right)$ including $\mathrm{O}^{-}, \mathrm{O}^{2-} \mathrm{OH}^{-}$, etc., which are believed to be mainly adsorbed on lattice oxygen vacancy sites. Such absorbed oxygen species can be easily released at high temperature to leave the oxygen vacancy free [13]. The peak near $533 \mathrm{eV}$ is attributed to $\mathrm{H}_{2} \mathrm{O}$ molecules adsorbed on the material surface [14]. The ratio of $\mathrm{O}_{\mathrm{ad}} / \mathrm{O}_{\text {lattice }}$ of nanofiber and nanopowders are 0.28 and 0.19 , respectively, which indicates more active oxygen vacancy can be formed at fuel cell testing condition. Those vacancies can promote the oxygen reduction reaction as well as increase the oxygen ion conductivity, which offers the nanofibers as a superior electrochemical catalyst. Such finding may be attributed to more exposed grain boundary on nanofibers surface, where the defects are preferred to aggregate. 


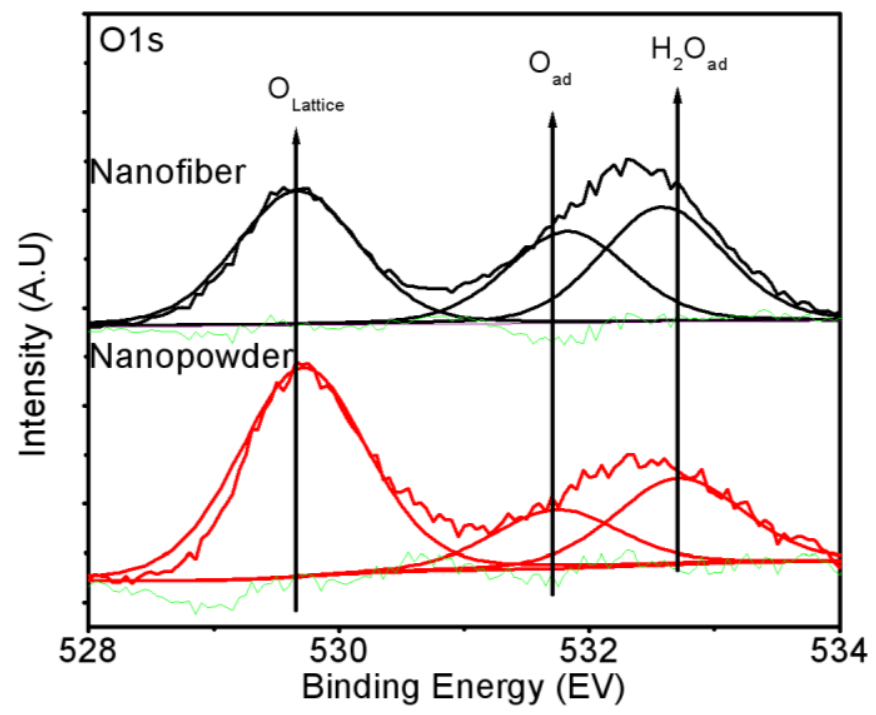

Figure 6.5 The XPS O1s core level of the LSCF nanofibers and nanopowders

Infiltration method was employed in order to further improve the cell performance. It has been reported that adding GDC to LSCF can significantly reduce the polarization resistance of the electrode up to one order of magnitude [15]. The optimized GDC ratio is between $36 \% \sim 60 \%$ in mass depending on the microstructures and fabrication process $[16,17]$. The ionic conductivity of GDC is $2-3$ orders higher than LSCF [14]; therefore the additional GDC can form a secondary oxygen ion pathway in the cathode. The additional GDC can also tune the thermal expansion coefficient of the electrode to promote the sintering ability $[18,19]$. Figure 6.6 shows the cells V-I curves with $20 \%$ and $50 \%$ mass of GDC infiltrated in cathode. It can be seen the power densities of the LSCF20GDC cell at different shown improvement compared with the pure LSCF $\mathrm{NF}$ cell. The peak power density is $0.31 \mathrm{~W} / \mathrm{cm}^{2}$ and $1.33 \mathrm{~W} / \mathrm{cm}^{2}$ at $600^{\circ} \mathrm{C}$ and $800^{\circ} \mathrm{C}$, respectively. When at $750^{\circ} \mathrm{C}$, a $1.07 \mathrm{~W} / \mathrm{cm}^{2}$ power density (at $1.9 \mathrm{~A} / \mathrm{cm}^{2}$ ) is about $18 \%$ greater compared with LSCFNF cell $\left(0.90 \mathrm{~W} / \mathrm{cm}^{2}\right.$, at $\left.1.9 \mathrm{~A} / \mathrm{cm}^{2}\right)$, which indicates the $20 \%$ mass GDC infiltration could greatly improve the nanofiber cathode, especially at the intermediate temperature. When the GDC amount increased to 50\%, performance degradation was found compared with pure nanofiber cell. A $0.98 \mathrm{~W} / \mathrm{cm}^{2}$ power density at $1.9 \mathrm{~A} / \mathrm{cm}^{2}$ was recorded at $800^{\circ} \mathrm{C}$, which is $\sim 20 \%$ lower than the LSCF NF cell. 

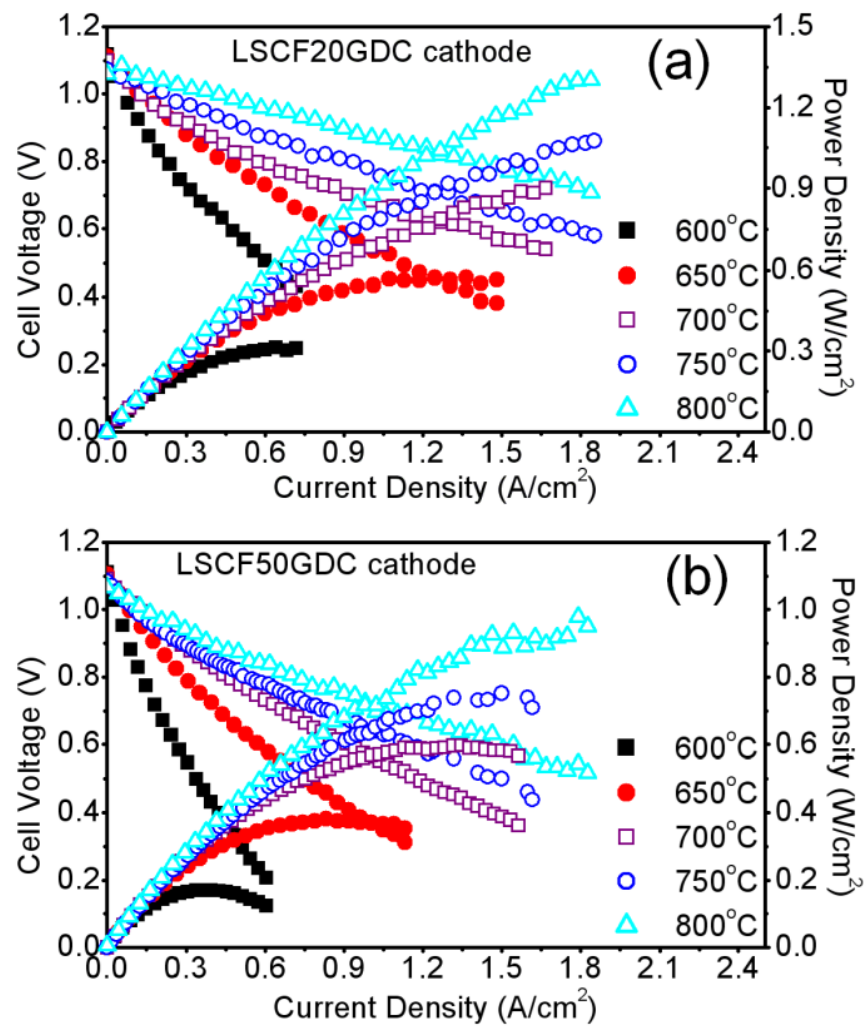

Figure 6.6 The V-I curves of the LSCFGDC20 (a) and LSCFGDC50 (b) cells at different temperatures

Considering the identical anode and electrolyte used in the experiments, it is likely that the different performance is originated from the cathode side. The surface morphologies of the LSCF20GDC and LSCF50GDC cell cathodes can be found at Figure 6.7 It is found that $20 \%$ mass GDC addition didn't change the fiber length significantly, as large area of long nanofiber network still existed. Higher magnification SEM image reveals the fiber diameter $(340 \mathrm{~nm})$ increased compared with that in the LSCFNF cathode, which indicates a coating of GDC on the LSCF surface. In some area connected GDC aggregates can be found but most of the nanofibers are still well apart. Such observation implies the GDC precursor is preferred coating on the LSCF nanofibers rather than forming membranes between the fibers. However in the LSCF50GDC cathode, it is found the fiber length decreased dramatically, with most of them are around 5-10 $\mu \mathrm{m}$. In addition, many of the fibers are embedded in large GDC aggregates. This is consisted with the fact that more GDC was infiltrated. The shortening of the nanofiber can be explained by the thick GDC coating. The CTE mismatch between LSCF and GDC caused 
additional stress on the nanofiber, so most of the fibers may break into short segments. The long range charge transfer advantages brought by nanofibers therefore became weak. The thick coating may also block the gas/catalyst interface, which inhabits the catalysis reaction. The surface porosity is also reduced for the LSCF50GDC cathode compared with the other two as can be seen in Figure 6.4 and Figure 6.7, which is caused by the over loaded GDC materials. Such microstructure change can explain the performance retardation of the LSCFGDC50 cell. In the meantime, for the LSCFGDC20 cathode, the long nanofiber was retained, which ensures the long range electron transport capability and high porosity, the additional GDC improves the oxygen ion conductivity of the overall cathode so a performance enhancement is observed. Therefore it can be conclude that for the tested 3 types of cathodes, a 20\%wt of GDC adding is the most optimized structure.
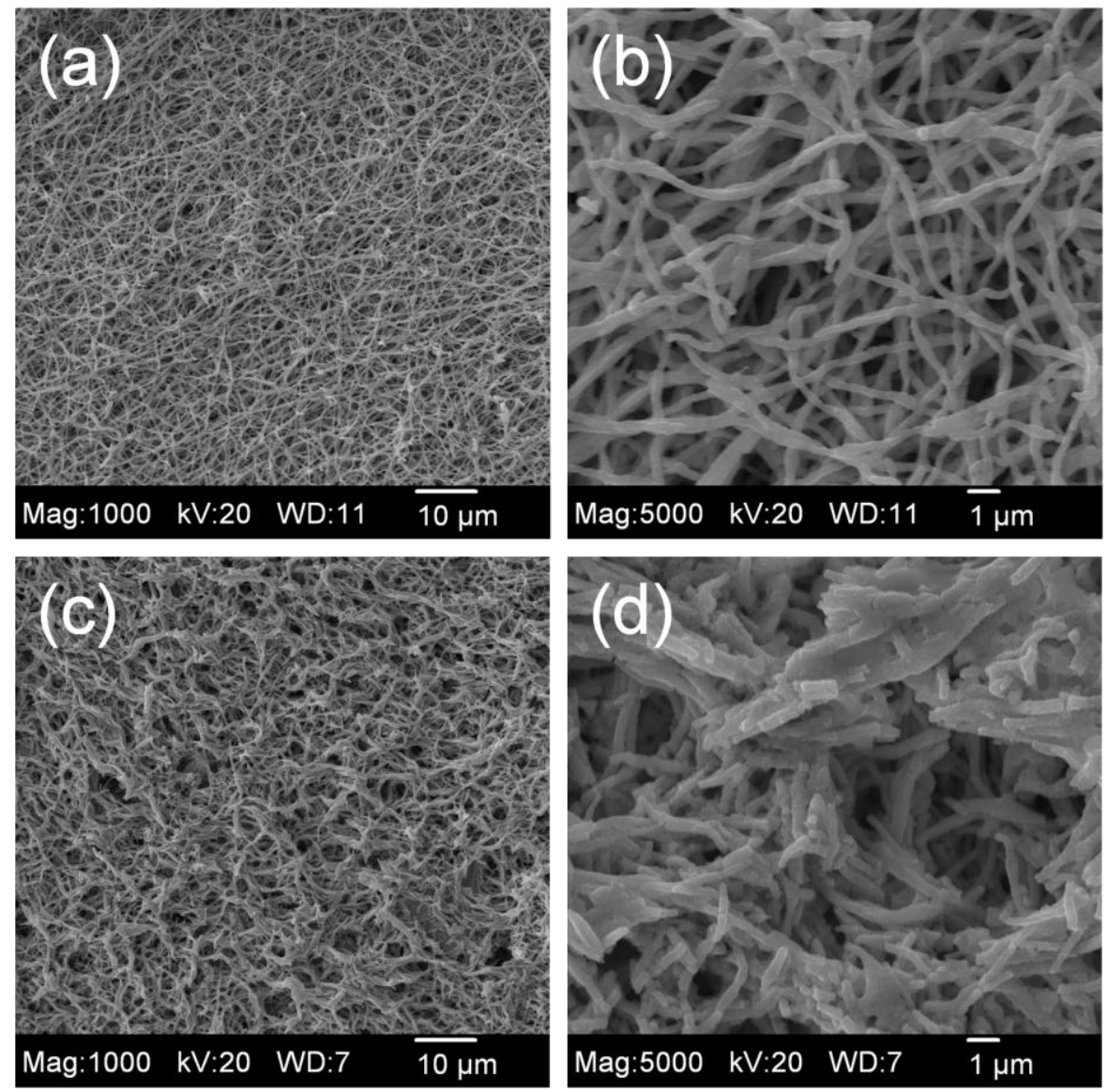

Figure 6.7 SEM images of the surface morphology of the LSCF/GDC cathodes, (a) and (b): LSCF20GDC cathode; (c) and (d); LSCF50GDC cathode 
XRD was further used to characterize the cathode crystal structures shown in Figure 6.8. It is found only LSCF and GDC peaks were found after testing, the peak ratio of the compounds is well consistent with the designing. Such result shows there is no interaction of the LSCF and GDC during the testing and confirms the structure integrity of the cathode.

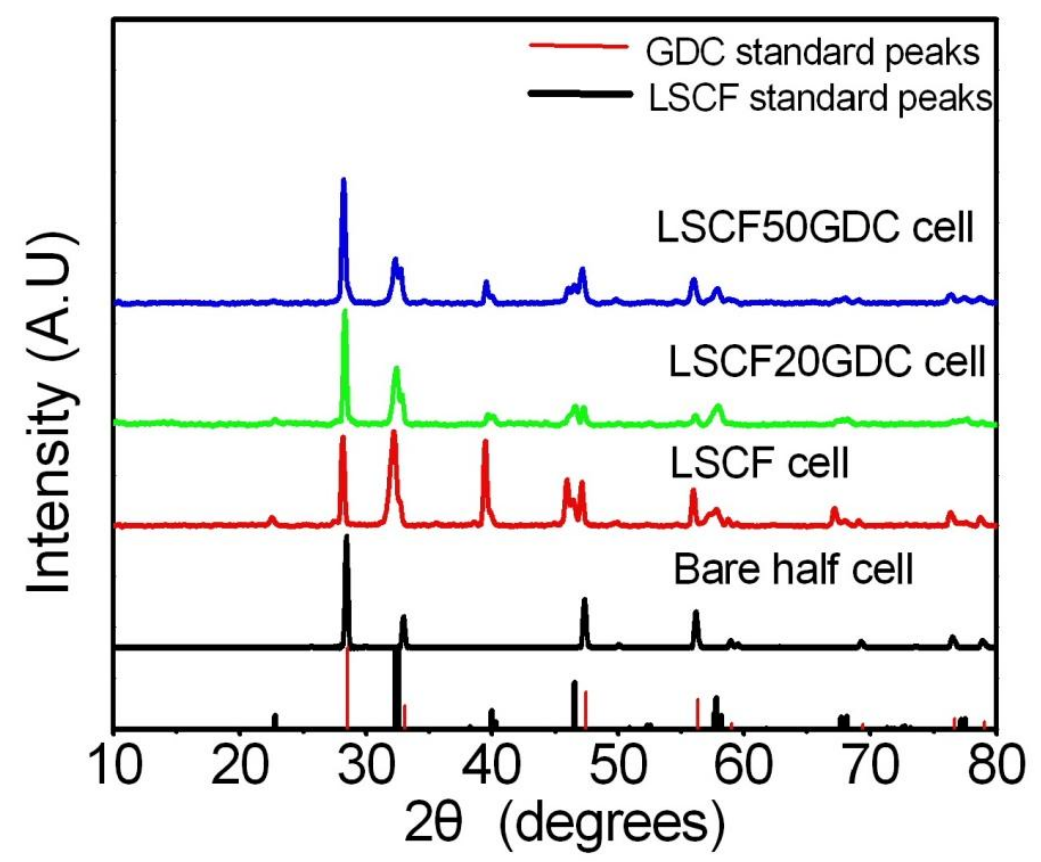

Figure 6.8 XRD patterns of the fuel cells taken at the cathode side after testing

\subsection{Conclusion:}

For the first time, SOFC with LSCF nanofiber based cathode were fabricated. Such nanofiber architecture is stable at high temperature. Acceptable performance at intermediate temperature range was reached. The power density can reach 0.90 and 1.22 $\mathrm{W} / \mathrm{cm}^{2}$ at $750^{\circ} \mathrm{C}$ and $800^{\circ} \mathrm{C}$, respectively. With additional $20 \%$ GDC infiltration in the cathode, the cell power density can reach 1.07 and $1.33 \mathrm{~W} / \mathrm{cm}^{2}$ at $750^{\circ} \mathrm{C}$ and $800^{\circ} \mathrm{C}$. Higher loading of GDC (50\%) caused performance degradation, which can be explained as a destruction of the continued nanofiber network. 


\section{References for Chapter 6:}

[1] S. B. Adler, Chem. Rev., 104, 2004, 4791

[2] S. P. Simner, J. P. Shelton, M. D. Anderson and J. W. Stevenson, Solid State Ionics, $161,2003,11$

[3] Y. K. Tao, J. Shao, W. G. Wang and J. X. Wang, Fuel Cells, 5, 2009, 679

[4] T. Suzuki, Z.Hasan, Y. Funahashi, T. Yamaguchi, Y. Fujishiro and M. Awano, Science, 14, 2009, 852

[5] F.C. Fonseca, S. Uhlenbruck, R. Nedéléc and H. P. Buchkremer, J. Power Sources, $195,2010,1595$

[6] N. Jordan , W. Assenmacher, S. Uhlenbruck , V.A.C. Haanappel, H.P. Buchkremer, D. Stöver and W. Mader, Solid State Ionics, 179, 2008, 919

[7] S. P. Simner, M. D. Anderson, M. H. Engelhard and J. W. Stevenson, Electrochemical and Solid-State Letters, 9, 2006, A478

[8] W. Zhou, Z. P. Shao, R. Ran, H. X. Gu, W. Q. Jin and N. P. Xu, J. Am. Ceram. Soc., $91,2008,1155$

[9] Y. Sakito, A. Hirano, N. Imanishi, Y. Takeda, O. Yamamoto and Y. Liu, J. Power Sources, 182, 2008, 478

[10] Y. Sakitou, A. Hirano, N. Imanishi, Y. Takeda,Y. Liu and M. Mori, Journal of Fuel Cell Science and Technology, 5, 2008, 031207

[11] L. Hu, D. S. Hecht, and G. Gru1ner, Nano Letters, 4, 2004, 2513

[12] H Wu, L. B. Hu, M. W. Rowell, D. S. Kong, J. J. Cha, J. R. McDonough, J. Zhu, Y. Yang, M. D. McGehee, and Y Cui, Nano Letters, 10, 2010, 4242

[13] J. Deng, L. Zhang, H. Dai, H. He and C. T. Au, J. Mol. Catal. A: Chem., 2009, 299, 60 
[14] M. Zhi, G. Zhou, Z. Hong, J. Wang, R. Gemmen, K. Gerdes, A. Manivannan, D. Ma and N. Q. Wu, DOI:10.1039/c0ee00300j

[15] I. Kim, S. Barnett, Y. Jiang, M. Pillai, N. McDonald, D. Gostovic, Z. Zhan and J Liu, Final Report to DOE Award DE-FC26-02NT41570

[16] H. J. Hwang, J. W. Moon, S. Lee and E. A Lee, J. Power Sources, 145, 2005, 243

[17] H. Huang, T. M. Gür, Y. Saito, and F. Prinz, Appl. Phys. Lett., 89, 2006, 143107

[18] A. Mai, V. A. C. Haanappel, S. Uhlenbruck, F. Tietz and D. Stover, Solid State Ionics, 176, 2005, 1341

[19] Y. J. Leng, S. H. Chan and Q. Liu, Int. J. Hydrogen Energy., 33, 2008, 3308 


\section{Chapter 7: Conclusion and Future Work}

\subsection{Conclusions:}

1. The degradation behavior of the Ni-YSZ anode in $\mathrm{PH}_{3}$ contained coal syngas was studied. It is found most $\mathrm{PH}_{3}$ could be converted to $\mathrm{P}_{2} \mathrm{O}_{3}$ because the $\mathrm{H}_{2} \mathrm{O}$ presented in the syngas. Ni phosphate was the product of reaction between $\mathrm{Ni}$ and $\mathrm{P}_{2} \mathrm{O}_{3}$, which caused the electrode lose the electrochemical activity and electron conductivity. Surface reconstruction phenomenon related $\mathrm{Ni}-\mathrm{P}$ diffusion to the anode surface was reported. Impedance spectra were fitted with equivalent circuits. The mass diffusion resistance increased faster than the charge transfer resistance. High temperature/High PH3 concentration as well as the electrical bias will accelerate the degradation.

2. Electrospinning method is used to fabricate nanofiber materials for SOFC cathode application. Such nanofibers include YSZ, LSM, and LSCF etc, which are structurllystable at high temperature.

3. LSM/YSZ composite cathode was fabricated by infiltrating LSM into YSZ nanofibers scaffold, such cathode showed superior performance compared with conventional powder cathode.

4. SOFC with LSCF nanofiber cathode was constructed and showed good performance at intermediate temperature range $\left(<800^{\circ} \mathrm{C}\right)$. Further infiltrating GDC with controlled amount can improve the performance of such cathode. 


\subsection{Future Work:}

Further researches are suggested based on the present result:

1. Comprehensive study of the degradation of Ni-YSZ anode in trace impurities of coal syngas is needed. Such study should be focused on the correction of the microstructure change and the electrochemical performance degradation. Many issues are still not clear, for examples, the surface reconstruction of the Ni-YSZ in $\mathrm{PH}_{3}$ impurity, the origin of the effect of the electrical bias etc. Fundamental research is needed for further understanding such phenomenon.

2. In Chapter 4, a reliable electrospinning method for synthesizing nanofibers is demonstrated. It is worthy to further investigate the experimental parameters in order to control the nanofiber morphology such as composition, diameter etc. It will be also more interesting to develop composite nanofibers with complex structure, such as core-shell fiber for maximizing the TPB sites.

3. Good performance of the nanofibers based cathode have already been shown, however more fundamental knowledge needs to be grained for further improving the microstructure. Electrode 3-D reconstruction technology could offer valuable information about the active sites, the porosity etc. More nanofiber based cathodes with different materials combinations are needed to be tested and compared in order to achieve better performance. 


\section{Appendix:}

Author's publication list during Ph.D study

Peer-Reviewed Journal Papers:

1. M. Zhi, X. Chen, H. Finklea, I. Celik, and N.Q. Wu, Electrochemical and Microstructural Analysis of Ni-Yttria Stabilized Zirconia Electrode Operated in Phosphorus-Containing Syngas, J. Power Sources, 183, (2008), 485-490.

2. F. N. Cayan, M. Zhi, S. R. Pakalapati, I. Celik, N. Q. Wu, and R. Gemmen, Effects of Coal Syngas Impurities on Anodes of Solid Oxide Fuel Cells: a Review, J. Power Sources, 185 (2008), 595-602.

3. J. Wang, D. N. Tafen, J. P. Lewis, Z. Hong, A. Manivannan, M. Zhi, M. Li, and N.Q. Wu, Origin of the Photocatalytic Activity of Nitrogen-doped $\mathrm{TiO}_{2}$ Nanobelts, Journal of the American Chemical Society, 131 (2009), 12290-12227.

4. M. Zhi, F. N. Cayan, I. Celik, R. Gemmen, S. R. Pakalapati and N. Q. Wu, Temperature and Impurity Concentration Effects on Degradation of Nickel/Yttriastabilized Zirconia Anode in $\mathrm{PH}_{3}$-Containing Coal Syngas, Fuel Cells, 10 (2010), 174-180.

5. M. Zhi, G. Zhou, Z. Hong, J. Wang, R. Gemmen, K. Gerdes, A. Manivannan, D. Ma and N. Q. Wu, Single Crystalline $\mathrm{La}_{0.5} \mathrm{Sr}_{0.5} \mathrm{MnO}_{3}$ Microcubes as Cathode of Solid Oxide Fuel Cell, Energy \& Environmental Science, 4 (2011), 139-144.

6. M. Zhi, N. Mariani, R. Gemmen, K. Gerdes, and N. Q. Wu, Nanofiber Scaffold for Cathode of Solid Oxide Fuel Cells, Energy \& Environmental Science, 4 (2011), 417-420. 
7. M. Zhi, et al, High Performance Solid Oxide Fuel Cell Utilizing LSCF Nanofibers Cathode, in preparation.

\section{Conference Papers:}

1. M. Zhi, N. Madhiri, H. Finklea, I. Celik, B. Kang, X. Liu, R. Bajura, and N.Q. Wu, Impedance Analysis of Phosphorous Impurity Effect on Performance of NiYSZ Anode of SOFC, Electrochemical Society Transaction, 11 (2008),71-77

2. J. Wang, M. Li, M. Zhi, A. Manivannan, and N.Q. Wu, Hydrothermal synthesis and photocatalytic activity of titanium dioxide nanotubes, nanowires and nanospheres, Mater. Res. Soc. Symp. Proc. 1144 (2009), LL07-08.

\section{Presentations:}

1 M. Zhi and N.Q. Wu, Impedance Analysis of Phosphorous Impurity Effect on Performance of Ni-YSZ Anode of SOFC, 212th Electrochemical Society Meeting, 2007, Washington, DC.

2 M. Zhi and N.Q. Wu, Degradation of Solid Oxide Fuel Cell Anode in Phosphorous-Containing Syngas, 2008 Materials Research Society Fall Meeting, Boston, MA.

3 M. Zhi and N.Q. Wu, Study on the Solid Oxide Fuel Cell Electrodes, WVNano Brown Bag Lunch Series Seminar, 2010, Morgantown, WV.

4 M. Zhi and N.Q. Wu, Degradation Behaviors of Solid Oxide Fuel Cell Anode in Phosphorous-Containing Syngas, 218th Electrochemical Society Meeting, 2010, Las Vegas, NV. 


\section{Posters:}

1. M. Zhi and N.Q. Wu, Degradation of Solid Oxide Fuel Cell Anode in Phosphorous-Containing Syngas, U.S Army Portable Energy System Symposium, 2008, College Park, MD.

2 M. Zhi and N.Q. Wu, Electrospun Functional Ceramic Nanofibers, WV Nano Annual Symposium, 2009, Morgantown, WV.

3 M. Zhi and N.Q. Wu, Electrochemical Oxygen Reduction Properties of LSM Microcubes, 2009 Materials Research Society Fall Meeting, Boston, MA.

4 M. Zhi, N. Mariani and N.Q. Wu, YSZ Nanofiber Scaffold for Cathode of Solid Oxide Fuel Cells, 218th Electrochemical Society Meeting, 2010, Las Vegas, NV. 